\title{
INFORMATIONS TECHNIQUES
}

\section{Deuxième cours sur le diagnostic de la peste bovine}

\author{
(Laboratoire de Farcha 10-15 juin 1963)
}

En mai 1961, la C.C.T. A., qui comprend, entre autres, la Fondation pour l'Assistance Mutuelle en Afrique (F. A. M. A.) et le Bureau interafricain pour la santé animale (I. B. A. H.) suscita à Kano (Nigeria) une importante conférence qui étudia les moyens de réaliser une campagne d'éradication de la peste bovine sur le territoire des Etats du Cameroun, du Niger, de la Nigeria et du Tchad.

Ce projet, classique dans sa conception, renforce les actions des Services de l'Elevage des Etats intéressés grâce aux importants moyens que l'A. I. D. et la C. E. E. mettent à leur disposition par le canal de la C. C. T. A.

En principe sont menées de front :

- la vaccination antipestıque systématique et contrôlée du cheptel bovin,

- I'harmonisation des législations sanıtaires,

- la coercition immédiate des contrevenants grâce à une procédure d'urgence et expéditive, laxie.

- la progression des recherches scientifiques sur le diagnostic de la peste bovine et sa prophy-

Un premier cours sur le diagnostic de la peste bovıne, s'est déroulé en 1961 au laboratoire de Muguga (Nairobi-Kenya), le second, en 1963 à Fort-Lamy. Les conférences et travaux pratiques ont eu lieu au laborataire de recherches vétérinaires de Farcha dont la gestion a été confiée à l'Institut d'Elevage et de Médecine vétérinaire des Pays tropicaux. Ce cours se plaçait sous l'égide de la F.A.M. A. et était organisé par l'institut. Il s'est déroulé, sous la direction de M. THOME, directeur régional de I'I. E. M.V.T. Conférences et manipulations furent assurées en anglais et en français par MM. PROVOST et BORREDON.

Si nous publions aujourd'hui le texte des exposés qui ont été faits, c'est qu'il nous a semblé que Jes vétérinaires qui travaillent sur le terrain à lutter contre la peste bovine y trouveraient des méthodes utilisables dans les conditions pratiques de la brousse. Mais nous tenons cependant à préciser que les méthodes expérimentales qui sont décrites doivent être considérées comme des moyens complémentaires de diagnostic ef ne prétendent pas se substifuer aux méthodes classiques de la clinique et de Tépizootiologie. 


\title{
Les différents aspects du diagnostic clinique et expérimental de la peste bovine
}

\author{
por A. PROVOST ef C. BORREDON
}

\begin{abstract}
AVANT-PROPOS
Nous n'avons pas la prétention, dans l'exposé qui va suivre, de faire preuve d'originalité. C'est. une compilation en langue française de travaux épars dans la littérature, assortie de réflexions venant de notre expérience personnelle. Les techniques décrites ont en effet été essayées et «radées» à Farcha depuis 1955 ; nous avons fait un tri, parmı toutes celles qui ont été proposées, pour ne retenir que celles qui nous paraissaient les plus simples d'exécution et les mieux adaptées aux conditions tropicales. Nous avons eu le souci constant, dans la description des méthodes de diagnastic, de nous placer à la portée du vétérinaire de brousse et du laboratoire régional, souvent dépourvus de moyens techniques du dernier cri mais forts de leur bonne volonté. C'est pour eux, et pour l'cuure d'éradication de la peste bovine du continent africain à laquelle ils se sont vovés, que ces lignes ont été écrites. Puissent-elles remplir leur but, c'est notre souhait.
\end{abstract}

Nous remercions la Revue Veterinary Medecine ainsi que l'American Veierinary Medical Association d'avoir bien voulu nous autoriser à reproduire des illustrations déjà publiées

Le Professeur F. K. RAMSEY, lowa state University, Ames, et le Docteur MACKOWIACK, de I'I. F. F. A., ont eu I'amabilité de nous communiquer leurs clichés origınaux.

Enfin la Revue Deutsche Tierärtztliche Wochenschrift a bien voulu nous prêler ses typons.

A tous nous adressons nos sincères remerciements.

Rev. Elev. Méd. vét. Pays trop., 1963, 16, no 4. 


\title{
TABLE DES MATIÈRES
}

\author{
Avant-propos
}

Première partie

\section{DIFFICULTÉS ACTUELLES D'UN DIAGNOSTIC DE CERTITUDE DE LA PESTE BOVINE.}

I. Peste bovine $\ll$ historique $»$ et peste actuelle $\ldots \ldots \ldots \ldots \ldots \ldots \ldots \ldots \ldots \ldots \ldots \ldots \ldots, 449$

II. Le nouveau visage de la peste . . . . . . . . . . . . . . . . . . . . . . . . . . . . . 449

chez les bovins. 1. Aspect épizootiologique ............................ 449

2. Aspects cliniques ............................. 450

3. Les facteurs en cause .......................... 450

le bétail ................................ 451

le virus ... . . ......................... 451

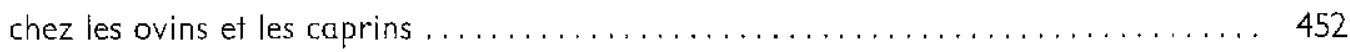

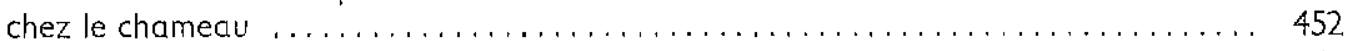

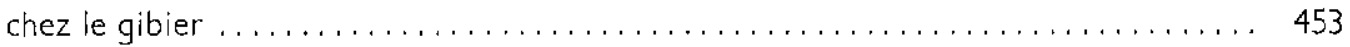

III. Les maladies « pestiformes $» \ldots \ldots \ldots \ldots \ldots \ldots \ldots \ldots \ldots \ldots \ldots \ldots \ldots \ldots \ldots \ldots \ldots \ldots \ldots \ldots$

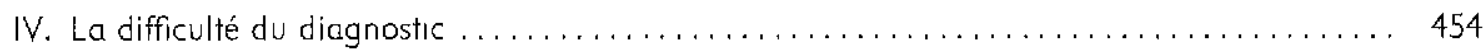

\section{Seconde partie}

\section{DIAGNOSTIC CLINIQUE DIFFÉRENTIEL DE LA PESTE BOVINE ET DES MALADIES ATTEI- GNANT LES MUQUEUSES.}

Maladie cliniquement semblable à la peste bovine. - L'entérite à virus . . . . . . . . 455

Affections atteignant la muqueuse buccale $\ldots \ldots \ldots \ldots \ldots \ldots \ldots \ldots \ldots \ldots \ldots \ldots$. . . . . . . . . . . 461

1. La fièvre aphteuse .................................. 461

2. La stomatite vésiculeuse . . . . . . . . . . . . . . . . . . . . . . . . . . . 463

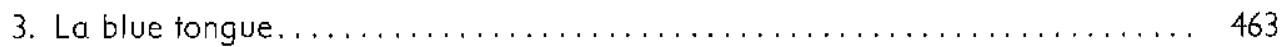

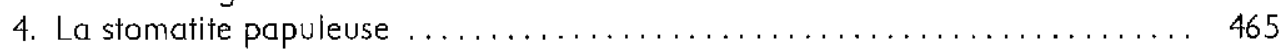

5. La diphtérie des veaux ou nécrobacillose .................... 465

6. Stomatites diverses $\ldots \ldots \ldots \ldots \ldots \ldots \ldots \ldots \ldots \ldots \ldots \ldots \ldots \ldots, \ldots \ldots \ldots$

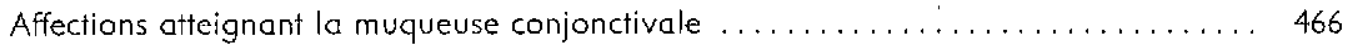

Affections atteignant les muqueuses respiratores $\ldots \ldots \ldots \ldots \ldots \ldots \ldots \ldots \ldots \ldots$

1. La rhinotrachéite bovine infectieuse $\ldots \ldots \ldots \ldots \ldots \ldots \ldots \ldots, \ldots \ldots 6$

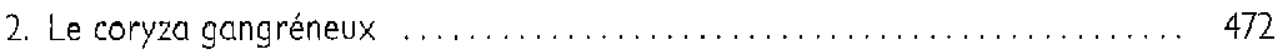

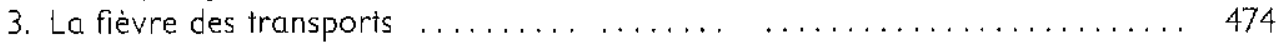


Affections touchant la muqueuse de la caillette $\ldots \ldots \ldots \ldots \ldots \ldots \ldots \ldots \ldots \ldots, 474$

Affections touchant la muqueuse intestinale $\ldots \ldots \ldots \ldots \ldots \ldots \ldots \ldots \ldots \ldots$

Troisième parfie

\section{DIAGNOSTIC EXPÉRIMENTAL DE LA PESTE BOVINE}

I. Diagnostıc histologıque ....................................... 476

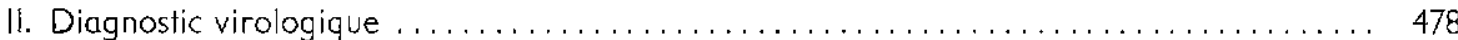

A. Reproduction de la maladie $\ldots \ldots \ldots \ldots \ldots \ldots \ldots \ldots \ldots \ldots \ldots \ldots \ldots \ldots \ldots$

B. Isolement ef identification du virus en cultures cellulaires ............... 480

III. Diagnostic sérologique $\ldots \ldots \ldots \ldots \ldots \ldots \ldots \ldots \ldots \ldots \ldots \ldots \ldots \ldots \ldots \ldots \ldots \ldots \ldots \ldots \ldots$

Rappels préliminaires $\ldots \ldots \ldots \ldots \ldots \ldots \ldots \ldots \ldots \ldots \ldots \ldots \ldots \ldots \ldots \ldots \ldots, 481$

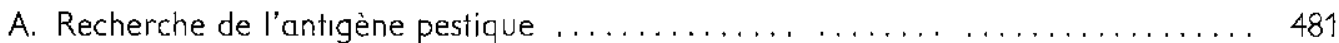

précipitation-diffusion en gélose $\ldots \ldots \ldots \ldots \ldots \ldots \ldots \ldots \ldots \ldots \ldots \ldots \ldots, 481$

déviation $d u$ complément . ............................... 482

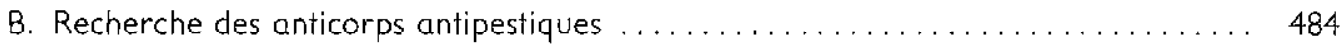

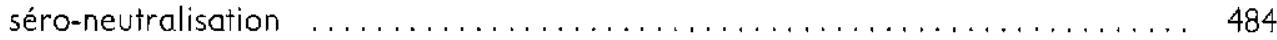

\section{Quatrième partie}

\section{LA CONDUITE DU DIAGNOSTIC - CHOIX D'UNE MÉTHODE}

\section{FICHES TECHNIQUES}

Fiche technique $n^{0} 1$. Modèle de fiche de renseignements

- $\quad-\quad n^{\circ} 2$. Prélèvements à faire en vue d'un diagnostic histologique de peste bovine.

- - n $\quad$ 3. Méthodologie des prélèvements pour diagnostic de la peste bovine par culture cellulaire

Fiche technique $n^{0} 4$. La séro-neutralisation $\ldots \ldots \ldots \ldots \ldots \ldots \ldots \ldots \ldots \ldots \ldots \ldots \ldots \ldots \ldots$

— pour l'identification du virus ........................ 491

- pour la recherche des anticorps ..................... 493

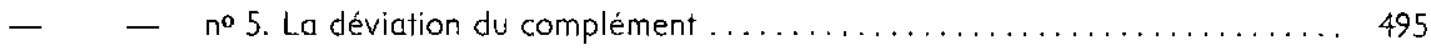

A — Mise en évidence de l'antigène .................... 495

- technique de Nakamura ....................... 495

- - de Boulanger ...................... 499

- $\quad$ - de Cowan ......................... 500

- _ de Stone et Moulton .................. 502

B - Mise en évidence des anticorps.................... 505

- $\quad$ - $\quad n^{0} 6$. La réaction de précipitation en gélose $\ldots \ldots \ldots \ldots \ldots \ldots \ldots \ldots \ldots \ldots \ldots$

- préparation des antigènes de référence ................. 506

- préparation du sérum précipitant....................... 509

- préparation de la gélase ........................... 515

- préparation des antigènes suspects $\ldots \ldots \ldots \ldots \ldots \ldots \ldots \ldots \ldots \ldots, 516$

- exécution du test .................................. 517

- $\quad$ - $\quad \pi^{0} 7$. Méthodologie des prélèvements de sérum pour diagnostıc rétrospectif de

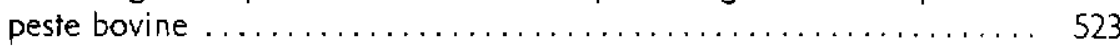

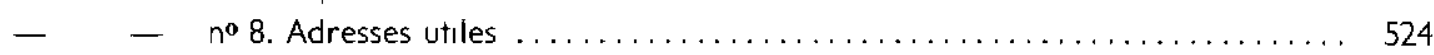

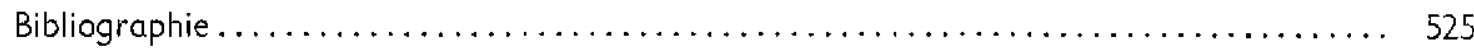




\section{Ire PARTIE}

\section{DifFICULTÉS ACT UELLES D'UN DIAGNOSTIC DE CERTIT UDE DE LA PESTE BOVINE}

\section{I. - PESTE « HISTORIQUE» ET PESTE « ACTUELLE» *}

DIX lustres avant que ces lignes ne soient écrites, ces titres eussent paru insolites. Pour NOCARD ef LECLAINCHE, pour ROBERT KOCH, pour THEILER, en ne citant que ces auteurs et sans vouloir remonter le cours du temps, le diagnostic clinique ou nécropsique de la peste bovine s'établissaił d'emblée et ne prêtaıt pas à discussion. Il s'imposait par la reconnaissance de l'extension du contage, la clinique et les lésions caractéristiques sur les bovins malades, eł par une mortalité extrêmement importante.

Peu de données devaient être ajoutées à ces éléments du diagnostic par CURASSON, par DAUBNEY et par JACOTOT, et l'on peut dire que jusqu'à ces dernières années, rien n'était modifié quant à la relative facilité du diagnostic du typhus bovin.

Mass, comme d'autres maladies animales, la peste bovıne a changé de visage. La grande peste africaine des années 1890-1900 est de nos jours une peste «historique ». Si, pendant cette période, plus de 90 p. 100 du bétail d'Afrique noire fut tué par la maladie classique telle que l'ont décrite les auteurs, on ne peut citer durant ces dernières années que deux épizooties, heureusement limitées dans leur extension par des circonstances géographıques, qui ont présenté so gravité et ses caractères : ce sont celle de l'Adamaoua au Cameroun en 1960 et celle de la province d'Equateur au Congo en 1961. Là, la morbidité fut de près de 100 p. 100 et la mortalité de 85 à 90 p. 100 avant l'intervention sanitare.

En dehors de ces deux exemples, la peste historıque n'est plus rencontrée de nos jours en Afrique noire. Il s'y est substitué une peste «atypique » que nous qualifierons plus volontiers «d'actuelle». Ce n'est pas brusquement toutefois, que ses manifestations ont supplanté celles de la peste classique. Dès 1935 existait dans le centre africain une peste à symptomatologie particulière qu'a décrite RECEVEUR (1937). Elle est maintenant la plus commune. Nous la commenterons brièvement.

\section{II. - Le nOUVEAU VISAge DE LA PESTE BOVINE \\ CHEZ LES BOVINS}

\section{Aspect épizootiologique.}

Les jeunes de 6 à 14 mois sont le plus souvent atfeints et il est fréquent pour ne pas direconstant, de ne voir que des animaux de ce groupe d'âge malades dans un troupeau ; les veaux plus jeunes, les onimaux plus vieux, sont épargnés.

Des bovins plus âgés (2 à 3 ans, voire des adulfes) peuvent également contracter la peste ; mais ces animaux se rencontrent dans des régions très particulières, soit d'accès difficile incitant les vétérinaires à une action réservée (montagnes de l'Ennedı et îles du Lac Tchad), soit infectées de glossines ; les vaccinations sont alors mises en œuvre avec prudence par crainte de réactions vaccinales par

* : Les opinions émises et les indications proposées sont spécıalement valables pour les zones occidentales el centrales du continent africain. (Note des auteurs) 
trop fâcheuses (région de la Bénové au Cameroun). Sur ces bovins d'âge plus avancé, l'expression clinique de la peste est plus franche que sur les jeunes.

Limitée à un groupe d'âge, la peste bovine l'est également dans son extensıon. Les épizooties dévastatrices sont du domaine du passé. Les foyers sont sporadiques, évoluant dans un troupeau, gagnant les troupeaux immédiatement voisins où en général seuls les jeunes sont touchés. La situation sanitaire est depuis deux lustres quelque peu comparable à celle de la fièvre aphteuse en Europe lors des périodes d'interépizooties.

Ce tableau très général ne voudrait cependant pas être exclusif. Il arrive que des symptômes pestiformes soient relevés sur des bovins adultes. Il est vraisemblable qu'il s'agit souvent de peste, surtout si ces animaux vivent dans un foyer, mais nous verrons en abordant le diagnostic clinique combien it convient en fait d'être prudent en posant de nos jours un diagnostic de peste bovine sur le bétail adulte vivant en régions vaccınées.

Différent est par contre le problème que posent les enclaves non vaccinées jouxtant les territoires infectés: Adamaoua au Cameroun, Républıque Centrafricaine. Une incursion dévastatrice de peste y est toujours à redouter, témoin celle de 1960 en Adamaoua. En ces circonstances, le caractère envahissant du typhus bovin se retrouve en entier.

\section{Aspects cliniques.}

II est malaisé de systématiser les différentes formes, intriquées les unes dans les autres. On peut néanmoins citer :

- les pestes d incubation langue, de 25 à 40 jours, d'observation courante au Tchad. La notion de contamination est alors particulièrement difficile à établir.

- les formes apyrétiques : les lésions buccales apparaissent, la diarrhée s'installe puis survient la mort dans un laps de temps assez bref. La température ne s'élève pas au-dessus de 3805-3808 C. Cette forme est extrêmement fréquente dans te centre africain.

- les formes « eutrophiques»: la prostration qui est classique et a permis de donner le nom de typhus bovin à la peste, ne se manifeste guère chez les jeunes. Jusqu'à la morf l'animal conserve son habitus normal. II mange jusqu'à la dernière extrêmité et il n'est pas rare de trouver des cadavres qui gardent serrés entre leurs machoires les derniers brins de paille qu'a broutés l'animal avant sa mort.

- les formes nan ulcératives. Les lésions buccales n'apparaissent pas. La diarrhée s'établit, l'animal se cachectise et meurt dans le marasme. Ce sont des formes relativement fréquentes au laboratoire. En d'autres circonstances, la santé revient après cessation de la diarrhée.

- les formes amyotrophiques, caractérisées par une diarrhée profuse et une fonte musculaire spectaculaire du train postérieur, croupe et cuisse.

- les formes nerveuses, à vrai dire extrêmement rares, avec mouvement de tournis, attitudes anormales, mugissements et parfois fureur ; elles semblent être dues d̀ une piroplasmose, à une heartwater (ou à une theileriose, là où celle-ci existe) concomitantes;

- les formes pulmonares ont été signalées récemment en Egypte : hyperthermie, légère diarrhée, larmoiement et écoulement nasal, toux rauque. A l'autopsie, on ne constate qu'une pneumonie lobaire apicale avec une légère gastro-entérite et émaciation musculaire. Ces lésions en imposent pour le diagnostic de fièvre des transports mais l'isolement du virus prouve qu'il s'agit du virus bovipestique.

- les formes lentes (plutôt que chroniques), avec poussées thermiques fugaces qu'accompagnent des épisodes diarrhéiques et des accidents congestifs. Après quelques récurrences espacées de périodes de 15 à 20 jours, la constipation succède à la diarrhée. La guérison intervient souvent mais amène toujours un amaigrissement de l'animal ququel il sera très difficile de faire reprendre de l'état.

\section{Les facteurs en cause.}

Comme toutes les maladies virales, la peste bovine se joue à deux partenaires : le bétail d'un côté, le virus d'un autre. Tous deux ont leurs implications dans cette peste actuelle. 


\section{a) Le facteur bétail.}

\section{Efat immunitaire}

La grande majorité (90 p. 100 au moins) du bétail des régions où la peste est encore généralement considérée comme enzootique, est immune de peste par l'un ou l'autre des 3 processus suivants :

- Immunité naturelle qui a suivi une attaque plus ou moins violente de la maladie naturelle dans le passé.

- Immunité vaccinale, conférée par l'un des virus-vaccins, généralement aussi solide que la première quoique d'une durée moindre en ce qui concerne le virus-vacan lapinisé.

- Immunité colostrale, transmise par la mère immune (naturellement ou par vaccination) à son veau. If a été démontré que les anticorps présents dans le colostrum (et non dans le lait) étaient absorbés par l'intestin du veau nouvecu-né à jeun et qu'après cette première tétée le taux d'anticorps du veau, nul à la naissance, égalait celui de sa mère.

Ces anticorps persistent chez le vecu jusqu'à l'âge de 10 mois mais ne s'opposent victorieusement à l'infection pestique (naturelle ou vaccinale) que jusqu'à l'âge moyen de 6 mois *.

On a ainsi l'explication du schéma épizootiologique évoqué plus haut : population adulte (audessus de 18 mois) immune, veaux sous leurs mères immuns, jeunes sevrés réceptifs parce qu'ayant perdu leur immunité colostrale et non encore vaccinés car les campagnes de vaccınation sont annuelles.

Si cet état immunitaire particulier du troupeau africain explique l'épizootiologie nouvelle de la peste sur ce contınent, il n'en est pas moins important de souligner que la réceptivité au virus (sauvage, capripestique ou lapinisé) du veau qui a perdu ses anticorps colostraux est pleine et entière : témoins en sont les réactions vaccinales parfois violentes sur les jeunes de 12 à 14 mois qui suivent la vaccination au virus capripestique.

$2^{\circ}$ étot nutritionnel et hormonal

La réceptivité immunologique est une chose, la « réactivité » de l'organisme bovin à l'agression virale en est une autre. On sait qu'une part importante de la symptomatologie d'une maladie infectieuse est jouée par la réaction d'alarme déclanchée par le complexe neuro-surrénalien. Cette réaction sous la dépendance d'une décharge de glycocorticoldes, se caractérise notamment par une exacerbation de la fièvre, l'apparition de la congestion dans divers parenchymes.

C'est par ailleurs une notion de pathologie générale classique que les signes cliniques d'une infection virale sont mieux extériorisés chez les sujets pléthoriques que chez les sujets cachectiques. Or les veaux sevrés sont sous-alimentés parce que leur sevrage intervient fréquemment pendant la saison sèche, ef de surcroît parasités par toute une gamme de nématodes et des cestodes. Leur organisme est en état d'hypofonctionnement surrénalien, ce qui entraîne une réduction des réactions inflammatoires virales non spécifiques (corigestion, certaines ulcérations) et de l'hyperthermie.

\section{b) Le facteur virus.}

L'unicité immunologique du virus bovipestique ne saurait être mise en doute ; le virus est antigéniquement le même qu'il soit isolé au Viet-Nam, au Kenya ou au Tchad. Mais il est sur qu'il existe foute une gamme de pouvoir pothogène dons les souches souvoges. Cefte variation du comportement du virus a été longtemps suspectée mais ce n'est qu'assez récemment qu'elle a été mise en évidence.

Faisant suite aux observations de LOWE (1947) qui avait décrit une souche naturellement atténuée chez le bétail, ROBSON (1959) a isolé au Tanganyika une souche pestique chez l'élan. Inoculée à des zébus pleinement sensibles, originaires de zones non contaminées, non vaccinés et vierges de tout anticorps, elle n'a donné lieu qu'à une montée thermique sans lésıons buccales, ni diarrhée : la guérison est intervenue rapidement. Passée sur du bétal de type européen, elle déterminait une

* Des observations faites au Tchad montrent que le veau recouvre d'abard sa sensibılıté au virus pesilique sauvage avant de recouvrer celle au virus capripestique. 
stomatite, un peu de dıarrhée, qucune mortalité. Les passages en série n'augmentalent pas le pouvoir pathogène du virus.

Sept autres souches se comportant de la même manière et ayant la caractéristique essentielle de ne pas déterminer de diarrhée et d'être non léthales, viennent d'être éłudiées par PLOWRIGHT (1963) en Afrique orientale.

Ces faits extrêmement probants démontrent la plasticité du virus. On peut se demander par quel mécanisme un virus pleinement virulent ḋ l'origine se transforme ainsı en virus peu pathogène. L'opinion de RECEVEUR (1951) qui supposait une transformation du virus évoluant sur un bétal semi-immun est très plausible. C'est ce même phénomène qui a été invoqué pour la transformation du virus pestique en celui de la peste des petits ruminants par adaptation à des races caprines peu sensibles (MORNET, ORUE, ef GILBERT, 1956). Nous avons nous-mêmes observé au laboratore une transformation du virus capripestique qui, par passages sur des chèvres résistantes, devenait extrêmement pathogène pour la chèvre et inactif chez les bovins.

Ainsi comprend-on l'apporition d'une symptomatologie bâtarde de la peste bovine chez les jeunes : des virus à pouvoir pathogène amoindri infectent des veaux pouvant encore posséder un état immunitaire résiduel et déséquilibrés surrénaliens. L'expression clınique du typhus s'en trouve perturbée chez le malade ef l'extension de la maladie freinée dans le troupeau.

La question de plasticité du virus pose un problème difficile pour le diagnostic car NAKAMURA a montré que le développement de l'antigène déviant le complément dans les ganglions lymphatiques des bovins inoculés reflétait le pouvorr pathogène de la souche. Or nous verrons plus loin que l'antigène déviant le complément et le précipitogène sont étroitement apparentés sinan semblables, si bien qu'une incertitude règne actuellement sur la possibilité de diagnostic de ces souches pestiques hypo-virulentes pour le bétail par la méthode de précipitation en gélose.

Un intérêf certain s'aftache d̀ la reconnaissance de ces pestes atypiques, que cefte «atypie» ait pour origine un état immunitaire particulier du bétail ou une hypo-virulence du virus. En effet troublantes par leur symptomatologie, elles peuvent faure aiguiller le diagnostic de peste sur une autre voie, avec le corollaire de la non-intervention sanitare alors que subsiste le danger potentiel d'une résurgence explosive de la virulence du contage.

La sagesse veut donc que même pour un diagnostic clınique incertain, on prenne toutes mesures utiles en attendant sa confirmation qu'apportera le diagnostic expérimental.

\section{CHEZ LES OVINS ET LES CAPRINS}

La réceptivité expérimentale des petits ruminants domestiques africains est un fait établi, mais jusqu'à ces années dernières, on ne connaissait que deux épizooties authentiques en Afrique de peste bovine naturelle sur de petits ruminants (en Egypte en 1893, en Afrique du Sud vers 1894).

Cependant, en 1957 un foyer de peste bovine est apparu sur des moutons à Vom en Nigeria. Le transport du contage a été assuré par des bovins qui ont infecté les moutons de race locale. La symptomatologie chez les moutons se manifestait spécialement par une diarrhée et un jetage muco-purulent. Des guérisons ont eu lieu.

En 1958, la peste fut reconnue sur les chevreaux en Ouganda. La maladie était sub-clinique. Une enquête sérologique montra, par l'importance des sujets présentant des antıcorps, que la maladie était enzootique.

Est-ce que, comme le suggère DAUBNEY (1949), la peste est en extension sur les petits ruminants? Les seules observations sont incapables d'y répondre mais elles ont le mérite d'attirer l'attention pour les années d̀ venır.

\section{CHEZ LE CHAMEAU}

La peste bovine naturelle chez le chameau n'a jamais été constatée avec certifude en Afrique. Une étude récente de SCOTT et Mac DONALD (1962) montre que les chameaux vivant dans les 
régions traversées par la vague épizootique de 1960 au Kenya n'ont jomais été malades et ne présentent pas d'anticorps. C'est pouvoir affirmer l'ınsensibilité du dromadaire à la peste bovine naturelle, mettant le point final à une longue controverse.

\section{CHEZ LE GIBIER}

Les données connues 's'applıquent surtout à l'Áfrique orientale, où les grandes antilopes et les buffles sont tenus pour responsables de la pérennité de la survivance du contage dans la nature, alors que les gazelles se montrent très résistantes à la peste.

Une enquête sérologique effectuée au Kenya et au Tanganyika, a démontré que le schéma immunologique des groupes d'âge (adultes naturellement immuns et jeunes bénéficiant de l'immunité colostrale) était valable pour le gnou (espèce non représentée en Afrique centrale et occidentale) et le buffle. II semble démontré (PLOWRIGHT, 1963) que des souches de virus pestique, stabilisées dans leur hypovirulence, infectent sans discrimination grandes antilopes, bovins et buffles, espèce chez laquelle les signes cliniques sont les plus sévères. Le danger représenté par la coexistence du gibier et du bétail est donc double : l'un est le réservoir de virus pour l'autre, réservoir de virus particulièrement inquiétant parce que ne donnant que des maladies larvées et pouvant prêter à la confusion clinique.

En dehors de cette enquête aucun fait nouveau saillant en ce domaine ne s'est fait jour ces années dernières en Afrique centrale et occidentale. Les troupeaux de grandes antilopes ne s'y rencontrent pas par centaines de milliers comme elles existent en Afrique orientale, où ils pacagent mêlés aux bovins. C'est pour cette raison qu'on doit toujours considérer comme vraie l'opinion de RECEVEUR (1954) selon laquelle dans le reste de l'Afrique le gibier n'est pas un réservoir de virus pour le bétail. mais que l'inverse (avant l'introduction des campagnes de vaccination massive) était exact.

En ces contrées, la disparition de la peste sur les bovins devrait entraîner sa disparition sur le gibier.

En conciusion de cette brève revue clinique, nous ne saurions trop insister sur l'intérêt qu'il y a pour le succès des campagnes de vaccination, à reconnaître la peste bovine dans sa nouvelle expression clinıque et épizootiologique, car les aspects peuvent en être trompeurs. L'attention devra également être attirée sur la possibilité d'infection des petits ruminants avec des souches adaptées à ces espèces.

\section{III. - LES MALADIES « PESTIFORMES »}

A côté des formes déroutantes que peut présenter la peste bovine, s'est fait jour une pathologie nouvelle, tout au moins dans sa reconnaissance clinique et virologique; ses manıfestations peuvent passer pour de la peste. Depuis 1947, un groupe de maladies connues en langue anglase sous le nom de «Mucosal Disease complex, »ce que l'on traduit inélégamment en français par maladies des muqueuses, a été successivement décrit en Amérıque du Nord, en Suède, en Angleterre, en Allemagne, en Australie, en France et tout récemment enfin en Afrıque.

Y sont rangées l'entérite à virus et la rhinotrachéite bovine infectieuse, toutes deux viroses spécifiques de l'espèce bovine. Le coryza gangréneux peut à bon droit y être également inclus.

Frappantes dans leurs analogies cliniques avec la peste, touchant le même groupe d'âge que celui où se rencontre la peste bovine actuelle, ces maladies viennent sıngulièrement compliquer le diagnostic. La simple reconnaissance d'ulcères buccaux qu'accompagne une dysenterie n'autorise plus à afficher l'étiquette de peste sur un malade. Il nous faudra donc étudier en détail le diagnostıc différentiel du typhus bovin, de ces maladies atteignant les muqueuses et des quelques autres affections qui s'en rapprochent.

II semble, certes, que la fréquence de ces affections ne soit pas à l'heure actuelle particulièrement élevée en Afrique tropicale. Néanmoins l'expérience américaine a enseıgné que leur importance était en fait insoupçonnée avant qu'on les découvrit. On doił se demander d'autre part, sı, sur le continent africain, ce qui fut autrefors dıagnostiqué comme étant des foyers sporadiques de peste 
bovine n'était pas en fait l'une de ces affections des muqueuses. C'est ainsi qu'en 1914-1915, MONTGOMERY fut amené à étudier au Kenya unevirose transmissible du bœuf, évoluant avec les caractères d'une peste d'une gravité moyenne sur des bovins vaccinés ou non contre la peste. Les travaux ne furent jamais repris, mais il est vraisemblable que l'auteur anglais eut affaire à une mucosal disease et que le continent africain est depuis longtemps infecté. La prudence et la rigueur diagnostique imposent donc de ne pas les négliger à l'avenir *.

\section{IV. - LA DIFFICULTÉ DU DIAGNOSTIC}

L'épizootiologie et la clinique trompeuse de la peste bovine, l'existence de «maladies des muqueuses » ne sont pas une vue de l'esprit en Afrique centrale. Ce que nous venons d'exposer, c'est la pratique qui nous l'a dicté. Depuis plus de trois ans il est malaisé, dans le bassin du lac Tchad, de poser avec certitude un diagnostic clinique de peste bovıne : tantôt on note sur quelques veaux non vaccinés des épisodes congestifs et diarrhéiques frustres, sans ulcérations buccales; tantôt au contraire, ce sont des taureaux ou de vieılles vaches, vaccinés plusieurs fois au virus-vaccin capripestique, qui présentent ulcérations buccales et diarrhée fusante.

Cette épizootiologie et cette symptomatologie aberrantes nous ont inquiétés au début, car mettant en cause la valeur de la vaccination capripestique, intrigués ensuite lorsque nous en avons abordé l'étiologie.

C'est ainsi que nous avons été amenés à explorer les méthodes précises du diagnostıc expérimental, les confrontant aux données de la clinique. Le résultat en a été l'isolement de plusieurs souches hypovirulentes de virus bovipestique sauvage chez des veaux et la reconnaissance clinique, puis virologique, de l'existence de la rhinotrachéite bovine et de l'entérite à virus.

C'est le fruit de notre expérience qui sera exposé maintenant d'une manière synthétique.

* Les virus viennent d'être isolés et authentifiés en Afrique centrale (Nole des auteurs). 


\section{2e PARTIE}

\section{DIAGNOSTIC CLINIQ UE DIFfÉRENTIEL DE LA PESTE BOVINE ET DES MALADIES ATTEIGNANT LES MUQUEUSES}

Ce n'est que pour mémoire que nous rappellerons l'évolution de la peste chez le bovin malade:

- phase d'invasion avec hyperthermie et un larmoiement discret.

- phase des lésions externes, avec initialement la congestion des muqueuses externes, qui se couvrent de foyers punctiformes blanc-grisâtres se transformant ensuite en ulcères, tandis que s'intensifient le larmoiement et le jetage qui deviennent peu à peu muco-purulents.

- phase gastro-intestinale, marquée essentiellement par la diarrhée souvent sanglante, au cours de laquelle l'état général s'altère profondément, amenant la mort en hypothermie et dans un état semi-comateux.

Sur le cadavre, on est frappé par la congestion des muqueuses du tractus digestif, les hémorragies qui s'y sont produites, accompagnées d'ulcérations dans la cavité buccale, la caillette, le cæcum et le colon. Les ganglions iymphatiques apparaissent congestionnés à la coupe.

Le diagnostic clinique et nécropsique se basant sur l'aspect des muqueuses du tube digestif, accessoirement sur cetui des muqueuses conjonctivales et nasales, c'est sur ce plan que nous bâtirons le diagnostic clinique différentiel de la peste bovine et des maladies qui peuvent lui ressembler ou qui touchent peu ou prou les mêmes muqueuses qu'elie. Nous insisterons particulièrement sur les maladies classées dans le groupe des mucosal diseases dont nous ferons de courtes monographies.

\section{A. - MALADIE CLINIQUEMENT SEMBLABLE A LA PESTE BOVINE L'ENTÉRITE A VIRUS (Virus Diarrheo)}

C'est une maladıe aiguë et subaigue, infectieuse, virulente, inoculable, propre à l'espèce bovine et due à la présence dans l'organisme d'un virus spécifique découvert en 1946 par OLAFSON, MAC CALLUM et FOX. Elle est caractérisée cliniquement par de la fièvre et une diarrhée profuse, et anatomiquement par des lésıons congestives et ulcératives des muqueuses du tractus digestif, de la leucopénie et une hypertrophie des ganglions lymphatiques.

Historique et aire géographique. - En 1946, OLAFSON et ses collaborateurs décrivaient dans l'état de New-York une maladie contagieuse qui ressemblait étrangement, à la mortalité près, à la peste bovine. Des épreuves d'immunité croisée devaient rapidement lever le doute, mais l'alerte avait été chaude... Aucun germe visible n'étant présent, la maladie était rapportée comme étant due à un ultra-virus et les auteurs proposaient le nom de «Virus Diarrhea ».

Ce syndrome entéritique était quelque temps plus tard décrit dans d'autres états d'Amérique du Nord (Maine, Colorodo, Indiana), puis en Angleterre, en Suède, en Allemagne, en France et en Australie. SCOTT et BROWN ont fort opportunément rapporté en 1957. l'étude faite par MONTGOMERY en 1914-1915 au Kenya sur une maladie bovine ressemblant à la peste et évoluant sur du bétail immun de cette dernière maladıe. De son côté, OTTE a décrit des affections cliniquement sımılares en Ethiopie et au Soudan. Elles sont suspectées en inde. GILLESPIE d'une part, KNASSIEFF d'autre part, montrèrent que le virus de l'entérite à virus est sérologiquement analogue à celui d'une autre maladie bovine décrite dans l'lowa sous le nom de Mucosal Disease. Séparées cliniquement au début, ıl est certain maintenant que les deux affections entrent dans le même groupe nosologique ; il n'y a entre 
l'entérite à virus et la Mucosal Disease qu'une question d'intensité des symptômes qu'expliquent des facteurs écologiques ef raciaux différents.

Tout dernièrement enfin, deux groupes de chercheurs, l'un de Weybridge (Angleterre), l'autre de I'Université Cornell à New-York, ont rapproché le virus de l'entérite à virus de celui de la peste porcine : les deux virus ont des propriétés antigéniques communes et immunisent réciproquement l'un contre l'autre.

Maladie à l'origine américaine, l'entérite à virus voit donc son aire géographique singulıèrement élargie ; sans beaucoup se tromper, on peut affirmer qu'elle est répartie dans le monde entier. L'isolement du virus reste à faire sur le continent africain, mais on peut être persuadé que ce n'est plus qu'une affaire de quelques mois.

Espèces affectées. - Dans les condıtions naturelles, l'entérite à virus semble être une maladie spécifique des bovins, mais on l'a également authentifiée aux Etats-Unis sur des daims. II est donc possible qu'on puisse la rencontrer un jour chez les antılapes africaines.

Expérimentalement, le virus est infectieux pour le mouton, le jeune porc et le lapin. Une souche atténuée par passage chez ce rongeur a été utilisée comme vaccin.

Epizootiologie. - L'affection sévit en général sous une allure enzootique à la fin de l'hiver ou au printemps. Elle touche une exploitation, atteint les voisines, mais prend exceptionnellement un caractère explosif. La morbidité atteint 80 p. 100 des effectifs ; la mortalité varie suivant les régions de 5 à 50 p. 100 des malades. Il semble que les bouvillons de un à deux ans soient plus volontiers atteints : la maladie est plus rare sur les veaux non sevrés. Les races à viande enfin se montrent plus réceptives que les laitières, observation toutefois plus relative qu'absolue.

Virologie. - Nos connaissances sont encore peu avancées. Le virus de l'entérite à virus * est filtrable et ultracentrifugeable (80-90 unités Svedberg) ; il a une forme sphérique ef mesure 40 millimicrons. II contient un acide ribonucléique et est inactivé par l'éther et le chloroforme, comme le sont ordinairement les lipovirus.

Sa résistance au froid est élevée. II est détruit à $56^{\circ} \mathrm{C}$ pendant 180 minutes, mais résiste à cette température pendant 30,60 et 90 minutes. L'acidification du milieu à $\mathrm{pH}: 1,3$ pendant 1 heure à $25^{\circ} \mathrm{C}$ n'a pas d'effet sur sa virulence, mais l'alcalinisation le détruit. II, est inactivé par le formol à 2 p.100. II n'hémadsorbe pas les hématies de cobayes.

Cette fiche, encore trop incomplète, ne permet pas de le classer dans un groupe de virus.

Lo culture du virus se réalise : In vivo par inoculation intraveineuse à un veau de matériel virulent et en récoltant la rate à l'acmé de la réaction thermique.

In vitro sur couches monocellulaires de cultures de rein de veau; certaines souches se montrent cytopathogènes (vacuolisation en fines bulles du cytoplasme), d'autres ne le sont pas. Les titres en virus varient de $10^{5}$ à $10^{7}$ unités virulentes par $\mathrm{ml}$. Il est vraisemblable que le virus produit un interféron. La souche «Oregon C $24 \mathrm{~V}$ » est la plus communément employée pour la régularité de son action. Pathogène pour le veau à l'isolement et lors des premiers passages, le virus s'est atténué par 31 passages en série sur cellules embryonnaires bovines et peut être utilisé comme vaccin.

Le pouvoir pathogène du virus n'est patent que pour les bovins. Ceux de 8 à 24 mois sont les plus sensibles, et encore ne le sont-ils pas tous tant semblent être répandus le virus ef l'immunité colostrale et naturelle qui en résultent. La production expérimentale de la maladie dans l'intégrité de son expression clinique est difficile : seules la fièvre diphasique et la leucopénie sont constantes, tandis que l'apparition de la diarrhée ef l'inflammation des muqueuses visibles sont plus rares ef sous la dépendance de facteurs encore inconnus.

Le lapin inoculé par voie veineuse, sans développement d'aucun trouble, conserve le virus vivant dans sa rate, ce qui permet de reproduire la maladie chez le veau. Soıxante-quinze passages en série atténuent le virus.

* en abrégé : Virus VD. 


\section{PLANCHE I. - ENTÉRITE A VIRUS}

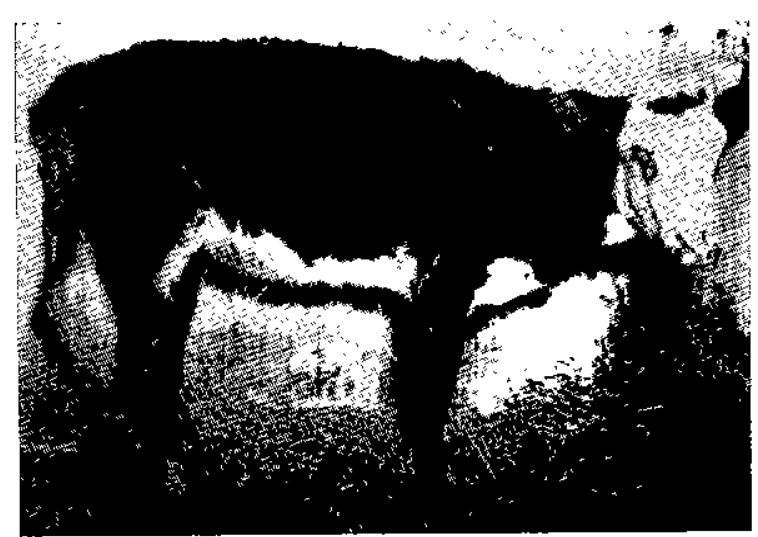

Photo 1. - Aspect « pestique » d'un veau malade.

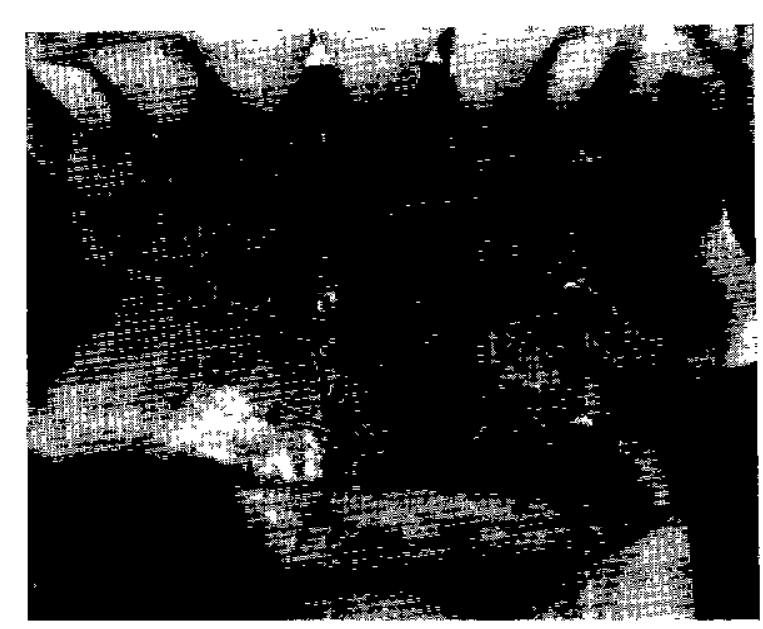

Photo 3. - Ulcérations gingivales.

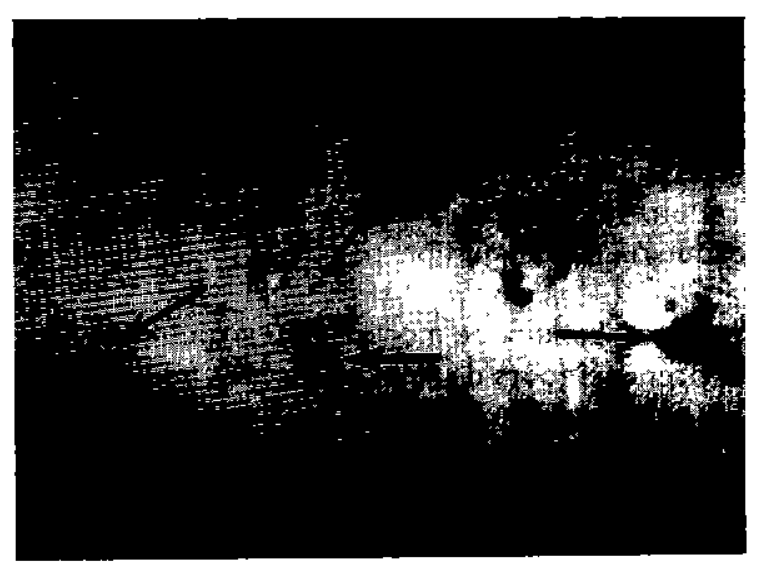

Photo 5. - Ulcérations de la surface dorsale de la langue.

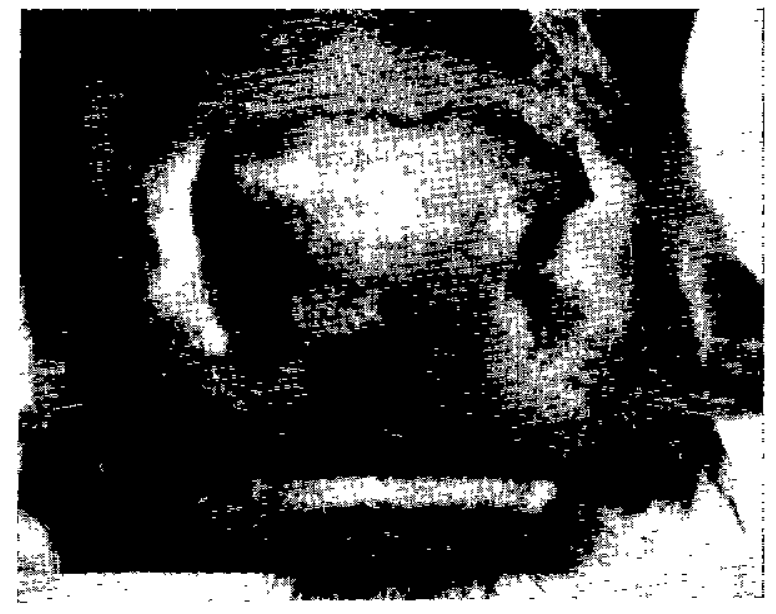

Photo 2. - Ulcérations du mufle.

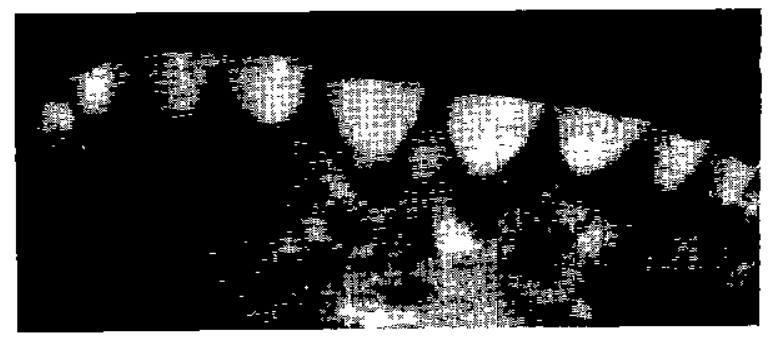

Photo 4. - Ulcérations gingivales.

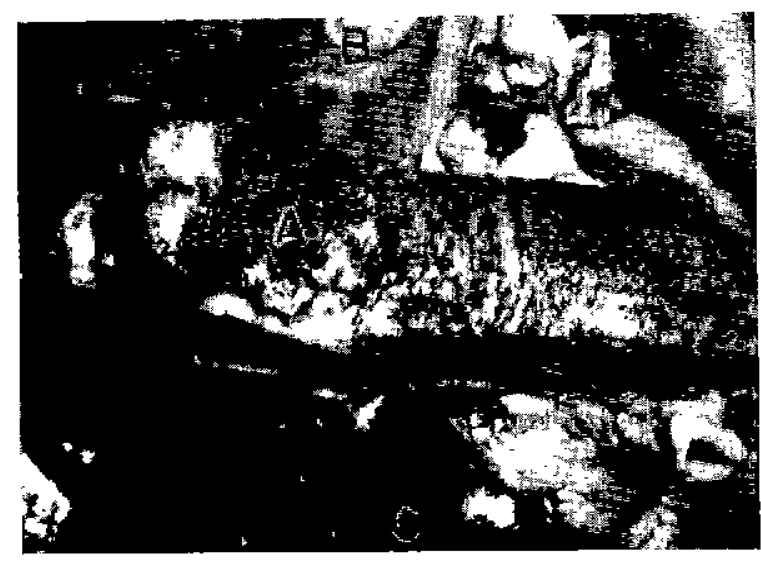

Photo 6. - Ulcérations de la surface dorsale de la langue.

Photo 1 : extraite de Vet, Med., 50 (10) : 431-34.

Photos 2, 3, 4, 5 et 6 : extraites de lowo State Universify Veferinorian (1956) (F. K. RAMSEY. - Pathology of a mucosal disease). 
L'ovoculture est incertaine ef peu d'efforts ont à vrai dire été tentés car le virus se développe bien en cultures cellulaires.

Le pouvorr antigène du virus se manifeste chez les ovins-par la formation d'anticorps neutralisant eł précipitant, ces derniers pouvant être objectivés par la précipitation-diffusion en gélose. La mise en évidence des anticorps déviant le complément n'a pas connu de succès.

Les propriétés immunologı ques du virus VD ont donné lieu à quelques controverses. Les différentes souches isolées par les premiers cuteurs (souche New York, souche Indiana) semblaient être immunologiquement différentes, n'entraînant pas l'immunité l'une envers l'autre. De plus, on séparait ces deux souches d'un même virus de celles d'un autre virus que l'on rendait responsable du syndrome Mucosal Disease, syndrome voisin de l'entérite à virus, à l'intensité des symptômes près.

Il a depuis été démontré que les vırus New-York, Indiana, Californie, Maine, Vırgınıe, lowa, aussi bien que ceux que l'on a pu isoler en Angleterre et en Allemagne, appartenaient au même type immunologique. Jusqu'à plus ample informé, les virus du syndrơme «entérite à virus-mucosal disease » semblent être identiques.

Ils sont nettement séparés du groupe antigénique du virus de la peste bovine. Il n'y a entre eux aucune communauté sérologique, ni aucune immunité croisée. Les seuls rapports qu'ils entretiennent le sont par le biais d'une certaine sımilitude de la maladie clinique qu'ils déterminent sur le bétail. Curieuse et pleıne de promesses virologiques et immunologiques est par contre la parenté séralogique qu'a mise en évidence DARBYSHIRE entre le virus de l'entérite à virus et celuı de la peste porcine. Les lignes de précipitation en gélose sont identiques et inoculés respectivement chez leurs hôtes hétérologues, le virus VD protège le porc envers l'épreuve virulente de virus suipestiquetandıs que ce dernier virus immunıse le veau vis-à-vis du virus VD. On devıne immédiatement à quelles intéressantes applications cette découverte ouvre le champ.

Symptômes. - On distingue trois formes cliniques : une forme aiguë, une forme subaiguè ou clinique ef une forme chronique.

Dans la forme algué, l'apparition des symptômes est brutale. On note de la fièvre assez élevée $\left(40^{\circ} \mathrm{C}\right)$, un catarrhe oculo-nasal, un peu de toux, un état de dépression très caractérisé et de l'anorexie. Les matières fécales sont généralement dures, noirâtres, recouvertes de mucus et de sang.

Ces symptômes persistent une semaine au cours de laquelle on assiste à une baisse puis à une remontée de la fièvre (courbe de température diphasique). Apparaît sur un certain nombre d'anımaux (environ 50 p. 100) une congestion buccale, nasale et génitale très márquée qui laisse la place d'abord à de petites taches blanchâtres, puis à des érosions ulcéreuses qui vont s'étendant. Les ulcères, à bords nets et à fond plał rougeâtre, se rencontrent dans les naseaux, sur le mufle, sur les bourrelets, àl'intérieur des joues, sur le palais, les faces dorsales et ventrales de la langue. L'haleıne est fétide. La sérosıté nasale s'épalssıt, devient visqueuse et en séchant adhère au mufle en y retenant des débris de fourrage. On observe parfois une opacité de la cornée et la présence de pityriasis notamment, dans la région cervicale (symptôme assez fréquemment retrouvé au Soudan).

La diarrhée apparaît à la fin de la première semaine de maladie. Au début les fèces sont liquides ; elles contiennent énormément de mucus et un peu de sang. Les animaux perdent rapidement du poids et se déshydratent très vite. Lorsque la mort doit se produire, la diarrhée ne cesse pas; avant la fin on observe du ténesme. On note parfois de la boiterie due à une congestion podale et interdigitée. L'avortement peut se produire.

La maladie, sous cette forme, dure de deux à six semaines. Le taux de mortalité est variable de 5 à 50 p. 100. La mort survient ordinairement dans les dix premiers jours de la maladie chez les veaux emportés par la phase aiguë (et ceci est tout spécialement vrai lorsqu'existent des lésions muqueuses) ou bien elle est le fait d'une diarrhée de longue durée qui amène les animaux à la cachexie et à l'épuisement.

La forme subarguë semble être très courante chez les veaux de moins de deux mois. Les animaux malades présentent un jetage liquide, une légère fièvre et un peu de diarrhée qui peut persister pendant quelques jours. Les lésions buccales sont rares et l'état général est peu affecté. 
La forme chronique peut être primitive ou faıre suite à la forme aiguë. Le début en est insidieux; les animaux malades s'amaıgrissent et présentent une dıarrhée continuelle ou intermittente. S'il y a des ulcérations, elles traînent en longueur, convergent, s'étendent, s'infectent secondairement au niveau du pied. La congestion coronaire est fréquente; le bourrelet se gonfle, suinte, en même temps que l'espace interdigité.

Le marasme entretenu par la diarrhée persistante où se rencontrent sang et fausses membranes, fait que les malades se cachectisent de plus en plus et succombent en cinq à six semaines.

Pronostic. - La forme aigue, lorsqu'elle ne tue pas d'emblée les veaux, ne se traduit chez un bon nombre de sujets que par des lésions limitées qui peuvent guérir rapidement. Chaque animal est affecté durant huit à dix jours et l'effectif est libéré de la contagion en quatre à six semaines. Plus désastreuse en fin de compte est la forme chronique trainant pendant de longs mars et ne laissant qu'une fasble proportion de rescapés récupérables.

Lésions. - Le cadavre est émacié, sovillé de diarrhée. Les yeux sont enfoncés dans les orbites, le mufle recouvert de croûtes.

Lésions macroscopiques. Deux types de lésions sont à signaler : les lésions des muqueuses eł celles des ganglions lymphatiques.

Sur toutes les muqueuses du tractus digestif existent de la congestion, des hémorragies, des érosions et des ulcérations. Ces dernières, allant du « coup d'ongle » à des larges placards, sont formées par l'abrasion de la couche épithéliale superficielle, laissant un chorion rougeâtre entouré d'une petite auréole inflammatoire. Ces ulcérations siègent dans toute la cavité buccale (avec une prédilection pour la lèvre inférieure ef le palais), sur toufe la langue, qui peut parfois prendre un aspect complètement desquamé. Dans l'œsophage, elles sont plus discrètes, mais dans la caillette on trouve de larges placards ulcérés surtout dans le fundus et près du pylore.

L'intestin grêle est peu touché et ne présente guère qu'une entérite mucolde. Le gros intestin par contre est sévèrement atteint. On y trouve de larges taches hémorragiques sur la grande courbure à l'opposé de l'insertion mésentérique et tout autour de la valvule iléo-cœecale. Les plaques de Payer tranchent par leur couleur rouge sombre. Les plis du rectum sont le siège de suffusions sanguines plus ou moins accusées.

Les ganghions lymphatiques sont turgescents ef congestionnés.

L'appareil respiratoire est rorement touché : on n'observe qu'une congestion avec ulcères des naseaux, une rhintte catarrhale et un peu de congestion trachéale.

Lésions microscopiques. Elles sont du type dégénératif. Lors de la formation de l'ulcère, il y a d'abord une balionisation du protoplasme auquel fait suite la nécrose cellulaire, puis la desquamation. L'infiltration cellulaire ou leucocytaire n'est pas apparente. On ne note jamais la présence des cellules multinucléées comme dans la peste.

Les altérations des ganglions lymphatıques sont constituées par une disparition totale des cellules mononucléées du cortex. II ne reste que la trame conjonctive.

Le tableau hématologique est domıné par la leucopénie. Elle apparaît au début de la maladie. Elle est, avec la fièvre diphasique, l'une des plus sûres constantes symptomatologiques de la maladie expérimentale.

Diagnostic. - Les signes de suspicion sont la fièvre, la déshydratation, la congestion ef les ulcérations buccales, la diarrhée sanguinolente. On mesure d'emblée combien de points sont communs avec d'autres viroses.

Le diagnostic sera donc mené en trois éłapes : clınique, nécropsique, expérimentale.

1. Diagnostic clinique. Le faisceau de signes critères évoqués plus haut devra être étayé par l'enquête épizootiologique. Celle-ci est de la plus haute impartance ef permettra bien souvent de différencier l'entérite d̀ virus de la peste bovine selon que l'affection évolve sur un troupeau vacciné ou non contre la peste. La qualité des vaccins antipestiques actuels et l'intensıté des campagnes de vaccination doivent à eux seuls apporter une quasi-certitude. 
Classiquement, la peste se montre plus rapide dans sa contagion et plus sévère dans sa clinique. A vrai dire, cette affirmation n'a rien de vrai de nos jours où les pestes torpides et bénignes sont le lof commun lorsqu'elles évoluent sur des bouvilions en état de semi-immunité. Toutefois un signe clinique est de la plus grande importance lorsqu'existent des ulcérations : il n'y a jamais d'ulcérations sur la face dorsale de la langue dans la peste bovine olors qu'elles existent pratiquement toujours dans l'entérite à virus. Rien d'autre dans les lésions ne peut permettre de distinguer les deux maladies.

Les aphtes, même rompus, de la fievre aphteuse, ne seront pas confondus avec les ulcères de l'entérite à virus. L'atteinte podale (rarement mammaire sur le bétail zébu) aidera au dıagnostic. La diarrhée enfin n'est pas un symptôme de la fièvre aphteuse.

L'absence de diarrhée, les symptômes oculaires (opacification cornéenne), la faible morbidıté et la mortalité élevée du coryza gangréneux permettent de le différencier de l'entérite à virus.

Les différentes stomatites (stomatite papuleuse, stomatite vésiculeuse, nécrobacillose ou diphtérle des veaux) évoluent toutes sans diarrhée et ont des caractères particuliers.

La blue tongue n'a pas encore été rapportée en Afrique centrale, mass elle pourrait s'y introdure. Chez les bovins, elle risque d'en imposer dans ses diverses localisations au stade ulcéreux (inflammation localisée de la langue avec nécrose des muqueuses buccale et nasale) mais la diarrhée manque.

La maladie des radiations atomiques sera essentiellement hémorragique, sans diarrhée.

La maladie de johne a une épizootiologie particulière et n'a pas encore été signalée en Afrıque centrale.

La coccidiose est éliminée par l'absence de congestion et d'érosions buccales. Il ne faut pas oublier que la présence de coccidies n'élimine pas une entérite à virus (non plus que la peste).

Les salmonelloses peuvent prêter à confusion, mas les lésıons sont limitées à l'intestin. L'ısolement du germe permet le diagnostic.

2. Diognostic nécropsique. II est basé sur la constatation des lésions décrites, Il est habituellement si frappant qu'il faut prendre bien garde de ne pas porter d'emblée le diagnostic de peste. Seul l'examen de la langue sur toutes ses faces permettra de lever le doute.

3. Diagnosfic expérimental. L'inoculation à un autre bovin est une épreuve sûre. A partir d'inoculats variés : matériel fécal, sang, suspension de tissu splénique, on reproduit une maladie, constante dans ses deux expressions : hyperthermie et leucopénie, plus rare avec le cortège ulcératif et diarrhéique.

Un test de précipitation en gélose a été récemment décrit. Il utilise comme antigène les tissus touchés par le virus : muqueuse buccale, muqueuse jugale (excellente), muqueuse pharyngée, muqueuse intestinale qui sont broyées après prélèvement, et le broyat est placé dans l'une des cupules de boîtes de Pétri remplies de gélose. L'antisérum provient d'un animal malade, mais on peut mettre à profit la communauté antigénique avec le virus suipestique et utilıser un hyperimmun sérum contre la peste porcine. La réaction positive se traduit, après 24 heures d'incubation à température ordinaire, par une ligne de précipitation entre les deux réservoirs.

Etiologie. - 1. Matières virulentes. Ce sont le jetage, les fèces, et expérimentalement le sang et la rate. Les matières fécales restent longtemps virulentes ( 5 mois).

2. Résistance du virus. Le virus n'est pas très résistant et est inactivé rapidement par la chaleur. Au froid, il se conserve aisément à $-40^{\circ} \mathrm{C}$ mais il est rapidement détruit à $-20^{\circ} \mathrm{C}$.

3. Réceptivité. L'espèce joue un rôle primordial : seuls les bovins et le daim sont, dans les conditions naturelles, sensibles au virus. La race et le sexe ne semblent pas avoir d'influence. L'âge conditionne plus sûrement la réceptivité : les très jeunes et les sujets âgés sont résistants ; les plus sensibles sont les bovins âgés de 8 à 24 mois ; ils présentent les symptômes les plus marqués.

4. Mode de contagron. Elle est assurée par le contact direct, moins sûrement par le contact indirect. On a pu remarquer que le fait d'intercaler dans une étable des animaux âgés entre les veaux à 
l'attache faisait cesser l'extension de la maladie chez ces derniers. Dans les conditions naturelles la transmission du contage se fait au pâturage.

Pathogénie. - Aucune notion précise n'est connue, en dehors du tropisme du virus pour les. lymphocytes.

Prophylaxie. - Les mesures de prophylaxie sanitaıre sont celles ordinairement prises dans toute maladie contagieuse.

La prophylaxie médıcale fait appel à la vaccination par virus vivant. Elle est parfaitement justıfiée en certains pays comme ceux de l'est des Etats-Unis où les pertes économiques que cause l'entérite à virus sont importantes. II existe deux vaccins :

- Vaccin lapınisé. II est préparé à partir de rates de lapins infectés par le virus VD souche New York 1, atténué par un minimum de 75 passages en série chez le lapin.

La vaccination se fait au sevrage. II n'y a qu'une réaction thermique insignifiante et pas de leucopénie. L'immunité est d'excellente qualité mais on ne sait encore rıen sur sa durée.

- Vaccin de culture cellulaire. Il est préparé sur cellules de rein de veau avec la souche Oregon C $24 \mathrm{~V}$ atténuée par 32 passages en cultures. Le vaccin s'emploie comme le précédent et ne donne aucune réaction vaccinale. L'immunité est solıde mais on ne connaît pas sa durée.

\section{B. - AFFECTIONS ATtEIGNANT LA MUQUEUSE BUCCALE}

Nous avons déjà évoqué certaines stomatites lors du diagnostic clinique de l'entérite à virus. Nous en préciserons ici quelques modalités cliniques qui aideront à leur reconnaissance.

\section{I. - FIÈVRE APHTEUSE}

Diagnostic épizootiologique. La contagiosité de la fièvre aphteuse est plus subtıle que celle de la peste. En quelques semaines, elle s'étend à une région naturelle; en quelques mois, elle touche tout un territoire. C'est ainsi qu'en 1960, le Tchad fut entièrement contaminé du nord au sud en l'espace de deux mois par un virus du type $A^{*}$.

En Afrique accidentale et centrale, elle frappe par vagues épizootiques espacées de plusieurs années, dont la caractéristique est de toucher pratiquement fous les bovins quel que soit leur âge.

Ces deux caractères : haute contagiosité et réceptivité indépendante de l'âge, la distinguent déjà nettement de la peste bovine.

Diagnostic clinique. La prostration qui a fait donner à la peste classique le nom de «typhus bovin» n'existe pas sur le bétail zébu atteint de fièvre aphteuse.

La trilogie symptomatologique des lésions buccales, podales et mammaires souffre également quelqu'exception : si les lésions buccales et surtout podales sont constantes, les lésions mammares sont becucoup plus rares. Bien souvent l'attention de l'éleveur n'est attırée que par la douleur podale des animaux, qui par ailleurs ont conservé leur appétif. Chez les veaux la douleur buccale peut empêcher la tétée et entraîner la mort par inanıtion. La présence d'aphtes dans l'espace interdigité permet d'emblée d'éliminer la peste bovine du diagnostic.

Les caractères de l'éruption aphteuse sont par ailleurs très particuliers : en dehors de leurs localisations labiales, gıngivales et palatines, les aphtes apparaissent volontiers sur la face dorsale de la langue, ainsi qu'à l'extrémité libre de cet organe; nous savons que les ulcères pestiques ne s'y rencontrent que sur la face ventrale.

L'aphte non rupturé est caractérıstique mais difficile à saısir dans son évolutıon, car fugace est sa présence ; il faut examiner un grand nombre d'animaux pour avoir la possibilité de l'observer. Il se différencie aisément d'une érosion pestique où domıne l'enduit pultacé.

* En trois mois, une vague épizootıque à virus SAT I a déferié d'est en ouest sur le pays durant l'année 1963. 
PLANCHE 2.

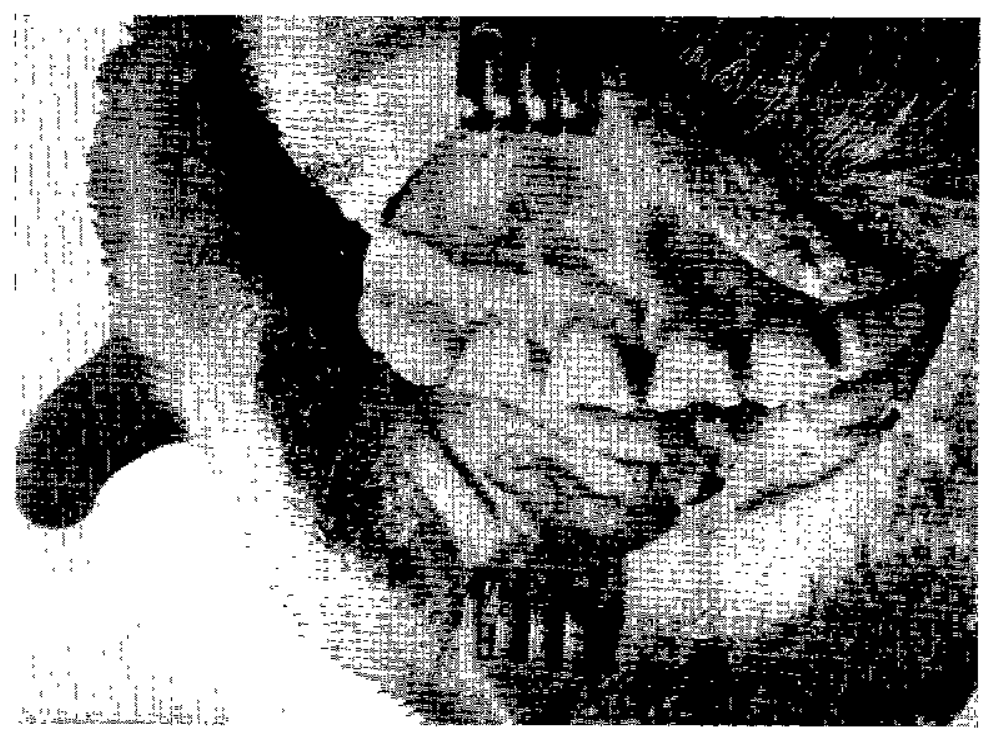

Photo 7. - Fièvre aphteuse - Lésions gingivales.

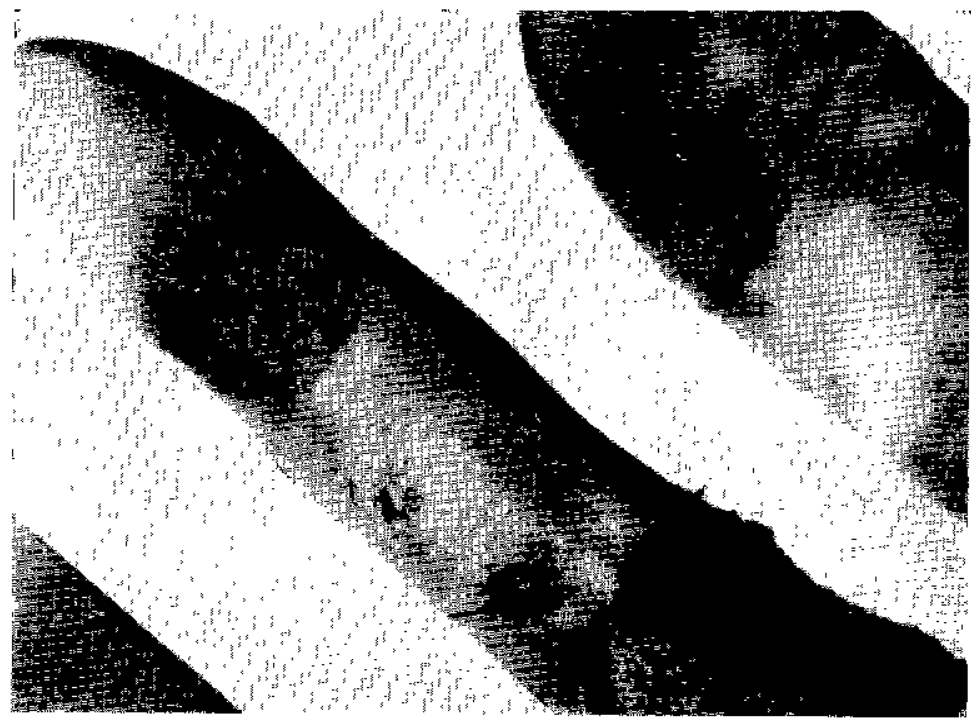

Photo 8. - Fièvre aphteuse - Lésions linguales. 
La présence d'aphtes rupturés ne doit pas indurre le clinicien en erreur : les bords en sont exfoliés; il reste toujours quelques lambeaux de l'éplthélium de l'aphte. Différent est l'uicère pestique, à bords francs, à fond rougeâtre que recouvre un magma caséeux.

La diarrhée enfin n'est pas commune dans la fièvre aphteuse alors qu'elle est un symptôme cardinal dans la peste.

Diagnosłıc nécropsique. Il esł particulıèrement aisé, les lésions de la fièvre aphteuse étant limitées à la cavité buccale.

\section{2. - STOMATITE VÉSICULEUSE}

La stomatite vésiculeuse, virose commune au cheval, aux bovins, au porc, et à l'homme, ne semble jamais avoir été signalée en Afrique en tant qu'entité morbide définie.

Sa symptomatologie est singulièrement semblable à celle de la fièvre aphteuse, hormis la bénignité de son évolution. Sur le bétail zébu, on peut penser qu'on ne saurait les différencier cliniquement.

Les éléments du diagnostic différentiel de la peste bovine donnés pour la fièvre aphteuse s'appliquent ici. La concomitance d'une éruption vésiculaire épithéliale sur les chevaux pourrait la faire suspecter ; le diagnostic exacł appelle le recours au laboratoire.

\section{3. - BLUE TONGUe}

Dans les régions où sévit l'épizootie, cette virose du mouton évolue chez le bœuf sans donner la plupart du temps de symptômes cliniques. La maladie bovine a néanmoıns été décrıte en Afrıque du Sud, au Portugal, en Espagne, et aux Etats-Unıs. Connu depuis 1923 en Afrique occidentale, l'isolement récent du virus de la blue-tongue en Nigeria du Nord (1958) peut faire craindre une flambée de la maladie chez les bovins d'Afrique centrale, comme ce fut le cas en 1935 en Afrique du Sud et en 1957 en Espagne. Il importe donc de savoir reconnaître la maladie bovine.

Diagnostıc épizootiologique. La maladie bovine ne se verra que concomitante ou subséquente à la maladie ovine. Ce sera une maladie de début de la sasson des pluies, sévissant de préférence dans les régıons marécageuses où l'eau stagnante se prête à la prolifération des Aedes et Culicoides, vecteurs du virus.

Diagnostic clinique. Les rares bovins présentant des symptômes cliniques de blue-tongue montrent une inflammation des muqueuses buccales et nasales survie de nécrose. II n'y a pas de localisation en Ulcères comme dans la peste.

En même temps qu'apparaissent ces lésions nasales et buccales, on note un œdème de la mamelle qui se congestionne ef peut manifester de la nécrose superficielle. La sécrétion lactée se tarit.

Le processus congestif atteint parfois le pied, avec rubescence du podophylle et de la couronne, puis nécrose, décollement et chute des onglons.

Ces atteintes mammaires et podales sont tatalement inconnues dans la peste. Enfin, la bluetongue bovine n'est jomais martelle.

Diagnostic expérimental. II est fondé sur la mıse en évidence du virus ou des anticorps sériques chez les convalescents.

L'Isolement du virus se falt en inoculant du sang citraté dilué au $1 / 10$, soit à un mouton d'un an environ chez qui devra évoluer la maladie typıque de la «langue bleve», soit à des cultures cellulaires de rein d'agneau, à l'œuf de poule embryonné, aux souriceaux ou aux hamsters nouveau-nés.

La sérologie recherchera dans deux prélèvements de sérum sur le même animal (l'un à l'acmé de la maladie, l'autre trois semaines plus tard) une montée d'anticorps neutralisant le virus en cultures cellulaıres ou sur œuf embryonné, ou d'anticorps déviant le complément.

En tout état de cause, le diagnostic de blue-tongue bovine ne peut être qu'un diagnostic d'exception. 
PLANCHE 3.

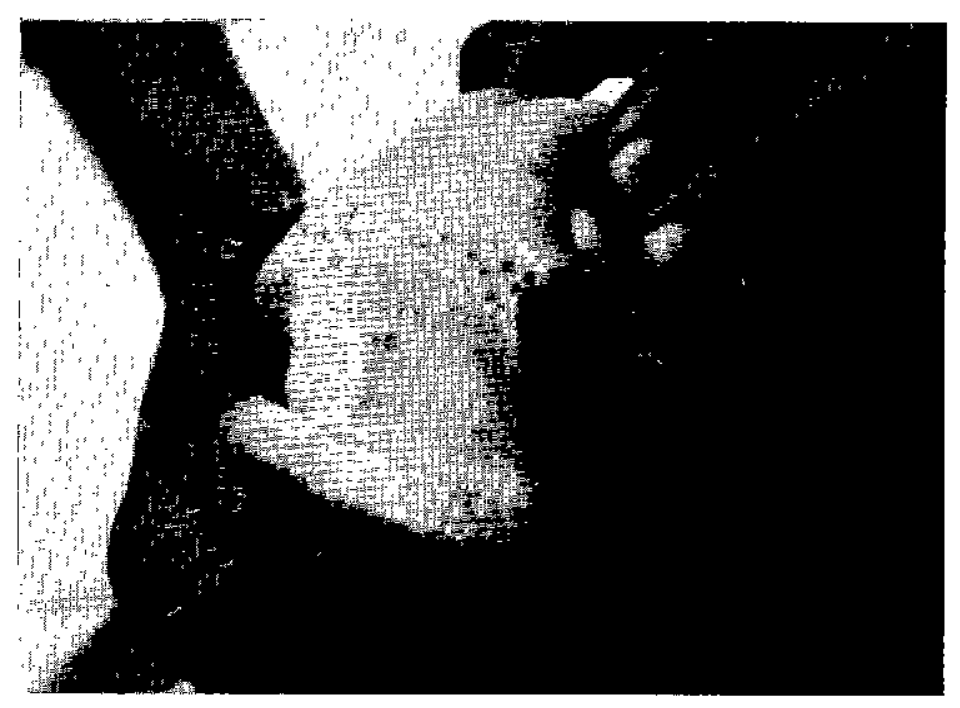

Photo 9. - Stomatıte papuleuse - Lésions gingivales*.

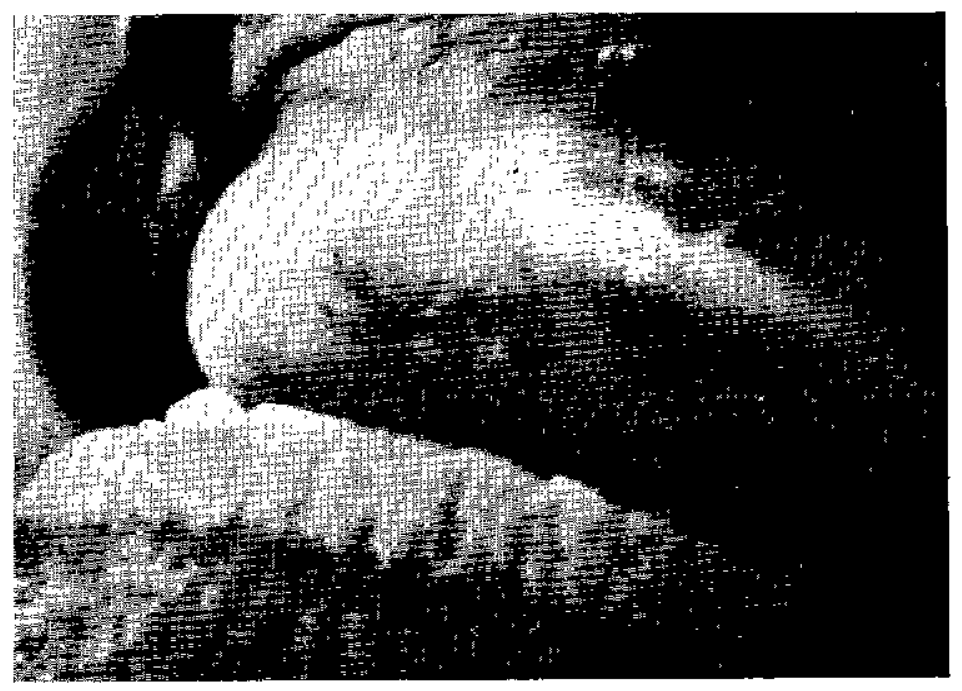

Photo 10. - Stomatite papuleuse - Lésions gingivo-palatınes*.

* Clichés Mackowiack. 


\section{4. - stomatite papuleuse}

La stomatite papuleuse est une maladie infectieuse, contagleuse, récurrente, spéciale aux bovıns. Elle est due à un virus spécifique, classé dans le groupe des poxvirus à côté de celui de l'ecthyma contagieux.

Elle est extrêmement fréquente en Afrique.

Epizootiologie. La maladie atteint les bovins sans distinction d'âge, des jeunes à la mamelle aux adultes. Une première attaque ne confère pas l'immunıté et il n'est pas rare de voir plusieurs vagues successives d'éruption. Dans un troupeau sa marche est extrêmement rapide, et son évolution bénigne. Elle peut coexister avec la peste bovine.

Symptômes. II n'y a aucune élévation thermique, ni aucun abattement. Seuls les animaux les plus atteints présentent un peu de dysphagie pendant quelques jours à cause de la douleur buccale.

On note à l'inspection du mufle des croûtes brunâtres, circulaıres, de quelques millimètres à un centimètre de diamètre. Ces croûtes entourées d'un anneau congestif ou jaunâtre se retrouvent sur le bord des naseaux, aux commissures labiales et sur la lèvre inférieure. Lorsqu'on les détache, elles laissent une surface congestionnée et saignante, à bords francs ef en surplomb (planche 2).

Des lésions de type identique se révèlent à l'inspection de la bouche, sur la gencive inférieure, où elles ont un lieu de prédilection à la base de la troisième incisive, sur la gencive supérieure, sur les faces internes des lèvres, plus rarement sur les deux faces de la langue. Sur le palais, elles prennent volontiers l'aspect de larges plaques transversales. Les croûtes tombent rapidement, laissant une plaque ulcérée à bord franc, parfois recouverte d'un enduit pultacé blanchâtre non fétide. Ces ulcères, sans tendance à l'extension, prennent parfois un aspect cratériforme et cicatrisent en quelques jours par régénération de l'épithélium.

li n'y a ni rhinite, ni conjonctivite, nı diarrhée.

La présence de croûtes, l'évolution bénigne distinguent nettement la stomatite papuleuse de la peste. Toutefois, la présence d'ulcères buccaux dait faire soupçonner cette dernière maladie ; l'examen d'autres animaux du troupeau, l'évolution ultérieure renseigneront.

\section{5. - diphtérie bovine ou nécrobacillose}

Le bacille de la nécrose, Spherophorus necrophorus, ou bacille de Schmorl, provoque diverses infections suppuratives des bovidés et des ovidés et est également reconnu comme l'agent étiologique principal de la diphtérie du veau.

Cette maladie du jeune veau de huit jours à trois mois ne prend pas des allures d'épizootie. Elle est rarement rapportée en Afrique, où son agent étiologique cause cependant des infections spécifiques (inflammation du canal biflexe du mouton...)

Diagnostic épizootiologique. Cas isolés ou en tout petits foyers uniquement sur les veaux. En même temps peuvent exister des abcès interdigités sur les bêtes adultes.

Diagnostic clinique. Anorexie due à la douleur buccale. La muqueuse des joues, du palais et de la langue se couvre de taches grisâtres qui se fransforment, les jours suivants, en dépôts rugueux, gaufrés, jaunatres, en surplomb sur la région avoisinante. Les fausses membranes tombent, laissant une muqueuse ulcérée en larges plaques d'aspect livide. La salive s'écoule à l'extérieur, entraînant des sphacèles nécrosés. Le processus peut atteındre les cavités nasales et touche très souvent le larynx, entraînant un tirage respiratoire et des accès de toux et de suffocatıon.

Le tableau clinique, la présence de fausses membranes, séparent nettement cette maladie de la peste bovine.

\section{6. - STOMATITES DIVERSES}

Nous citerons pour mémoire:

- la stomatite traumatique, que l'on rencontre chez les veaux au sevrage broutant le fourrage dur de la saison sèche. 
- les stomatites dues à divers produits chimiques dont la rareté dans la vie pastorale afrıcaine réduit singulièrement cette catégorie d'affection.

- la stomatite pseudo-aphteuse épidémique de Moliaret et Salomon, virose bénigne évoluant avec l'apparition de lésions éruptives buccales de courte durée.

- éventualité rare, les brôlures par ypérite pourraient en imposer pour des ulcères pestiques. Le contexte épizootiologique apporte des renseignements ef les brôlures dues à l'ypérite * sont confinées aux premières parties du tractus digestif.

— la maladie de la bombe atomique où l'exposition plus occulte à des radiations ionisantes $\alpha, \beta$ et $\gamma$ produit chez les bovins, en dehors des brôlures externes ef d'alopécies localisées, des érosions ef des ulcères de taut le tractus digestif qu'accompagnent des hémorragies rénales et pelviennes. La lymphopénie est intense. Ce tableau lésionnel se retrouverait avec plus d'intensité encore chez les porcs et surtout les chèvres, espèces qui ne font habituellement en Afrique qu'une peste bovine asymptomatique.

\section{C. - AFFECTIONS ATTEIGNANT LA MUQUEUSE CONJONCTIVALE}

L'atteinte conjonctivale avec larmoiement abondant est pratiquement constante dans la peste bovine à son début.

Elle se voit dans de nombreuses maladies infectieuses bovınes, comme l'entérite à virus, la rhinotrachéite infectieuse, le coryza gangréneux, et les rickettsioses bovines, comme la maladie d'Ondiri ou purpura hémorragıque infectieux.

Il faut signaler pour mémoire l'action traumatisante du nématode Thelazia rhodesiense qui peut parasiter les culs-de-sacs conjonctivaux.

On différenciera les conjonctivites et kératites banales, contagieuses ou non, d'étiologie bactétienne ou rickettsienne.

\section{D. - AFFECTIONS ATTEIGNANT LES MUQUEUSES RESPIRATOIRES}

En dehors de quelques formes atypiques rapportées en Egypte, la peste bovine ne touche pas les poumons. Cependant, il existe dans le cortège symptomatologique de la peste, une importante part jouée par le jetage nasal qui, se desséchant et obstruant les naseaux, contribue à donner au bovin malade son aspect de «typhique».

A l'autopsie, on trouve les cornets nasaux et le septum recouverts d'un muco-pus adhérent qui cache une muqueuse pétéchiale. Les lésions de la muqueuse buccale s'étendent au larynx et la frachée présente, signe invariable, des bandes longitudinales hémorragiques.

Il y a plusieurs maladies qui présentent cet aspect clinique et ces lésions, avec en tout premıer lieu : la rhinotrachéite bovine infectieuse ***. Le coryza gangréneux peut en imposer. La nécrobacıllose s'en distinguera plus aisément.

\section{1. - LA RHINO-TRACHÉITE BOVINE INFECTIEUSE}

Maladie infectieuse, virulente, contagieuse et inoculable due à un virus isolé par MADIN, YORK et Mc KERCHER en 1956.

La maladie est caractérisée cliniquement par de la fièvre, l'hyperémie des muqueuses des premières voies respiratoires et l'écoulement d'un exsudat des cavités nasales; anatomiquement, par des lésions de rhinıte, de trachéite, de laryngite.

* Gaz de combat vésicant utilisé en Europe pendant la guerre 1914-18.

** en abréviation RB! 


\section{PLANCHE 4.}

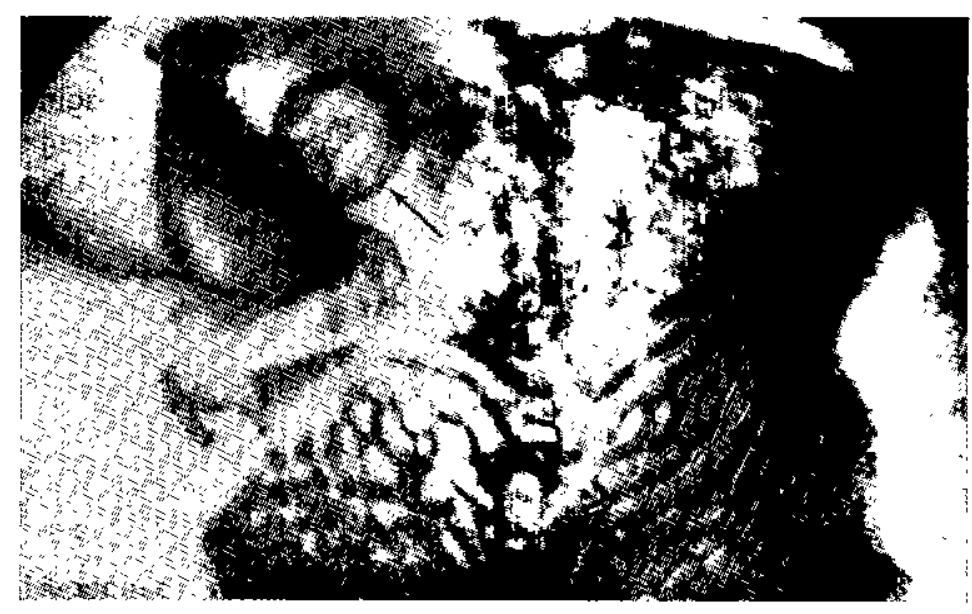

Photo 11. - Stomatite papuleuse - Lésıons du mufle.

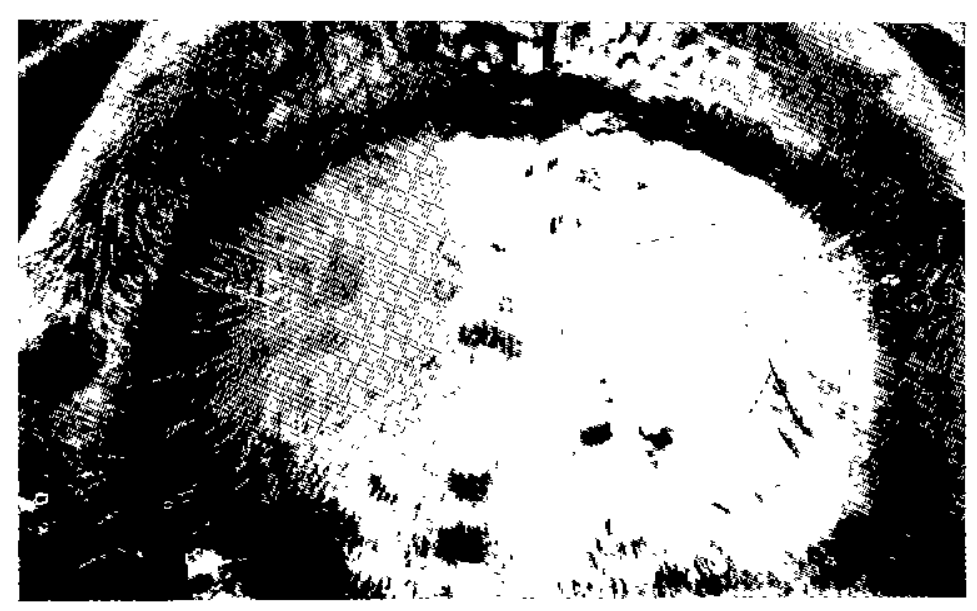

Photo 12. - Stomatite papuleuse - Lésıons labiales.

Photos 11 ef 12 extraites de Am. J, vet. Res, 1961, 22 (88) : 473-81. 
Historique et aire géographique. - C'est en 1950 qu'au Colorado a été cliniquement décrite une nouvelle entité morbide se traduısant par uneviolente inflammatıon des voies aériennes supérieures, accompagnée d'un coryza important. La maladie fut reconnue dans tous les Etats de l'Ouest américain sur le bétall destiné à l'embouche (1953), puis dans ceux de l'Est sur le bétail laitier (1957) ; on doit considérer que tout le continent nord-américaın, Canada y compris, est infecté. Son nom lui a été donné en 1957, année où elle fut détachée du groupe «Mucosal disease complex» où elle étaitjusqu'alors incluse.

GILLEPSIE montra en 1958 l'identité du virus de la RBI avec celul de la vaginite granuleuse ; un seul et même virus est l'agent étiologique de deux maladies bovines cliniquement très différentes.

Le virus RBi a été isolé et étudié en Allemagne en 1959, la même année en Nouvelle-Zélande, et en Angleterre tout récemment (1962). Des sondages sérologiques effectués en France montrent que le bétail français possède des anticorps neutralisants et se trouve donc infecté.

La maladie existe en Afrique centrale ; le virus n'a pas encore été isolé mais un syndrome identique à la RBI a été observé tout autour du Lac Tchad *.

Espèces affectées. - Dans les conditions naturelles, la RBI ne touche que les bovins.

Expérımentalement un syndrome fébrile est reproduit chez le chevreau. Le cheval et le mouton sont totalement réfractaıres à l'inoculation, mais ils fabriquent des antıcorps neutralisant à un taux significatif. Le lapin développe une lésion localisée au point d'inoculation intradermique.

Epizootiologie. - La rhinotrachéite est une maladie grave du bétail d'embouche. Aux Etats-Unis, elle apparaît par véritables vagues épizootiques sur le bétail des «feed-lots » : ce sant des bovins de quatre à cinq ans achetés dans des ranchs, parqués par plusieurs milliers, et engraissés avant d'être envoyés à la boucherie. Dans ces parcs, de l'introduction de bovins malades résulte une contagion qui s'étend généralement à l'ensemble des anımaux. La maladie existe aussi, plus larvée, sur le bétail de ranch. Le bétail laitier fait des formes plus frustres. Chez eux, la maladie se déclare souvent après l'intraduction dans l'étable d'un bovin nouvellement acheté.

En Afrique centrale, on la voit évoluer dons les troupeaux de veaux que l'on constitue après le sevrage des animaux ; son évalution y est bénigne.

L'immunité suit une premıère atteinte de la maiadie. La RBI n'esł pas une maladie de saison froide comme on pourrait s'y attendre. Au contraire, sa plus grande fréquence se situe à la fin de l'été et au début de l'cutomne.

La morbidité varie de 10 à 20 p. 100 du troupeau, la mortalité de 3 à 10 p. 100 des malades.

Virologie. - L'agent étiologique de la RBI est un ultra-virus. Sa forme est sphérique et sa taille oscille autour de $150 \mathrm{~m} \mu$. Il est formé d'un matériel interne sphérique (le nucléoïde viral) de $45 \mathrm{~m} \mu$ de diamètre ; une double membrane entoure le nucléorde.

Ce nucléoide est formé d'un seul acide nucléique qui est un acide désoxyribonucléique.

Ces caractères morphologiques, étayés de la stabilité chimique et des lésions cellulaıres déterminées en cultures, font ranger le virus dans le groupe des Herpés ou Nitavirus (qui comprend le virus de l'herpés, de la varicelle, le virus B du singe, le virus de l'avortement des juments et le virus $d^{\prime}$ Aujeszky).

Le virus est relativement thermostable : il reste entièrement viable après congélation à - 600 et son titre ne baisse que de peu après un mois au réfrigérateur. Par contre, il esł détruit en 50 jours à

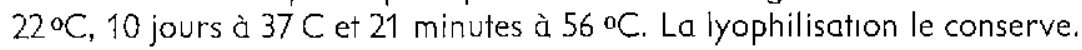

Le virus est inactivé en 1 minute par l'éther, l'acétone ef l'alcool éthylıque. Il est inactivé en 24 heures par la solution de formol au 1/500 et en 96 heures par celle au 1/5000. II reste stable entre les pH 6 et 8 , mais il est inactivé au-dessous de $\mathrm{pH} 6$. II n'hémagglutine les hématies d'aucune espèce.

La culture du virus se réalise alsément in vitro. Un grạnd nombre de tissus sont sensibles, ne reflètant pas ainsi la stricte spécificité de la maladie bovine : cellules humaines normales ou cancéreuses,

* Tout récemment (juillet 1963), le vırus a été isolé au Tchad sur des bovins, présentant à la fois les symplômes de rhınotrachélte et de vaginite granuleuse. 


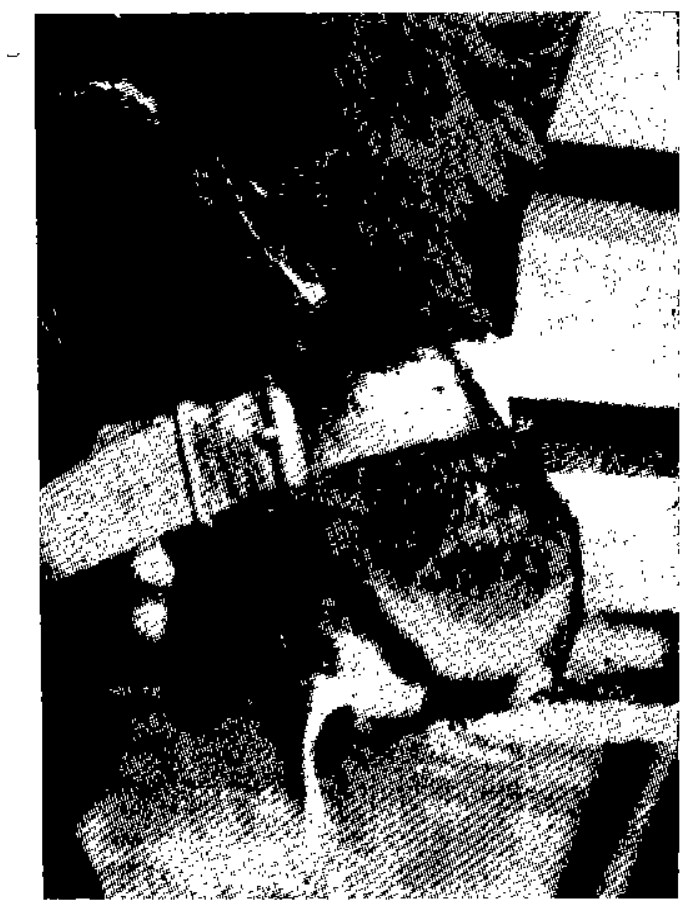

Photo 13. - Rhinotrachéite bovine.

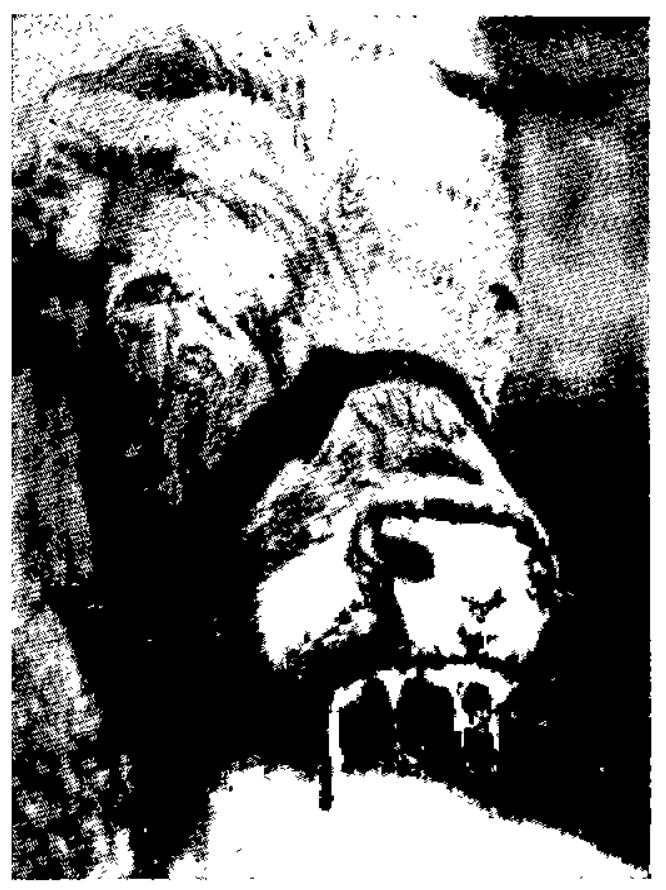

Photo 15. - Coryza gangréneux.

Photos 13 et 14 : extraites de Disch. tierúrztl. Wochr.

Photo 15 : extraite de Vet. Med. 1959, 54 (10) : 509-12.

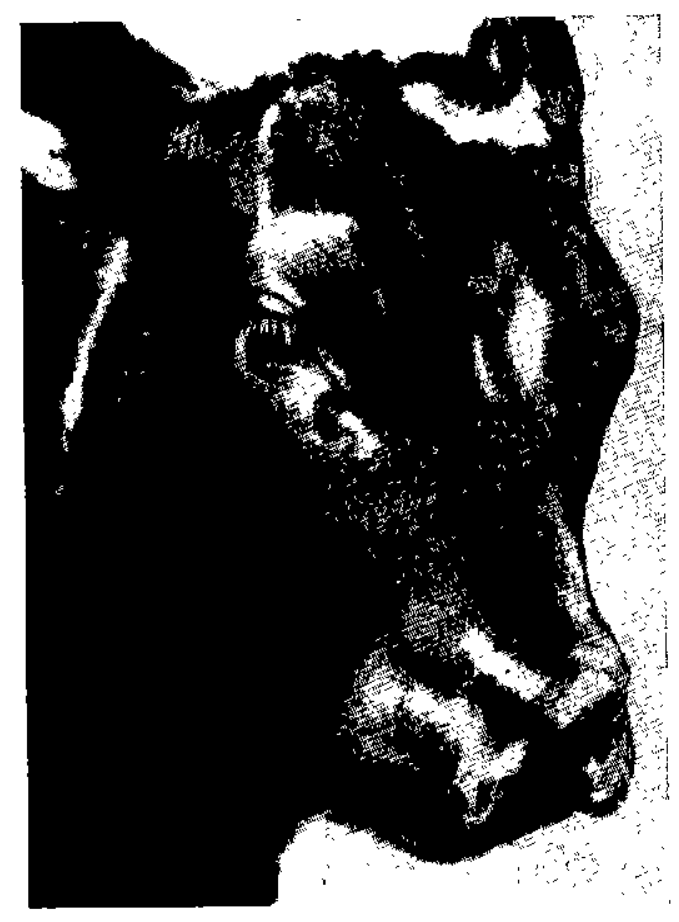

Photo 14. - Rhinotrachéite bovine. 
cellules de rein de porc, de veau, de chèvre, de mouton, de cheval, de chien, testicule de lapin... Il ne se multiplie pas en fibroblastes de poulet (pas plus que dans l'œuf embryonné). Dans łous ces systèmes cellulaires, le virus détermine un effet cytopathique particulier des cellules infectées : des inclusions rondes intranucléaires (inclusions intranucléaires du type A de Cowdry) apparaissent. Ensuite les cellules s'arrondissent, deviennent granuleuses ; la culture se lyse en 72-96 heures.

Le pouvorr pathogène du virus n'est patent que pour le bouf. La maladie est reproduite par badigeonnage de la muqueuse nasale, inoculations intratrachéales ou aérosols de produits virulents ou du virus de culture. La maladie clinique est reproduite avec ses symptômes. L'inoculation intramusculaire ne reproduit pas la maladie mais entraîne l'immunité. II n'y a pas d'animal expérimental,' hors le chevreau de peu d'utilité.

Les propriétés antigéniques du virus RBI n'ont fait l'objet que de quelques études. Un seul type antigénıque a été isolé jusqu'à présent de par le monde. Le virus de la RBI a une communauté sérologique avec celui de l'avortement des juments (virus de Dimack efj Edwards ou equine rhinopneumonitis virus). Ils donnent naissance d̀ des anticorps déviant le complément et précipitant pour l'un ou l'autre virus, mais les anticorps neutralisants sont spécifiques. Les deux virus ont donc des relations antigéniques mais non immunologiques.

Les propriétés immunigènes sont objectivées par l'immunité solide et durable (au moins 2 ans) qui suit une première atteinte de la maladie. Cette ımmunité se reflète dans l'existence d'anticorps sérıques neutralisant le virus, mais dont le titre chez un même animal est sujet à de grandes fluctuations sans que pour cela baisse l'ımmunité à l'inoculation d'épreuve.

Symptômes. - Après une période d'incubation variable de 10 jours d̀ plusieurs mass après l'introduction du contage dans un troupeau par un bovin étranger, la maladie se présente sous deux aspects : grave ou bénin.

- Allure grave. Le début de la maladie est brufal et est marqué par une forte fièvre $\left(41-42^{\circ} \mathrm{C}\right.$ ). Pendant un à deux jours, l'habitus n'est pas changé. Puis apparaissent une congestion et un catarrhe nasal, une sialorrhée intense et une accélération de la respiration. On peut en même temps observer une conjonctivite.

La dyspnée va s'accentuant tandis que s'épaissit la décharge nasale. La toux peut exister mais n'est pas constante. La muqueuse visible des cavités nasales est hyperémiée, et dans les 48 heures suivantes peut se marquer de zones de nécrose qui se transformeront en ulcères (planche 3).

Ces manifestations locales s'accompagnent de symptômes généraux : suppression de l'appétit, déshydratation, cessation totole de la sécrétion lactée.

La mort peut se produire brusquement dès ce stade par complications pulmonaires, mais dans la grande majorité des cas les symptômes commencent à s'amender. Chez d'autres, la sérosité nasale devient mucopurulente, puis purulente et la maladie suit un cours lent qui les contduit au marasme et ¿̀ la mort.

Chez les vaches laitières, il y a parfois un emphysème sous-cutané rétroscapulaire et abdominal. L'avortement peut survenır chez les femelles. La durée totale de la maladie est de dix à quinze jours.

- Allure bénigne (maladie africaine). Elle se traduit par une température élevée pendant quelques heures, un catarrhe nasal pendant quelques jours, puis tout rentre dans l'ordre. C'est ce que l'on obtient dans la maladie expérımentale.

L'allure générále de la RBI non compliquée est celle d'une inflammation catarrhale des premières voies respiratoires. Il n'y a jamais, ni érosions buccales nı diarrhée.

Lésions. - 1. Macroscopiques. Elles siègent dans les voies respiratoires supérieures.

On relève une congestion intense de la muqueuse nasale avec parfois des pétéchies. L'exsudat est clair dans les cas bénins, mais fibrinopurulent, dense, collé à la paroi ef pouvant obstruer tout le conduit nasal dans les cas graves. II se rencontre également dans les sinus.

Cette congestion, ces pétéchıes et ces dépôts purulents se retrouvent jusque dans la trachée. Par contre ce n'est que lorsque la mort est due à une pneumonie bactérienne secondaire que les poumons sont atteints; en règle générale, ils sont normaux. 
2. Microscopiques. On retrouve dans les muqueuses touchées des lésions d'œdème, et la sous-muqueuse est infiltrée de lymphocytes et de macrophages. Mais le fait le plus saillant est la présence d'inciusions intranucléaires éosinophiles du type A Cowdry dans les cellules de la muqueuse nasale : elles sont d'apparition précoce mais de peu de durée et ne sont bien mises en évidence que sur les coupes fixées au Bouin et non au formol.

Pronostic. - Il est plus grave économiquement par le nombre d'animaux qu'il touche, la perte de poids qu'entraîne la maladie, la longueur de la convalescence, que par la mortalité.

Diagnostic. - I. Diagnostic clinique. Dans les régıons où sévił habiłuellement la maladie, le diagnostic est aisé. II repose sur la constatation d'une hyperthermie brutale qu'accompagne un catarrhe nasal abondant, de la congestion des muqueuses nasales et de la dyspnée.

Dans les régions où elle n'a pas encore été signalée, on éliminera :

La nécrobacillose à forme laryngée, de diagnostic difficile lorsque ne coexistent pas les lésions buccales. La contagion renseignera utilement : grande dans les cas de $\mathrm{RBl}$, cas disséminés dans le cas de nécrobacillose.

L'entérite d̀ virus, la peste bovine ont des tropismes plus nettement intestinaux.

La fièvre de transport pose un cas délicat, mais l'atteinte pulmonaire est plus intense.

Dans le coryza gangréneux, il y a un état de « tuphos » initial qui n'existe pas dans la RBI. Les symptômes oculaires, puis encéphalitiques, la douleur à la percussion de la tête, l'évolution toujours mortelle en 48 heures à 12 jours sıgnent le coryza gangréneux qu évolve par ailleurs par cas sporadiques.

2. Diagnostic expérimental. II repose sur :

- l'isolement du virus, relativement aisé en cultures cellulaires à partir du liquide de sécrétion nasal ou d'un écouvillonnage des fosses nasales. Ces liquides seront additionnés de 1.000 unités de pénicilline et $1.000 \mu \mathrm{g}$ de streptomycine parł millilitre et envoyés sous froid au laboratoire. L'ensemencement sur cellules de rein d'embryon de veau, la constatation des lésions cytopathiques et de leur inhibition par un immunsérum authentifieront le virus.

- les méthodes immunologiques, qui en comparant la teneur en anticorps neutralisant de deux prélèvements de sérums (I'un à l'acmé de la maladie, l'autre trois semaines plus tard), mettront en évidence une montée des anticorps.

Etiologie. - 1. Motières virulentes. Seules les sécrétions nasales sont virulentes. Le sang, la rate, ne le sont jamais.

2. Résıstance du virus. II n'a pas de résistance dans le milieu extérieur et s'il est déposé sur les fourrages, ces derniers doivent venir très rapidement en contact avec des animaux sains pour pouvoir véhiculer le contage.

3. Réceptivité. Seule l'espèce bovine est réceptive.

L'influence de la race est incertaine et si l'on accuse une plus grande réceptivité des races à viande, cela doit tenir au mode d'élevage. Expérimentalement, les veaux des races laitières se sont révélés très sensibles.

Le sexe n'a aucune influence. L'âge dort en avoır peu, et la raıson invoquée plus haut (les animaux que l'on engraisse sont de jeunes adutes) explıque la prévalence dans ce groupe d'âge. Expérimentalement les veaux de six semaines se sont montrés réceptıfs.

4. Modes de contogion. La RBI est contagieuse ef se transmet d'anımal ì animal dans les parquets d'engraissement des feed-lots. La maladie suit généralement l'introduction dans le troupeau d'un cas subclinique, mas ıl est fort probable égalemenf qu'existent d'authentiques excréteurs de virus, anciens malades guéris, qui entretiennent le virus en un site organique autre que les cavités nasales (muqueuse vaginale chez les femelles, où elle donnerait les symptômes frustes d'une vaginite granuleuse). Sous l'action de stress divers (transport, changement alimentaire), ils excréteraient leur virus et contamineraient leurs congénères. 
5. Votes de pénétration. Dans les conditions naturelles comme dans les conditions expérimentales, la voie nasale semble être la seule voie de pénétratıon du virus.

Prophylaxie, - Les recommandations de prophylaxie sanitaire, difficiles à mettre en œuvre, semblent illusoires à formuler.

Une immunité solide, de deux ans au moins de durée, suit la maladie ; les bovins sont alors réfractaires, soit à la maladie naturelle, solt à la maladie expérimeritale. C'est sur cette constatation que se fondent la prophylaxie médicale ef l'application de la vaccination. Les vaccins employés sont de deux types.

I. Vaccin vivant. Le virus de la RBI, cultivé sur cellules de rein d'embryon de veau, cellules de rein de porc ou de chien, confère l'ımmunité sans reproduire la maladie clınıque quand on l'inocule par vore intramusculare. Les vaccins ainsi préparés sant présentés sous forme lyophilisée. Ils sont d'une Innocuité et d'une efficacité parfaites. La vaccination des bovins d'embouche de l'ouest des Etats-Unis, est maintenant généralisée.

2. Vaccin inactivé. Le virus est cultıvé en cellules bovines de la même manıère que pour le vaccin vivant, puis il est inactivé par le formol et combiné à un adjuvant de l'immunité (adjuvant de Freund). Ce vaccın seralt plus spécialement destiné aux vaches reproductrices car le vaccin vivant a été accusé, à tort semble-t-il, de provoquer parfois l'avortement.

Traitement. - Les antibiotiques sont indiqués pour lutter contre les infections bactériennes secondaires et éviter l'atteinte du poumon.

Des antihistaminiques seront injectés pour diminuer la congestion nasale et des irrigations de préparations enzymatiques (dornase pancréatıque) afin de fluidifier les sécrétions et dıgérer les débris, seront faites localement.

\section{2. - CORYZA GANGRÉNEUX}

Le coryza gangréneux des bovidés est mondialement connu ; il existe en Afrique, tout spécial ement en Afrique orientale et mérıdionale. C'est avec l'entérite à virus, la maladıe qui offre le plus d'analogies cliniques avec la peste.

Diagnostic épizootiologique. - Il esł extrêmement rare de voir le coryza gangréneux évoluer par foyers ou sous forme de petites épizootıes. On ne rapporte ordinairement que des cas isolés, à tel point que l'on a pu dire de cette maladie qu'elle était infectıeuse et non contagieuse. Si la morbidité est basse, la mortalité est par contre très élevée, 'dépassant 90 p. 100

Le coryza gangréneux se rencontre avec plus de fréquence là où le bétail est mélangé aux moutons; la maladie inapparente du gnou a été décrite.

Diagnostic clinique. - En Afrıque, le coryza gangréneux évolue plus volontiers sous la forme oculo-rasale, sans complications digestives, ni nerveuses (planche 3).

Le début en est brutal et sidère l'anımal, qui présente les sıgnes des grandes septicémies; I'hyperthermie est élevée (400 5), durable tout au long de la maladı, ce qui est un premier signe distınctif de la peste. Apparaît une congestion très violente des muqueuses visibles de la tête : oculaire, nasale et buccale. Un jetage oculo-nasal s'établit, d'abord séreux puis muco-purulent. Le jetage oculaire s'épaissit vite, donnant des placards crustacés dans l'angle interne de l'œll tandis que se développe une kératife qui opacifie la cornée. Le jetage nasal devient de plus en plus abondant, filant, strié de sang ef contenant des fausses membranes. Il adhère aux naseaux et au muffle dont il entraîne l'exfoliation superficielle. Une toux rare peut se faire entendre.

L'abattement est intense. La percussion des sinus est très douloureuse et la palpation des cornes entraîne des mouvements de défense. On peut assister à la chute de l'étui corné.

Des ulcères semblables à ceux vus dans la peste peuvent se rencontrer dans la bouche, sur les gencives ef tout spécialement sur le plancher buccal. 
PLANCHE 6.
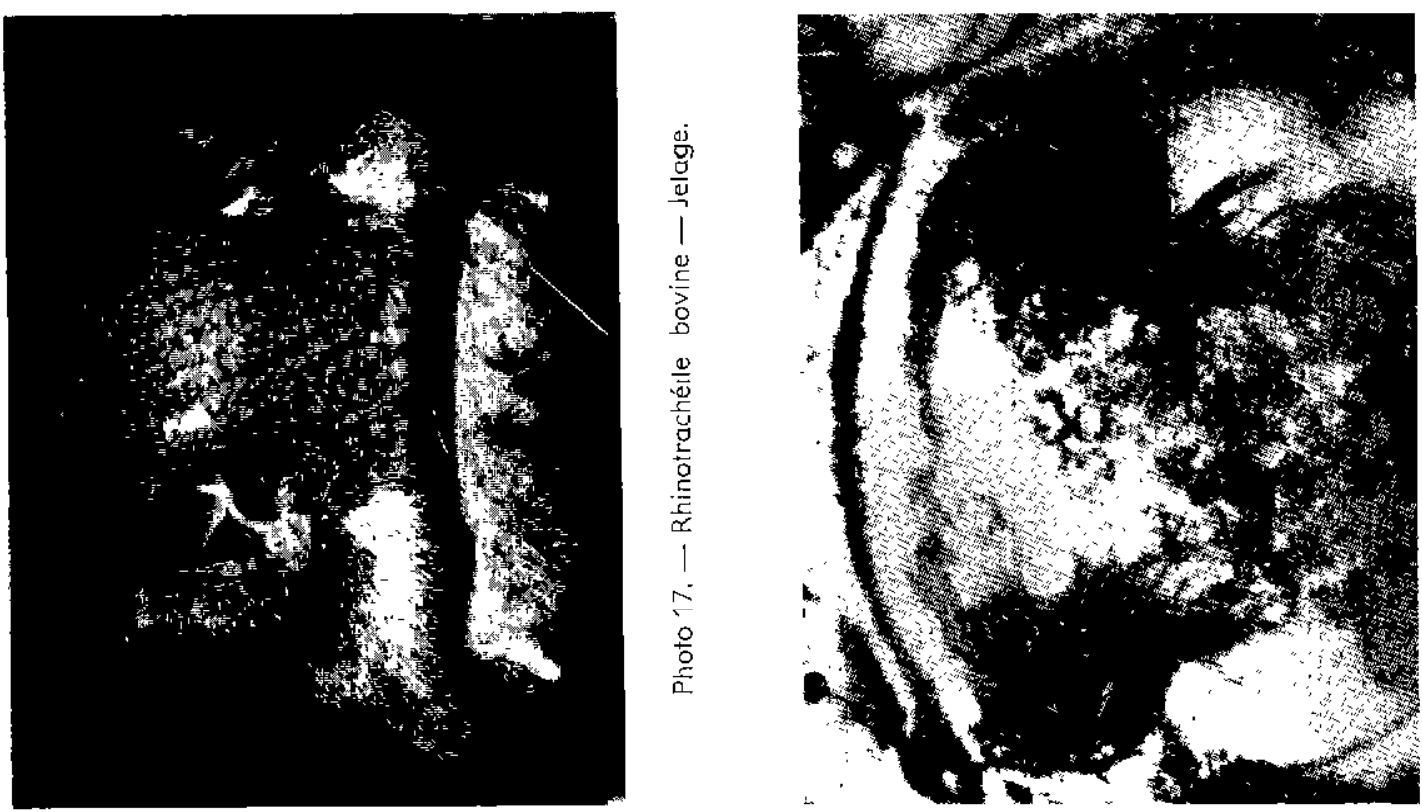

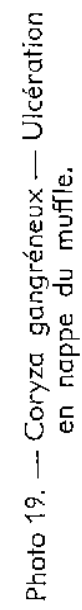
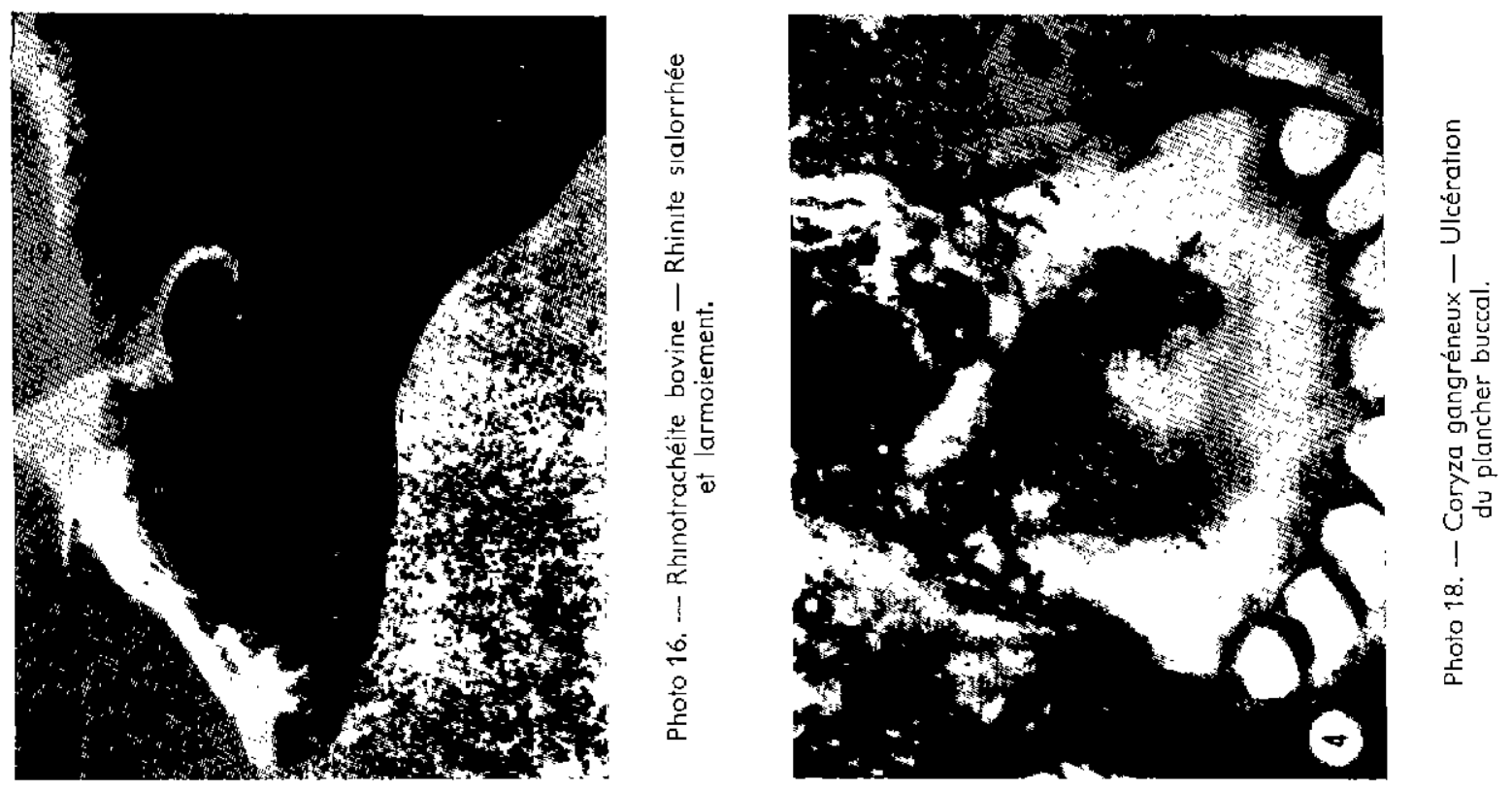

Photo 16 : extraite de Am J vet. Res. 1957, 18 (67) : 246-56.

Photo 17 : extraire de Dtsch. tierärtzti. Wochr.

Photos 18 et 19 : extraites de J. om. vet. med. Ass, 1958, 132 (6) : 243-B. 
Les ganglıons lymphatiques grossissent énormément et sont visibles de loin, d'autant plus que l'amaigrissement est intense bien que l'appétit se conserve longtemps.

La mort est la terminaison quasi inéluctable. II n'y a protiquement jamais de diarrhée. La maladie dure de dix à douze jours.

La diarrhée existe dans la forme intestinale où les symptômes naso-oculaires sont plus discrets. Le diagnostic clınique différentiel de cette forme avec celvi de la peste bovine est pratiquement impossible àfaire ; il repose uniquement sur l'absence de contagiosité.

En pratique, le diagnostic clinique du coryza gangréneux 'est basé sur l'abondance et la ténacité du jetage oculo-nasal, sur la kératite (qui n'existe dans la peste que lorsque cette dernière se complique de trypanosomiase), sur l'hypertrophie ganglionnaire.

Diagnostic nécropsique. - La maladie peut là encore en imposer pour de la peste.

On retrouve une congestion générnlisée de toutes les muqueuses de la tête. Les cavités nasales sont remplies de dépôts caséeux qui recouvrent des érosions muqueuses. II en est de même dans les sinus frontaux, le pharynx, la trachée. Toutefois, contrastant avec ces atteintes, le poumon est macroscopiquement normal.

Sur la muqueuse de la caillette, on note de petites hémorragıes ainsi que de pețits ulcères cratériformes à centre noir.

Le reste du tube digestifest normal, en particulier n'existent pas les lésions de la valvule ıléo-cacale, ni la rectite hémorragique de la peste.

La surface de section des ganglions lymphatiques est rougeâtre. Des granulations blanchâtres se rencontrent dans le foie ef les reins et dans ces derniers organes, on note une hypertrophie des corpuscules de Malpighı qui donnent une apparence granuleuse à la coupe.

Le cerveau parait « cuit » et a une odeur de bouillon.

Diagnostic expérimental. - L'inoculation intraveineuse d'une grande quantité de sang (au moins $300 \mathrm{ml}$ ) à un veau reproduit la maladie. On peut également inoculer un lapin.

Sur le cadavre, prélever des fragments de fole, de rein et de cerveau que l'on place dans le fixateur pour examen histologique (infiltration périvasculaire).

\section{3. - FIÈVRE DES TRANSPORTS}

Cette maladie n'est pas connue jusqu'à maintenant en Afrique centrale et occidentale. Essentiellement respiratoire (rhinite et bronchopneumonie), elle ne scurait être confondue avec la peste.

\section{E. - AFFECTIONS TOUCHANT LA MUQUEUSE DE LA CAILLETTE}

Nous citerons pour mémoire :

- L'helminthiase à Haemonchus contortus lorsque l'infestation est réellement massive,

- Les traitements anthelminthiques par des produits irritants et en particulier par des phénothiazines impures,

- la Théilériose à Theilerio parva ou East Coast Fever, celle à Theilerıa lawrencı ou Corridor disease. Ces deux protozooses n'existent pas en Afrique centrale et occidentale. Dans les régions infectées, elles peuvent être confondues cliniquement avec une peste bénigne : fièvre, larmoiement, salivation, diarrhée. Mais l'atteinte du poumon par cedème pulmonaire est constante dans la théilériose, ef l'animal réagit fortement aux excitations contrairement à ce que l'on voit dans la peste. A l'autopsie, on note des suffusions sanguines tout au long du tube digestif, mais elles existent également ailleurs : rein, graisse pelvienne. Des ulcères sont présents dans la caillette. Le poumon est invariablement touché ef contient un liquide séreux.

- La trypanosomiase aigue, et tout spécialement celle à Tryponosoma vivax, montre à l'autopsie des hémorragies des plis de la callette et dans le duodénum; on les retrouve aussi dans les muscles 
abdominaux, la graisse péri-rénale, sur toutes les séreuses, sur les oreillettes et la crosse aortıque. Un épanchement péricardique est fréquent. II n'y a pas d'ulcères buccaux, ni de rectite.

\section{F. - AFFECTIONS TOUCHANT LA MUQUEUSE INTESTINALE}

II n'y aurait aucune difficulté à éliminer cliniquement l'entérite paratuberculeuse (maladie de Johne). Les cas en sont très rares en Afrique centrale ou accidentale. Est-ce réellement une maladie peu répandue ou non diagnostiquée?

La coccidiose bovine se présente comme une diarrhée aiguë, striée de sang, rapidement débilitante. Mais il n'y a jamais de fièvre, ni d'ulcères buccaux.

Elle peut être assaciée à la peste dont elle est un facteur aggravant. La présence de kystes dans les fèces d'un bovin n'élimine pas la peste.

La bılharzıose intestinale est asymptomatıque chez le zébu ; ce n'est qu'une trouvaille d'autopsie. 


\section{3e PARTIE}

\section{DIAGNOSTIC EXPÉRIMENTAL DE LA PESTE BOVINE}

Le recours au diagnostic expérimental s'impose de nos jours aussi bien en pays neuf qu'en pays infecté :

- En pays neuf, parce que la suspicion épizootıologique, clinique ou nécropsique de peste bovine pose des impératifs sanitaires si graves que le laboratorre se doit d'apporter une certitude. Sa rapidité d'intervention devrait éviter que ne se reproduisent les incidents de 1920 en Belgique ou de 1949 en Italie.

- En pays d'enzootse, parce que prédominent maintenant des formes atypiques, que se fait jour une pathologie nouvelle qui n'est pas sans rappeler la peste, et que la contamination d'espèces irrégulièrement réceptives, dont singulièrement les chèvres, prend de plus en plus d'ampleur. Le succès des campagnes d'éradication actuellement menées, demande qu'un diagnostic exact soit posé ; c'est ivi qui permettra de suivre ou de comprendre une épizootiologie qui peut rester équivoque par sa seule expression clinique.

Le diagnostic expérimental de la peste bovine vise à mettre en évidence :

- dans les tıssus ou humeurs d'un animal infecté, le virus bovipestıque (ou l'un de ses constituants),

- ou bien la trace sérologique de son passage,

- ou bien sa trace lésionnelle dans les tissus, par la recherche des lésions spécifiques de l'infection pestique.

II est bien évident alors que les deux premières recherches peuvent être menées sur l'animal vivant ou sur le cadavre, la dernière ne sera qu'un complément de l'autopsie.

Les méthodes se basant sur la recherche de l'allergie n'ont pas encore fait la preuve de leur valeur.

\section{i. - Diagnostic histologique}

Le diagnostic histologique ne peut être mené qu'à partir des prélèvements effectués sur un cadavre.

Il est basé sur la reconnaissance, dans les épithéliums et tissus touchés par le virus, de cellules multinucléées (plasmodes ou syncitiums) et d'inclusions intracytoplasmıques et intranucléaires. Cette trilagie lésionnelle, à l'exclusion de toute autre, a seule valeur de certitude.

Elle se rencontre dans :

- I'assise génératrice (corps muqueux de Malpighi) des épithéliums pavimenteux stratifiés : cavité bucco-pharyngienne, amygdale, muqueuse vulvaire et du fourreau, conjonctive palpébrale, orifice nasal.

- les tıssus lymphoïdes : ganglıons lymphatiques, follicules lymphoides des plaques de Payer de l'intestin, où leur reconnaissance peut être obscurcie par les lésions de dégénérescence concomitantes.

Les prélèvements seront effectués et envoyés au laboratoire spécialisé aınsi qu'il est exposé dans la fiche technique $n^{\circ} 2$.

En tout état de cause, le diagnostic histologique de la peste bovine demande une très grande technicité, et seuls quelques laboratoires sont susceptibles de faire cette recherche *.

\footnotetext{
* En Afrique francophone, envoyer les prélèvements au Laboratoıre de recherches vétérinaires de Farcha FortLamy, Tchad, ou à celui de Hann, Dakar, Sénégal.
} 
Après exécution des coupes, seront pratiquées les colorations à l'hématoxyline-éosine ou au trichrome de Masson, celles de Mann et d'Altmann.

Les plasmodes multınucléés seront recherchés sur les coupes colorées à l'hématoxyline-éosıne, en insistant sur celles provenant des prélèvements de muqueuses épithéliales; les inclusions intracytoplasmiques et éventuellement intranucléares sur celles des amygdales ef des formations lymphatiques (planche 7).

Les coupes de muqueuse nasale colorées par l'hématoxyline-éosine permettront de poser le diag. nostic histologique de rhinotrachéite infectieuse bovine par la reconnaissance d'inclusions intranucléaires du type A de Cowdry, tandis que les coupes de cerveau et de foie pourront farre pencher pour le coryza gangréneux si l'on y note des foyers d'infiltration périvasculaıre que l'on rencontre dans cette maladie.

Une recherche négative ne peut en aucun cas éliminèr le diagnostıc de peste bovine. II est en effet des souches de virus qui ne donnent que de très petits plasmodes épithéliaux. En d'autres cas, la maladie peut être trop avancée et les lésions spécifiques seront obscurcies par les lésıons de nécrose ou de remaniement. En conséquence, devront toujours être tentées à partir du cadavre les autres méthodes expérımentales du diagnostic qu sont l'isolement du virus ou son identification par les techniques de fixation du complément ou de précipitation-diffusion en gélose.

\section{I1. - DIAG NOSTIC VIROLOGIQUE}

II se base soit sur la reproductıon de la maladie clınique chez un hôte sensible, soit sur l'isolement et l'identification du virus en cultures cellulaires.

\section{A. Reproduction de la maladie}

C'est la plus ancienne des méthodes de diagnostic expérimental de la peste bovıne. C'est elle que l'on employait en Afrique pour s'assurer du diagnostic. C'est pourtant elle qui peut être la plus sujette à caution de nos jours par suite de la difficulté de trouver des animaux à coup sûr sensibles, et de l'existence de souches de vırus naturellement atténuées ne dorinant qu'une symptomatologie fruste.

En pays neuf, où l'approvisionnement en bovins sensibles ne fait pas défaut, elle est entravée par la crainte de provoquer un foyer nouveau à partir de l'animal inoculé ; on n'y aura donc recours que sı l'on a d̀ sa disposition des étables d'isolement spécialement conçues pour l'étude des virus. II ne peut qu'être déconseillé d'y faire appel dans le cas contraire.

Choix des bovins. II ne se pose pas en pays neuf.

En région d'endémicité soumıse à une prophylaxıe intensive, deux alternatıves s'offrent à l'expérimentateur : Importer et constituer un stock de bouvillons sensibles venant d'un pays neuf; ou bien acheter des veaux âgés de dix mois environ, ne portant aucune marque distinctive de vaccination, et les saigner en vue de la recherche d'éventuels anticorps neutralisants (voir fiche technique no 4) ; on ne retiendra que ceux qui en sont dépourvus.

II serait particulièrement déconseillé d'effectuer un diagnostic de peste par inoculation si l'on n'était pas tout à faitsûr de la réceptivitée des animaux; c'est, à notre avis, la plus lourde hypothèque qui pèse sur la méthode.

Quatre veaux sont nécessaires. Deux seront inoculés avec le matériel infecté, deux autres auront été inoculés au moins quinze jours auparavant avec l'un des vaccins antipestiques actuellement existants (à l'exclusion d'un vaccin inactivé qui demande un trop long temps pour que s'établisse l'immunıté, brève d'ailleurs dans sa durée).

Prélèvements. On prélève

a) sur un animal abattu ou un cadavre frais, les ganglions lymphatiques (en excluant les ganglıons mésentériques, sauvent fortement contaminés par des germes de soullure);

b) sur un animal malade, du sang citraté, héparıné ou additionné de versène (voir fiche technique no 3 ). 
Les prélèvements sont placés dans des récipients étanches; toutes indications utiles y sont portées; une fiche de renseignements est remplie (fiche technique $n^{0} 1$ ).

Si l'on a à convoyer ou expédier les prélèvements, les envoyer sous froid, en boîte isotherme avec une quantité suffisante de glace. Les prélèvements de ganglions lymphatiques peuvent être congelés, mais le sang ne devra jamais l'être sous peine de destruction rapide du virus; il sera conservé ef envoyé dans la glace fondante.

Inoculation. On décapsule les ganglions et on les découpe (une partie aliquote est conservée pour effectuer une précipitation-diffusion en gélose)*; on les broie (mortier, pilon et sable ou mixer) dans environ 10 fois leur poids de sérum physiologique glacé ; on a intérêł à ajouter 1.000 unités de pénicilline et $1.000 \mu \mathrm{g}$ de streptomycine par millilitres. Après centrifugation, on inocule 10 millilitres de surnageant par vole sous-cutanée aux quatre veaux (deux réceptifs, deux immuns). Le sang sera inoculé directement par voie sous-cutanée.

Observation. Les veaux inoculés sont placés dans les box d'isolement. Un personnel spécial s'occupera de les affourager, et toutes précautions seront prises pour éviter les «fuites 》 de virus.' Les températures seront relevées chaque matin. Toute élévation thermique entraînera un examen clinique détaillé et la confection d'un frottis de sang pour la recherche d'éventuels hémoparasites.

Si le virus bovipestique est présent dans les prélèvements, la maladie apparaît chez les seuls veaux non vaccınés dans un délai de trois à douze jours.

La constatation d'une fièvre diphasique accompagnée ou non de diarrhée et d'ulcérations buccales doit faire suspecter une diarrhée à virus. II est alors possible que les veaux immunisés par le vaccin la présentent aussi. On devra tenir dans ce cas la même conduite que celle dont nous parlerons maintenant.

S'Il n'existe que des signes équivoques (diarrhée sans lésions buccales, larmoiement sans diarrhée, diarrhée sans hyperthermie...), on devra pratıquer la recherche de l'antigène pestique par ponction-

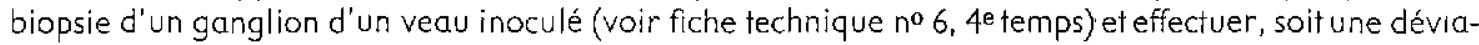
tion du complément (fiche technique $n^{0} 5$ ), soit une réaction de précipitation-diffusion en gélose (fiche technique $n^{\circ} 6$ ). Dans le cas où les signes clıniques de peste bovine ne s'affermissent pas, sacrifier l'un des veaux et effectuer les deux recherches précitées sur ses ganglions lymphatiques. L'autre sera saıgné quinze jours après et sur son sérum sera effectuée la recherche des anticorps antipestiques (vide infro: Diagnostic sérologique, et fiche technique no 6).

C'est dire que de sérieuses limitations sont maintenant imposées à une technique simple qui connut autrefois la faveur des expérimentateurs. C'est dıre aussi que le diagnostic de peste mené dans ces conditions et faisant appel à une technicité poussée relève de laboratoires bien équipés ;

Variante du procédé. Au lieu d'inoculer des veaux sensibles, on peut avec avantage inoculer des chèvres. Etant donné la réceptivité variable de ceffe espèce selon les races et les individus, eu égard également aux mortalités non spécifiques qui arrivent lorsqu'on garde des chèvres en stabulation, c'est douze animaux que l'on devra sélectıonner en vue du dıagnostic; ils seront saignés et leurs sérums conservés pour être examinés plus tard.

Les conditions ef le traitement du prélèvement seront les mêmes. Deux chèvres seront inoculées avec un virus-vaccin capripestique pour avoır une idée de la réceptivifé à la peste du lot de chèvres achetées : une au moins devrait réagir. La peste d'origine bovıne étant bien souvent asymptomatique chez les chèvres, la clinique renseignera dans bien peu de cas, mais la recherche de l'antıgène pestique ou des anticorps antipestiques tranchera la queshion : ces deux recherches seront menées dans les mêmes conditions que celles que nous avons évoquées pour le veau.

Cette variante n'a été encore qu'assez peu expérimentée. Elle a l'avantage de pouvour être à la portée des stations décentralisées; la technique employant l'inoculation à la chèvre suivie de la recherche de l'antıgène pestique chez cet anımal sembleraıt particulièrement recommandable.

* On peut se demander à quoi serl d'effectuer une recherche virologique longue et coûteuse alors que la precipıtation en gélose est simple et économique ; c'esi qu'il peut exister une dissociation ainsi que nous l'exposerons plus loin. 


\section{B. Isolement et identification du virus en cultures cellulaires}

C'est à notre sens le procédé de cholx.

Avantages : - d̀ faible prix de revient par rapport à l'ınoculation au veau sensible ;

- commodité de la manipulation ; suppression des box d'isolement et des précautions pour l'affouragement :

- pas de risques d'infections intercurrentes, notamment de fièvre aphteuse qui aurait pu être clınıquement confondue avec la peste lors des prélèvements ;

— sécurité de la réponse, corollaire de l'utilisation de cellules à réceptivité totale, contrastant avec la sensıbilité douteuse des veaux en région d'endémicité :

- sensibilité, pour le diagnostic tout au moins, égale d̀ celle du veau.

Inconvénients : - Technique réservée à un laboratoire très bien outıllé ; cet argument tombe d'ailleurs si l'on se rappelle les objections que nous avons mises en avant quant à l'approvisionnement en veaux sensibles, la réceptivité des animaux devant être mise en évidence.par une séro-neutralisation.

Prélèvements. lis seront effectués selon les indications portées sur la fiche technique no 3 .

Les ganglıons seront de préférence prélevés sur un anımal abattu, plutôt que sur un cadavre mort naturellement. Si l'on ne peut disposer que de cadavres, prélever ceux de la tête (préparotidien, sousmaxillaires, rétropharyngien). Les instruments devront avoir été désinfectés (ébullition prolongée, au minimum) ; on se servira d'instruments différents pour inciser la peau et pour détacher les ganglions des fascid conjonctifs.

Placer les ganglions dans des récipients stériles (ou maintenus pendant 20 mınutes au moins dans l'eau bouillante, puis refroıdis après avoir été fermés). N'ajouter aucun antiseptique. Réfrıgérer immédiatement dans la glace. Envoyer au laboratoire, accompagner d'une fiche de renseignements, sans rupture de froid et dans les meilleurs délais.

Les ganglions peuvent être congelés.

Le sang sera prélevé sur un animal vivant, cliniquement suspect, on se conformera aux indications de la fiche technique $n^{\circ} 3$. Ne jamais congeler le sang ; l'expédier dans la glace fondante.

Après broyage des ganglions au 1/10 en tampon P. B. S. additıonné d'antibiotiques, le labaratoire procédera à un cycle de gel-dégel sur le broyat, suivi d'une centrifugation. Une partie aliquote sera de nouveau diluée au $1 / 10$ en lıquide de Hanks. Cette dilution servira à infecter :

10 des cellules de rein d'embryon de veau fraîchement préparées (l partie de broyat pour 9 partıes de cellules dans le milieu de croissance contenant 10 p. 100 de sérum de veauxréceptifs à la peste). Après séjour d'une heure à $37^{\circ}$ pendant laquelle sont faites de fréquentes agitations, la suspension cellulaire est répartie en tubes cylindriques ou mieux en tubes de Leighton contenant des lamelles,

$2^{\circ}$ des cellules identiquement préparées mais mises en suspension dans le milieu de croissance contenant 10 p. 100 de' sérum d'un veau immun de peste bovine. Le traitement ultérieur est le même.

Après renouvellement du milieu de culture au bout de deux jours, suivi de renouveliements tous les deux jours, les tubes seront observés à partir du $4 \mathrm{e}$ jour après l'inoculation, puis tous les jours pendant dix jours. Le diagnostıc peut être porté dès le $4^{\mathrm{e}}$ jour lorsqu'apparaîtront dans les tubes inoculés et ayant reçu le sérum normal les effets cytopathiques (plasmodes multinucléés), qui seront absents dans les tubes ayant reçu le sérum immun (planche 4).

Le sang arrivant au laboratoire sera centrifugé, la fraction leucocytaire récoltée, lavée et mise en culture dans les mêmes conditions que les ganglions.

La valeur du diagnostic ainsi porté sera fonction de la correction avec laquelle ont été faits les prélèvements et de leur frâ̂cheur, de la rapidité de leur transmıssion. L'un des grands avantages de la culture cellulaire est qu'elle esł apte à détecter les souches hypo-virulentes qui pourraient ne do nner par inoculation au veau, que des symptômes frustes ou équivoques. 


\section{III. - diAg NOSTIC SÉROLOgiQUE}

Roppels prélıminares : on définıt par antigène toute subsłance étrangère à un organisme qui, introduite par voie parentérale dans cet organisme, y détermine la formation d'anticorps.

On définit par anticorps des globulines sériques qui apparaissent dans un organisme quand s'y trouve introduite une substance étrangère dite antigène.

En principe, à chaque antigène correspond un anticorps qui lui est spécifique. Un antigène s'unit, se copule spécifiquement à l'anticorps correspondant lorsque tous deux viennent en contact ; ils forment alors ensemble un immun-complexe.

Por extension, le terme d'antigène est appliqué en sérologie aux substances que l'on introduit dans les réactions pour mettre en évidence les anticorps.

Le diagnostic sérologique de la peste bovine est basé sur deux recherches différentes :

- Ia recherche de l'antigène pestique dans le matériel suspect (ou chez le veau ou la chèvre sensibles inoculés de matêriel suspect, ainsi qu'il a été dit au chapitre: Dıagnostic virologique). Cette méthode est une méthode rapide, donnant à partir de prélèvements exécutés sur un cadavre, un animal abattu ou éventuellement un malade, sa réponse en quelques heures pourvu que l'on ait l'équipement et le matériel nécessaires,

- la recherche d'anticorps déviant le complément, inhibant la précipitation ou neutralisant dans le sérum d'animaux convalescents d'une maladie que l'on soupçonne avoir été la peste (ou ınoculés avec un matériel suspect ainsi qu'il est décrit au chapitre : Diagnostic sérologique). Cette recherche, par les délais qu'elle demande (temps entre la constatation de la maladie et les prélèvements de sérum) n'offre guère qu'un intérêł spéculatif quant au dıagnostic et ne peut être conseillée que pour des études épizootiologiques a posteriori.

\section{A. Recherche de l'anigène pestique}

Alors que, dans le diagnostic virologique, on cherchait à isolerle virus virulent, l'antigène que l'on met en évidence Icı n'est pas la particule virale infectieuse maıs l'antıgène « soluble » qui l'accompagne*.

Deux groupes de méthodes retiennent l'attention; ce sont la déviation du complément et la précipitation-diffusion en gélose. Toutes deux metfent en jeu le même « antigène soluble » viral ef le même anticorps sérique; seules changent les modalités techniques pour la mise en évidence de la formation (ou de son absence) de l'immun-complexe formé par l'union de l'antigène et de l'anticorps.

Dans la réaction de précipitation-diffusion en gélose, on donne à l'antigène soluble le nom de précipıtogène; ce terme ne désigne pas un antigène partıculıer ef n'est utilisé que par commodité.

Principes : Les deux réactions de précipitation en gélose et de déviation du complément sont basées toutes deux sur le même phénomène : la formation de l'immun-complexe entre l'antigène pestique soluble et son anticorps. Dans le cas qui nous occupe (dıagnostic de la peste bovıne par recherche de l'antigène pestique), l'anticorps est connu : c'est un immun-sérum de référence ; l'antigène mis sous test est l'inconnu.

Précipitation-diffusion en gélose : Dans un gel de gélose contenu dans une boite de Pétri, on creuse deux puits de quelques milımètre de diamètre, distants l'un de l'autre de quelques millimètres. L'un est rempli de l'immun-sérum antipestıque de référence, l'outre d'un broyat de ganglion pestıque. Les molécules de l'immun-sérum et de l'antıgène diffusent dans la gélose tout autour de leurs deux réservairs; là où elles se rencontrent se forme l'immun-complexe ; les molécules d'immun-complexe formées s'accolent les unes aux autres et étant présentes en grande quantité dans le gel, deviennent visibles et forment la bande de précipitation.

* Lors de la multiplication d'un virus, dans les cellules sensibles s'élaborent dans le cytoplasme et diffusent hors de la cellule en mêrme temps que le virus des «antıgènes solubles » qui ne sont pas par eux-mêmes d'essence virale, mais plutôt des témorns (by-products) de l'infection cellulaire par le virus 


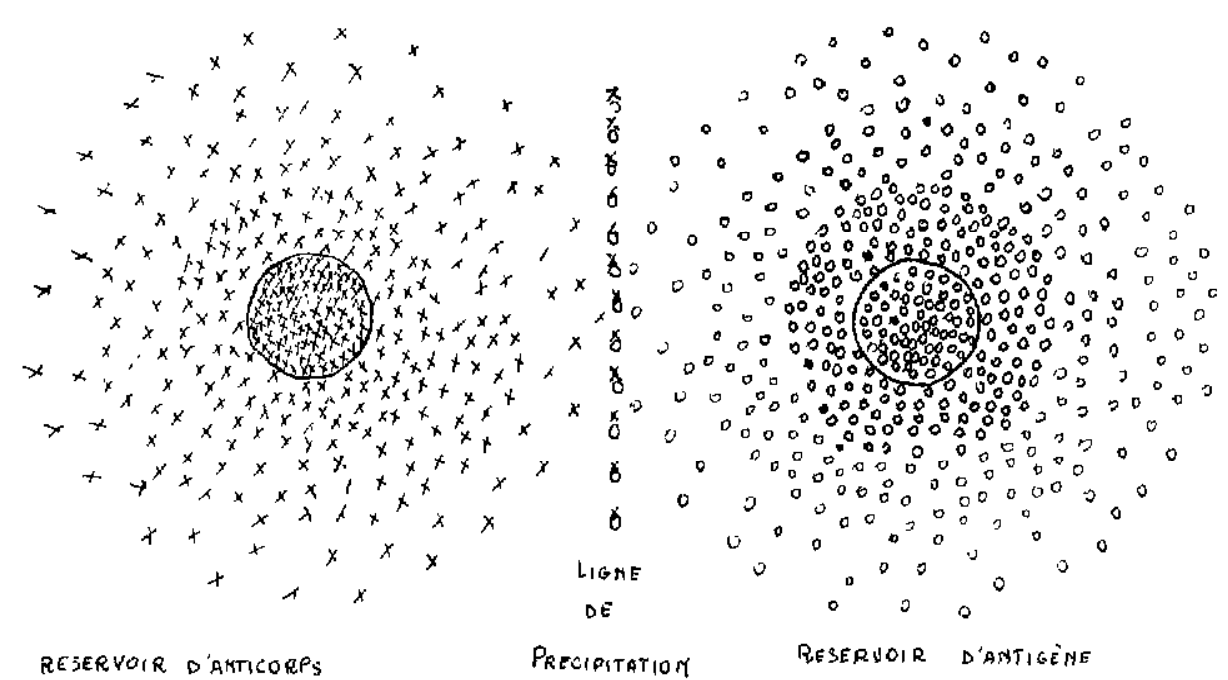

Fig. 1. - Précipitation - diffusion en gélose.

Déviation du complément. - Dans cette réaction, qui se fait en tubes, les deux réactifs sont très dilués; ayant lieu en milieu liquide, les molécules d'immun-complexe formées ne sont pos visibles. Pour les objectiver, on emplaie un artifice de laboratoire qui est basé sur le fait que les molécules d'immun-complexe formées adsorbent le complément (ou alexine contenue dans le sérum frais) de cobaye que l'on introduit dans la réaction. Ce complément éłant adsorbé sur l'immun-complexe, ne sera plus libre pour assurer la lyse d'hématies de mouton que l'on introduit ultérieurement dans les tubes sous forme de complexe lytique hématies de mouton-sérum hémolytique anti-mouton.
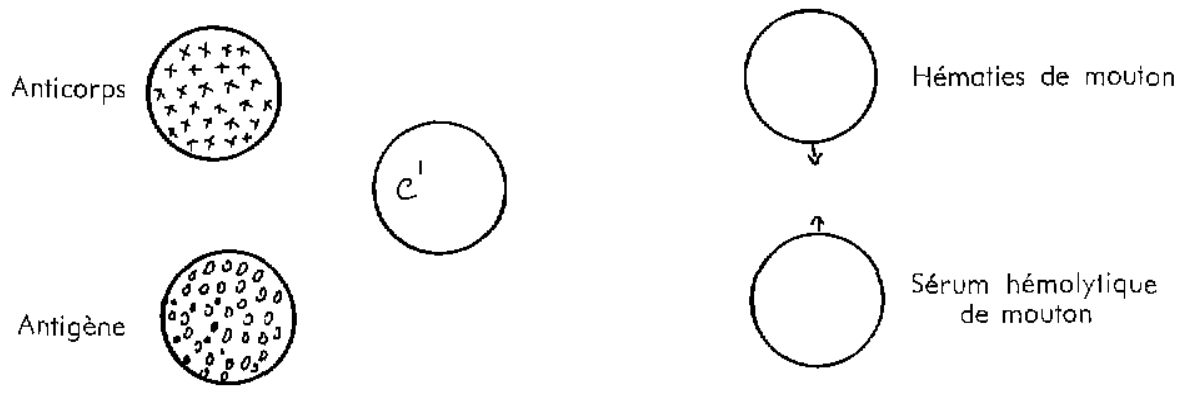

Fig. 2. - Schéma de la réaction de déviation du complément.

Dans le cas de réaction positive, il y a formation de l'immun-complexe (antigène pestique soluble + immun-sérum antipestique) qui adsorbe le complément. Célúi-ci n'est plus libre et il n'y a donc pas lyse des hématies de mouton : le tube contenant les réactifs reste trouble par suite de la présence d'hématies de mouton intactes.

Dans le cas de réaction négative, il n'y a pas formation de l'immun-complexe (immun-sérum antipestique + quelque chose d'autre qui n'est pas un antıgène pestĭque). Le complément reste libre et assure la lyse des hématies de mouton : le tube contenant les réactifs sera clair et contiendra une solution d'hémoglobine venant des hématies lysées.

Réalisation. Tous les détails sont donnés dans la fiche technique no 5 pour la déviation du complément et la fiche technique $n^{\circ} 6$ pour la précipitation-diffusion en gélose. 
On se rendra aisément compte que les méthodes de déviation du complément, par la technicité qu'elles requièrent, ne sont recommandées qu'aux laboratoires et aux personnes possédant une prałique des manipulations de sérologie. Parmi elles, notre préférence va à la technique de Cowan, dont l'antigène est facile à préparer (cet antigène pourrait d'ailleurs servir pour la précipitation-diffusıon en gélose) et la sensibilité très correcte pourvu que la fixation se fasse pendant dix-huit heures à $+4^{\circ} \mathrm{C}$ et non deux heures à 370 .

Par contre, la précıpitation-diffusion en gélose, simple à mettre en cuvre, ne de mande qu'un minimum de moyens. C'est une technique qui peut être mise entre les mains des vétérinaires de brousse. Bien qu'étant environ 100 fois moins sensible que la réaction de déviation du complément pour détecter l'antigène pestique, elle l'est tout de même suffisamment dans la pratique pour pouvoir rendre service et mérite d'être diffusée. C'est donc à elle principalement que s'adresseront les quelques commentaires qui suivent.

Spécificité, Les deux réactions sont spécifiques. SCOTT et BROWN (1961) confirment que sur 693 prélèvements provenant de 18 espèces, ils n'eurent aucune fausse réaction positive en précıpitation-diffusion.

Sensibilité. Elle est sous la dépendance de plusieurs facteurs:

1. La date de la récolte des ganglions après le début de la maladie. Des titrages d'antigène obtenus au cours de la peste expérimentale ont montré que son développement était maximal au $6 \mathrm{e}$ jour de la maladie. Si l'on collecte les ganglions servant à préparer l'antigène au premıer jour de la maladie

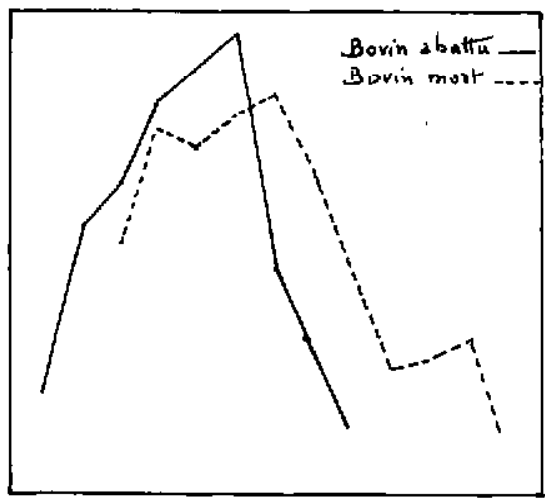

Fig. 3. - Evolution du précipitogène avec l'infection pestique.

En ordonnée: $\log 0-2$

En abscisse : jours après le début de la fièvre

(d'après SCOTT et BROWN)

(début de l'hyperthermie), on pourra poser un diagnostic négatif en précipitatıon-diffusion en gélose, alors que la déviation du complément et la recherche du virus seront toutes deux positives. La période optimale se situe dans les premiers jours de la maladie, avant même que n'apparaisse la diarrhée.

Les animaux pestiques qui ont une diarrhée persistant depuis plusieurs jours et qui sont déshydratés fourniront très probablement une réponse négative.

2. L'intensité de la maladie clinique. La précocité d'apparıtion des lignes de précipitation ainsi que leur netteté, est fonction de la gravité de la peste chez le bovin donneur de ganglions ; c'est dire que la sensibilité de la réaction est directement fanction de la virulence de la souche pestique en cause. Cette opinion, déjà émise par SCOTI et BROWN (1961), a été confirmée par nous-mêmes. II est difficile, avec les souches peu virulentes donnant une peste atypique ou asymptomatique, d'avoir des lignes de précipitation nettement visıbles. En présence de tels cas et si l'on soupçonne vraiment la peste, la sagesse demande que l'on envore au laboratoire spécialisé des prélèvements de ganglion lymphatique et de sang pour la recherche du virus en cultures cellulaıres.

3. La thermo-instabilıté du précipıtogène. SCOTT et BROWN (1961) ont précisé les limites d'activité de l'antigène (précipitogène) conservé à différentes températures : 


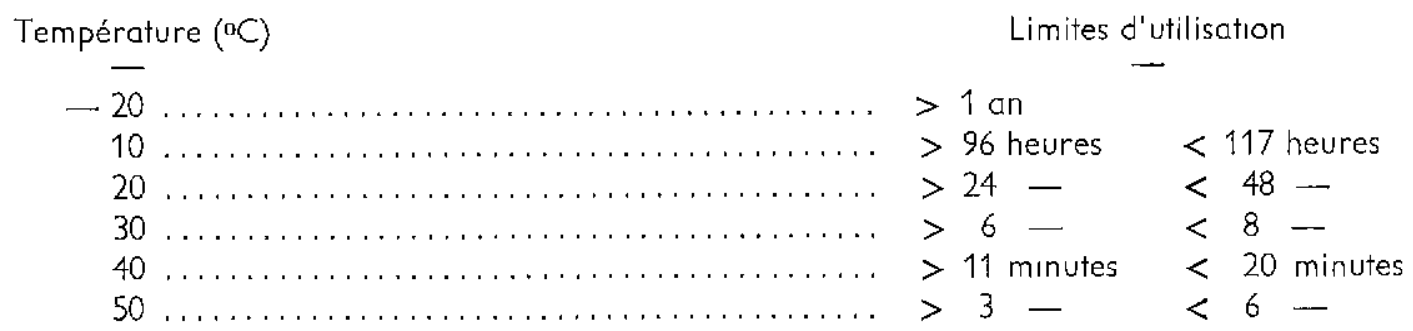

De là découlent deux impératifs:

a) la nécessité de préparer le broyat de ganglions devant servir à la réaction dans les quelques minutes suivant le prélèvement. Si l'on doit attendre quelque peu, conserver le ganglion dans un récipient étanche ımmergé dans la glace fondante. Lorsque le broyat est fait, exécuter immédiatement la réaction ou bien conserver ce brayat dans la glace fondante.

b) I'obligation de tenir compte de la température ambiante pour l'incubation des boîtes de gélose, une fois disposés les éléments de la réaction. Nous avons vu dans le tableau précédent qu'à $40^{\circ} \mathrm{C}$, température qu'il est assez fréquent de rencontrer en Afrıque centrale, il est inactivé en moins de 20 minutes. Si l'on opère dans des conditions météorologiques dures, il est nécessaire sous peine de nullité de la réaction :

- de conserver les réactifs, notamment l'antigène de référence et l'antigène suspect sous froid (freezer, réfrigérateur ou glace fondante),

- de réfrigérer (sans les congeler, ce qui les rendrait inutilisables) les gels de gélose coulés en boîtes de Pétri, avant d'effectuer la réaction,

- lorsque les réactifs sont répartis, de placer les boîtes dans un réfrigérateur ou un récipient isotherme contenant de la glace fondante. La réaction sera alors retardée de 24 à 36 heures, mais on ne courra pas le risque d'avoir un test rendu négatif par thermo-inactivation de l'antigène.

Malgré les limites que nous venons de lui imposer, le diagnostic de la peste bovine par la méthode de précipitation en gélose reste très valable, tout spécialement si l'on envisage plusieurs malades d'un même troupeau plutôt qu'un individu isolé. On peut attendre de la méthode 70 p. 100 de résultats posıtifs. La déviation du complément, plus sensible mais plus délicate, donnera des résultats positifs avoisinant 100 p. 100.

\section{B. Recherche des anticorps antipestiques}

Ainsi que nous l'avons déjà dit, cette recherche n'offre que l'intérêt du diagnostic a posteriori. Elle peut venir en complément des techniques d'identification virologique lorsque l'animal inoculé n'est pas mort (voir plus haut: Diagnostic virologique).

II est indiqué d'y faire appel lorsque, sur une population bovine neuve, I'on pense avoir a faire à un virus de virulence amoindrie : ce ne sera cependant qu'un complément de l'isolement du virus en cultures cellularres.

Princpe : Les infections virales déterminent, dans la grande majorité des cas, une apparition d'anticorps neutralisant le virus et déviant le complément avec l'antıgène viral. Pour ce quı est de la peste bovine, les anticorps neutralisant persistent un temps très long après la guérison (13 ans au moins après inoculation de virus capripestique) alors que les anticorps déviant le complémenł sont plus fugaces (quelques jours à quelques mois après la guérison). C'est la raison pour laquelle, en pratique, on recherche surtout les anticorps neutralisant le virus *.

* WHITE el SCOTT (1960) ont proposé une méthode de détection des anticorps chez les bovins convalescents par inhibition de la précipitation en gélose ; on peut faire à cette technique le même reproche qu'c̀ la déviation du complément : l'instabilité de ces anticorps in vivo. Paur cetle raison, elle n'a pas connu le succès qu'elle était en droit d'attendre de par sa simplicité. 
Pour ce faire, on met en présence sérum sous test (ou ses dilutions) et virus adapté à un système de culture choısı (bœuf, lapın, œuf, cultures cellulaires) puis l'on apprécie sur ce système l'absence ou la présence de virus, selon que le sérum aura ou n'aura pas d'anticorps neutralısants (voir fiche technique no 4).

Cette recherche n'a de valeur que si l'on peut titrer dans un examen comparatif la teneur en anticorps de deux échantillons du sérum du bovin :

- I'un prélevé avant la maladie ou à la phase aigue,

- l'autre prélevé tross semaines plus tard.

Ne faire de recherche que dans ce dernier prélèvement ne servirait à rien, car on ne pourrait à coup sûr rapporter à la peste (à moins que ce ne soit en pays neuf) la maladie qu'a présentée le bovin suspect.

Conditions du prélèvement: Les prélèvements de sang doivent être réalisés avec le maxımum de propreté, sinon d'asepsie, possible. On se conformera aux indications données par la fiche technique $n^{0}$ 7. Ne jamais ojouter d'antiseptiques aux prélèvements.

Réolisation : On a le choix entre plusieurs méthodes : celle qui emploie le lapin et le virus lapinisé, celle qui emploie l'œuf et le virus avianisé, celle enfin qui utilise les cultures cellulaires. Seules les premières et dernières méthodes ont retenu la faveur des expérımentateurs car les souches avıanisées sont parfois difficiles à propager et leur emploi pour la séro-neutralisation reste aléatoire.

Les méthodes de séro-neutralisation sur lapin (5COTT ef BROWN; HUARD ef ANDRÉ) sont relativement aisées à réaliser. Elles sont décrites en détail dans la fiche technıque no 4 . La recherche des anticorps en cultures cellulaires a toutefois notre préférence parce que la moins coûteuse et la plus propre à la standardisation.

Résultats : La réponse est spécifique (pourvu que l'on ait pu comparer deux prélèvements d'un même sérum) et d'une bonne sensibilité. Elle exige malheureusement des délais incompatibles avec les nécessités d'une action sanitaire rapide. 


\section{4e PARTIE \\ LA CONDUITE dU DIAGNOSTIC: CHOIX D'UNE MÉTHÓdE}

Au terme de cette revue des mayens du diagnostic de la peste bovine, nous devons en apprécier la valeur respective.

1. En pays normalement indemne, si la peste bovine éclate accidentellement (en dehors de la zone d'enzootie ou enclave d'élevage fermée en zone d'enzootie), les bases et les moyens du diagnostic seront :

- l'épizootiologie : affection envahissante, très contagieuse, à morbidité et mortalité élevées,

- les signes cliniques sur lesquels nous n'ınsisterons pas,

- les lésions relevées à l'autopsie qui entraîneront la certitude pour peu que l'observateur soit averti.

Le diagnostic expérımental, par les réactions de déviation du complément ou de précipıtationdiffusion en gélose, apportera en quelques heures la confirmation de la suspicion.

intangible pour ce qui est des souches pleinement virulentes, cette conduite du diagnostic doit également tenir compte des souches atténuées dont la pluralité se fait jour, et qui pourraient infecter un bétail sensible. Nous avons déjà dit qu'elles se caractérisaient par la fugacité des lésions buccales qu'elles déterminaient, l'absence de diarrhée et la très faible léthalité. Aucun incident de ce genre ne s'est encore manifesté, mais s'il se produisait, ne serait-on pas tenté d'invoquer d'abord une entérite à virus avant que de penser à la peste ? En ces cırconstances, et plutôt que de se fier au flair clinique du vétérinaire, s'impose le diagnostic expérimental.

Par ordre de sensibilité décrolssante, on classera les différentes méthodes du diagnostic expéri. mental :

- démonstration des anticorps spécifiques dans des échantillons de sérum. Sera utilisée l'une des techniques de séro-neutralisation indiquées dans la fiche technique no 4 ; la technique utilisant la séroneutratisation en cultures cellulaires, réalisable intégralement in vitro, doit remporter les suffrages.

- isolement du virus et son identification à partir de prélèvements ganglionnaires ou de sang inoculés à des bovins à hyper-sensibilité connue : bétail des races Jersey ou Guernesey, bétail noir japonais, bétail N'Dama. Outre les difficultés de se procurer en tous lieux ces types de bétail, nous avons indiqué les limites de cetłe épreuve, et it reste qu'elle ne peut être pratiquée qu'en zone protégée contre le virus.

- isolement du virus en cultures cellulaires de rein d'embryon de veau, à partir d'un prélèvement de ganglion ou du sang circulant. Epreuve in vitro, de sensibilité certes moins grande que la précédente, mais tout aussi valable si l'on reste sur le plan qualitat ff et si l'on ne fait pas intervenir le titrage du virus à partir des produits pathologiques. A elle va notre préférence, car réalisable maintenant à l'échelon de toute nation et ne faisant appel qu'à des manipulations in vitro; l'identification du virus fait appel à un échantillon de sérum antipestique que tout laboratoire national se doit de posséder. Son utilisation est à recommander très vivement lorsqu'on suspecte une peste à virus atténué ; les lésions cytopathıques pathognomonıques sont du même ordre quelie que soit la virulence de la souche.

- démonstration de l'antigène pestique fixant le complément, laissantà l'expérimentateur le choix de techniques variées (fiche technique no 5) mais qui imposent également à un laboratoire national d'avoir un sérum hyperimmun de référence.

- démonstration de l'antigène pestique soluble par la réaction de précipitation-diffusion en gélose. Réaction in vitro la moins sensible de toutes, elle leur est supérieure par la sımplicité des manipulations 
qu'elle requiert, et mérite donc à ce titre d'être diffusée. Une hypothèque pèse néanmoins sur elle : son inaptitude à détecter, dans de nombreux cas, les souches hypovirulentes; si l'on voulait donc l'utiliser pour diagnostiquer de telles souches, c'est plus en sondage sur un troupeau malade qu'à ia faveur d'épreuves individuelles qu'il faudrait lui accorder du crédit.

- découverte des lésions histologiques, technique délicate, infidèle parce que celles-ci peuvent être supplantées par des lésions de nécrose. Un doute plane quant à la possibilité de reconnaître ainsi les pestes à formes atténuées.

2. En région infectée, le comportement du vétérinaire sera le même, attitude qui tranche avec les recommandations classiques. C'est l'expérience des pestes atténuées qui nous incite à recommander cette manière de faire car, malgré lèur sens clinique, les vétérinaires d'Afrique noire ne peuvent imposer en maintes circonstances le diagnostic de peste avec les seules données qu'ils recueillent. Pour eux, le recours au laboratoire, s'impose. Ils conformeront leur attitude ef leur choix auxindications exposées plus haut*.

Ainsi peut-on espérer, par la colfaboration intime du vétérinaire travaillant sur le terrain et de celui du laboratoire, se faire une opinion exacte sur toute maladie pestiforme et arriver, par la rapidité de l'intervention sanitaire ou médicale, à l'éradication de la peste du continent africain. L'œuvre, déjà commencée, doit s'amplifier dans les années à venir. Elle ne sera couronnée du succès qu'elle se doit d'avoir que si tous les problèmes qui existent sont un à un résolus; le diagnostic exact des foyers pestiques en est un.

* à l'exception près qu'ils devront soumettre deux échantillons de sérums (l'un prélevé à la phase aiguë, l'autre pendant la convalescence) pour bénéficier d'un séro-diagnostic valable. 


\section{FICHE TECHNIQUE No 1}

\section{FICHE DE RENSEIGNEMENTS}

Prélèvements pour recherche de Virologie, Sérologie, Histopathologie.

- No de référence:

— Nom, fonction et adresse de l'expéditeur :

- Date et lieu du prélèvement (distance d'un centre important, coordonnées géographiques...)

— Intervalle de temps entre le moment de la mort et celui du prélèvement:

- Espèce, sexe, âge de l'animal :

- Nature du prélèvement ( $s^{\prime} i l$ y en a plusieurs, détailler):

- Recherche demandée :

—Examen clinique du malade:

- Examen clinique du troupeau :

- Résultat de l'autopsie:

- Maladie suspectée :

- Effectif du troupeau :

- Nombre de malades dans le troupeau à la date du prélèvement (Malades + morts):

- Nombre de morts :

— Morbidité suivant l'âge:

- Mode et date d'expédition:

- Observations. 


\section{PRÉlĖVEMENTS A FAIRE EN VUE D'UN DIAGNOSTIC HISTOLOgIQUE DE PESTE BOVINE}

1. - Préparation des fixateurs.

- Fixateur de Duboscq-Brazil :

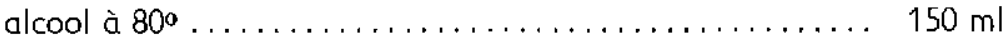

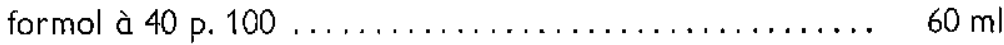

acide acétique .............................. $15 \mathrm{ml}$

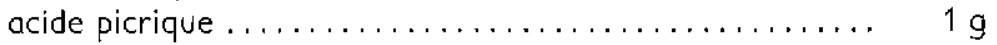

- Fixoteur de Flemming :

acide chromique d̀ 1 p. $100 \ldots \ldots \ldots \ldots \ldots \ldots \ldots, 15$ volumes

acide osmique d̀ 2 p. $100 \ldots \ldots \ldots \ldots \ldots \ldots \ldots \ldots \ldots .3$ volumes

acide acétique ........................... 1 volume

A défaut de pouvoir préparer l'u n ou l'autre de ces fixateurs, se servir d'eau formolée à 12 p. 100.

2. - Répartır le fixateur dans des flacons propres, d'assez grande ouverture, à fermeture bien étanche. Le volume de fixateur doit être d'au moins 10 fois celui du prélèvement.

3. - Prélever sur le cadavre (soit un animal abattu, soit un animal mort naturellement, à condition que les prélèvements ne soient pas faits plus de 6 heures après la mort) ;

— un fragment d'épithélium gingival, buccal, lingual, nasal, vulvaire ou du fourreau ;

- un fragment d'amygdale :

- des fragments de ganglions lymphatiques, avec une préférence pour ceux de la tête ; des fragments des plaques de Payer:

- un fragment de foie:

- un fragment de cerveau.

Les prélèvements auront $1 / 2 \mathrm{~cm}$ d'épaisseur, $2-3 \mathrm{~cm}$ de longueur, $1-2 \mathrm{~cm}$ de largeur. Les immerger totalement dans le fixateur. Ne pas mettre dans le flacon d'abord le prélèvement puis le fixateur, car le prélèvement adhérerait alors à la paroi et le fixateur ne pourrait pénétrer sur toutes les faces.

Chacun de ces prélèvements sera placé dans un flacon indépendant. Fermer hermétiquement. Etiqueter chaque flacon.

4. Remplir une fiche de renseignements (fiche technique no 1), en double exemplaire. L'une accompagnera les prélèvements.

5. Emballer dans un emballage résistant à l'écrasement et au choc. Remplir l'emballage d'une matière absorbante (fibre de bois, sciure, son, coton...).

6 Envoyer dans les meilleurs délais et par les moyens les plus rapides au laboratoire spécialisé. 
FICHE TECHNIQUE No 3

\section{MÉTHOdOLOGIE DES PRÉLĖVEMENTS POUR DIAGNOSTIC DE LA PESTE BOVINe PAR CULTURe CELluLAIRE}

I. Préparation de la solution de versène.

Le versène rendra le sang incoagulable; il est supérieur à l'héparine. Ne pas employer de citrate de sodium.

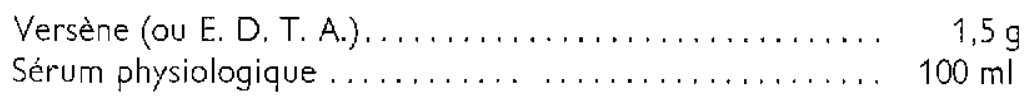

Répartir par $5 \mathrm{ml}$ en flacons de 20 ec préalablement stérilısés au four. Boucher au coton. Autoclaver 30 minutes à $120 \circ \mathrm{C}$ ( $2 \mathrm{~kg}$ de pression); autorlaver en même temps des bouchons de caoutchouc pour fermer les flacons. Après refroidissement, boucher les flacons avec les bouchons.

Si l'on ne dispose pas d'autoclave, mettre au bain-marie bouillant pendant une heure, et répéter l'opération 3 jours de suite en conservant le liquide à température ordinaire dans l'intervalle des opérations.

La solution de versène stérilisée peut être conservée bouchée à température ordinaire.

2. Prélèvement. On prélève

- soit un ganglion lymphatique sur un cadavre,

- soit du sang sur versène, à partir d'un animal vivant.

Matériel : Couteau à autopsie, pinces d̀ dents de souris, ciseaux, aiguilles 7-14/10, coton, alcool, teinture d'iode, sparadrap. Crayon à bille. Récipient hermétique stérilisé.

- sur le cadavre. Autant que possible, cadavre d'un animal fraîchement abattu, ou mort depuis peu de temps.

Prélever un ganglıon de la tête avec toutes les précautions désirables de stérilité : autopsie par plans successifs, préhension du ganglion avec les pinces sans y toucher autrement. Placer dans un récipient stérilisé ou d̀ défauf bouilli et pouvant fermer hermétiquement. Etiqueter et congeler sı possible. Envoyer sous glace au laboratoire avec une fiche de renseignements.

- sur l'animal vivant. Couper les poils sur la gouttière jugutaire. Désinfecter à la teinture d'iode (ou tout autre antiseptique puissant). Se passer les mains à l'alcool. Piquer la veine avec l'aiguille en s'efforçant de n'en pas tenir f'embout. Recueillir le sang dans un flacon de versène (1 partie de versène, 2 de sang). Boucher. Capsuler avec du sparadrap. Etiqueter. Mettre sous froid sans congeler. Expédier sous froid au laboratoire. 


\section{FICHE TECHNIQUE No 4}

\section{LA SÉRO-NEUTRALISATION}

\section{1. - Dans l'identification du virus bovipestique}

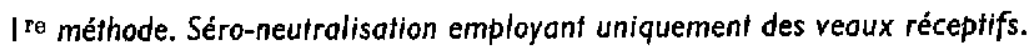

- Principe : Un sérum antipestique hyperimmun contre la peste bovine est mis en contact avec le virus suspect; le mélange virus-sérum est inoculé à des veaux sensibles. Sı le virus est celui de la peste bovine, il sera détruit par l'action neutralisante du sérum et les animaux r'extérioriseront aucun symptôme, tandis que d'autres veaux inoculés avec le même virus mélangé cette fois avec du sérum de bovin normal, contracteront la peste.

- Sérum : Dans une telle technique la qualıté du sérum neutralisant utilisé est essentieile. On utilisera le sérum d'un animal convalescent de peste bovine ou encore celui d'un animal vacciné pus hyperimmunisé par quatre inoculations sous-cutanées hebdomadaires de fortes doses de virus (broyat de rates et de ganglions). FOURNIER et HUARD (1959) obtiendraient un sérum antipestique de titre convenable en faisant des injections répétées de virus bovipestique lapinisé à des bovins à partır de pulpe de ganglions mésentériques de lapins infectés.

Ce sérum devraił être titré mais le titrage, qui consisterait à déterminer par séro-neutralisation chez le bouf le nombre de doses infectantes 50 p. 100 de virus bovipestıque que neutralise une quantité détermınée de sérum, s'avère trop onéreux.

Dans cette technique on admettra qu'un sérum antipestique neutralise 1.000 à $10.000 \mathrm{DI}_{50}$ par millilitre et que la rate de bovin infecté contient $10^{4}$ à $10^{5}$ doses infectantes par gramme.

Le jour de la récolte, on coupe les poils à l'emplacement choisı sur la jugulaire et on désinfecte avec un tampon de coton imbibé d'alcool rodé.

Le sang est récolté après pose d'un garrot à la base de l'encolure, à l'aide d'une aiguille de fort diamètre montée sur une seringue stérile de $20 \mathrm{cc}$. Il est rejeté dans un tube à essai stérile bouché au coton et marqué au numéro de l'animal.

Les tubes sont laissés debout à température ambiante pendant quatre heures. Puis le cailloł est décollé des parois du tube le plus aseptiquement possible avec une mince tige métallique flambée. Le sérum exude. Les tubes sont encore laıssés quatre heures à température ambiante puis vingt heures au réfrıgérateur. En partant de $20 \mathrm{ml}$ de sang on doit obtenir $10 \mathrm{ml}$ de sérum. Le sérum est recueilli dans des flacons de type pénicilline stériles. Des antibiotiques, pénıcilline et streptomycine, sont ajoutés au sérum à raison de $1.000 \mathrm{U}$. I. de pénicilline et $1 \mathrm{mg}$ de streptomycine par $\mathrm{ml}$.

- Préparation du matériel suspect: Matériel : ciseaux, mortıer, pilon et sable ou broyeur de verre ou mixer, glace, centrifugeuse, pots à centrifuger.

On utilise la rate ou les ganglions lymphatiques, ces derniers ayant pu être prélevés par biopsie sur un malade.

Les tissus prélevés doivent être gardés dans de la glace jusqu'à leur utilisation.

Des suspensions à 1 pour 10 et 1 pour 100 (poids pour volume) sont préparées dans une solution salıne isotonique ou en bouillon, par hachage avec des ciseaux et broyage avec du sable stérile (le broyeur de Ten Brock ou le mixer peuvent aussi être utilisés à condition d'éviter un échauffement 
excessif). Le surnageant, après centrifugation légère ou même simple décantation, constitue l'ınoculum. Des antibiotiques peuvent être ajoutés aux mêmes taux que précédemment.

Les préparations doivent être conservées au froid en attendant leur utilisation.

- Technique de f'épreuve. Nous avons déjà indiqué (cf : Diagnostic virologique) que le succès de cette technique était conditionné par la susceptibilité des veaux ef les facilités d'isolement des anımaux inoculés : les deux groupes ne doivent pas être en contact l'un avec l'autre, et tout sera mis en cuvre pour empêcher la transmission dú contage.

A chaque volume des suspensions de matériel suspect, on ajoute un volume égal de sérum préparé contre la peste bovine préalablement chauffé à $56^{\circ} \mathrm{C}$ pendant 30 minutes. Des mélanges analogues de matériel suspect et de sérum normal de bovin réceptif sont également préparés. Tous ces mélanges sont placés au bain-marie à $37^{\circ} \mathrm{C}$ pendant 30 à 60 minutes, puis ils sont inoculés chacun à deux bovins différents à rasson de $2 \mathrm{ml}$ par voie sous-cutanée.

Le titre du virus (si virus de la peste Il y a) contenu dans le matériel suspect baisse de $1 \mathrm{log}$. au cours de la phase de contact à $37^{\circ} \mathrm{C}$. En conséquence, $2 \mathrm{ml}$ de mélange contenant au départ $10^{3}$ à $10^{4} \mathrm{DI}_{50}$ pour la dilution de rate à $1 / 10$ et $10^{2}$ à $\left.10^{3} \mathrm{D}\right|_{50}$ pour la dilution de $1 / 100$, renferment respectivement $10^{2}$ à $10^{3}$ et $10 \mathrm{a} 10^{2} \mathrm{DI}_{50}$ après le séjour au bain-marie. Le sérum antipestique neutralisant 1.000 à $10.000 \mathrm{DI}_{50}$ de virus par $\mathrm{ml}$, neutralise donc le virus contenu dans les mélanges inoculés.

De cette façon, si le virus de la peste bovine existe dans les prélèvements de rate, les animaux inoculés avec le mélange virus-sérum de bovin réceptif extérıoriseront une peste tandis que les animaux inoculés avec les mélanges virus-sérum immun resteront indemnes.

\section{$2^{\mathrm{e}}$ méthode : Neutralisation in vivo sur veaux immuns.}

Dans cette méthode, le matériel suspect n'est plus mélangé à un sérum de bovin préparé contre la peste bovine eł à un sérum de bovin réceptif avant d'être inoculé à des bovins réceptifs, mais il est Inoculé tel quel à deux lots d'animaux: un lot de bovins rendus immuns par vaccination avec un virus vaccin et un lot de bovins réceptifs,

C'est en quelque sorte, une séro-neutralisatıon différée, les anticorps neutralisants existant dans le sérum même des animaux immuns mais n'existant pas dans celui des bovins réceptifs.

- Veaux. Cinq bovins au moins sont nécessaires. Ils doivent provenir d'une zone indemne de peste bovine et doivent être garantis non vaccinés contre cette maladie. A l'arrivée au laboratoire, ils sont saignés. Si on en a les facilités, on constatera l'absence d'anticorps neutralisants dans leur sérum par séro-neutralisation (voir plus bas: II).

Deux des animaux sont vaccinés avec un virus-vaccin (capripestique ou lapinisé). Normalement ils font une réaction légère mais nette consistant en une montée de température et l'établissement d'une diarrhée pendant un à deux jours. Ces animaux peuvent être considérés comme immuns deux à trois semaines après la vaccination.

- Matériel suspect. Mêmes précautions à prendre et même traitement que pour la première méthode ; une dilution (1/10, poids pour volume) est utilisée.

On peut également utitiser le sang citraté ou versené (voir fiche technique no 3 ) comme matériei suspect ; il devra être conservé sous glace, mais ne pas être congelé.

- Technique de l'épreuve. Les deux animaux immuns ef deux des réceptifs reçoivent par voie souscutanée $10 \mathrm{ml}$ de la suspension tissulaire à 10 pour 100. Les bovins sont examinés journellement pendant deux semaines. La température est prise tous les matins. Si le virus pestique est présent dans l'inoculum, les animaux réceptifs, mais non les immuns, réagissent en 1 à 11 jours. On recherchera comme précédemment les lésions anatomopathologiques sur les animaux morts.

Les non-réagissants et les survivants sont éprouvés 2 à 3 semaines plus tard par inoculation d'un virus bovipestique virulent ou un virus-vaccin caprinisé, en même temps que le $5^{e}$ animal restant. C'est le moyen de faire la part d'un virus bovipestique à virulence amoindrie qui aurait pu être présent dans le prélèvement. 


\section{Dans la recherche des anticorps neutralisants}

Le diagnostic de peste bovine peut être précısé par la mise en évidence dans le sérum des animaux atteints de la formation d'anticorps spécifiques, antı-peste bovine. Cette mise en évidence nécessite l'examen simultané de deux prélèvements de sérum pour chaque animal. Un sérum est prélevé avant contact ou durant la phase aigue de la maladie, l'autre est récolté troıs semaines après le débuł des signes cliniques. Etant donné que l'on recherche une montée du taux des anticorps neutralisants, l'examen d'un sérum unique n'apporte aucun renseıgnement démonstratif, à moıns qu'il ne vise à démontrer l'absence d'anticorps ou que l'on opère dans une région primitivement vierge d'infection pestique.

Le principe de la méthode est simple : le sérum avant contact, ou a la période aigue, et le sérum à la période de convalescence, sonł mélangés chacun à des dilutions de virus. Les différents mélanges sont inoculés à des animaux sensibles.

La montée du taux des anticorps neutralisants est confirmée si le titre du virus qui détermine I'apparition des symptômes ou lésions caractéristiques en présence de sérum de convalescent esł inférieur (ou neutralise totalement) au titre du virus qui détermine l'apparition des mêmes symptômes ou lésions en présence de sérum prélevé avant contact ou en phase aıguë.

Plusieurs méthodes ont été proposées utilisant des virus pestiques modifiés : séro-neutralisation du virus bovipestique caprinisé sur bœuf; séromeutralisation du virus bovipestique lapinisé sur lapin ; séro-neutralısatıon du virus bovipestique avianisé sur œuf; séro-neutralısatıon du virus bovipestique adapté à la culture cellulaire sur cultures de tissus.

Considérons successivement ces différentes méthodes.

\section{Virus caprinisé sur bovin.}

- Sérums. La technique d'obtention des sérums est celle décrite précédemment. Un prélèvement de $20 \mathrm{ml}$ de sang est largement suffisant (voir fiche technique no 7). Le sérum avant contact ou à la phase aigue et celui de la période de convalescence sont inactivés pendant 30 minutes à $56^{\circ} \mathrm{C}$, puis refroidis avant utilisation.

Dans le cas où la quantité de sérum obtenu seraıt faible, une dilution au 1/10 en sérum physiologique peut être réalisée.

- Virus. Le virus bovipestique caprinisé est dılué au 1/10 (poids de poudre sèche par volume de diluant) dans une solution isotonıque glacée, puis les dilutions $1 / 100,1 / 1.000,1 / 10.000,1 / 100.000$ sont réalisées.

- Technique. Un mınimum de vingt bovins reconnus sensıbles à la peste bovine est nécessaıre. $5 \mathrm{ml}$ de sérum prélevé à la phase aiguë sont mélangés à un volume égal de chaque dilution du virus.

De la même façon $5 \mathrm{ml}$ de sérum prélevé à la périade de convalescence sonł mélangés à un volume égal de chaque dilution de virus. Les tubes sont marqués, puis les mélanges sont agités et laissés une nuit au réfrigérateur. Le lendemain matin, $2 \mathrm{~m}$ t de chacun des mélanges sont injectés par voie sous-cutanée à deux bovins, en changeant d'algulle ef de seringue pour chaque mélange.

On prend chaque matın la température des animaux inoculés, en prenant soin de désinfecter les thermomètres oussıtôt après chaque prise de température.

L'existence de virus non neutralısé dans les mélanges se traduit dans les huit jours par une montée de la température suivie par l'apparition de légers signes cliniques. La spécificité de la réponse est confirmée en éprouvant les bovins deux semaines plus tard par l'inoculation du virus bovipestique virulent ou par réinoculation avec du virus caprinisé.

Le dıagnostic de peste est confirmé si le sérum prélevé à la convalescence a fait baisser d'au moins 100 fois (2 dilutions) le titre du virus par rapport à celui du mélange virus-sérum de la phase aigue. 


\section{Virus lapinisé sur lapin.}

a) Technique de SCOTT ef BROWN

- Sérums. Mêmes précautions pour le prélèvement que précédemment. Les sérums sont inactivés à $56^{\circ} \mathrm{C}$ pendant 30 minutes, puis dilués au $1 / 5$ en sérum physiologique. Les dilutions sont poussées à 1/50... 1/5.000 pour les sérums prélevés pendant la convalescence.

- Lapins. Les différentes races de lapins européens (Oryctologus cuniculus) peuvent être utilisées. Chaque individu devant être âgé d'au moins 4 mois et peser 1,5 à $2 \mathrm{~kg}$.

- Virus. On utilise le virus lapinisé Nakamura III. On se serł d'un stock de virus conservé Jyophilisé à $-20^{\circ} \mathrm{C}$; ce peut très bien être le vaccin courant.

Détermination du titre : La séro-neutralisation étant faite en présence de 20-200 DI $\mathbf{5 0}$ lapın, it est nécessaire de connaître le titre du stock de virus. On réalise donc un titrage préalable du stock: on prélève 2 flacons qui sonł réhydratés avec de l'eau distillée dans leur volume prımitif, puis on réalise en sérum physıologique glacé des dilutions du 1/10 au 1/1,000.000. On inocule par voie intraveineuse cınq lapins par dilution. Cinq jours plus tard, on sacrifie les lapins, et on note les lésions pathognomoniques à l'autopsie. On calcule le titre infectant ( $\left.D I_{\mathbf{5 0}}\right) 50$ p. 100 par la méthode de REED et $\mathrm{MUENCH}$.

- Technique. On dilue le virus-stock de façon à avoir une dilution contenant $20-200 \mathrm{DI} / \mathrm{ml} / \mathrm{m}$.

A chaque volume de chaque dilution $(1 / 5,1 / 50,1 / 500,1 / 5.000)$ de sérum de la phase convalescente, on ajoute un volume de suspension virulente. On opère de même avec le sérum de la phase aiguë, sur les dilutions $1 / 1$ et $1 / 5$. Les tubes de mélanges sont étiquetés, et mis à incuber, soit une heure à $37^{\circ}$, soit une nuit au réfrigérateur. Un échantillon de la dilution de virus subit le même traitement.

On inocule, par voie intraveineuse, troıs à cinq lapins par mélange, en changeant de seringue et d'aiguille pour chaque mélange. Les lapins sont sacrifiés cinq jours pius tard, autopsiés pour la reconnaissance des lésions pathognomoniques.

L'apparition d'anticorps bovipestıques est indiquée par l'inaptitude du sérum de la phase aıguë à neutralıser le virus (présence de lésions pathognomoniques) et l'aptitude des plus faibles dilutions du sérum de la période de convalescence à empêcher l'infection (aucune lésion).

\section{b) Technıque de HUARD, ANDRE et FOURNIER (1959)}

- Sérums. Le sérum avant contact ou de la période aigue, et le sérum de la période de convalescence sont également inactıvés 30 minutes à $56^{\circ} \mathrm{C}$. A l'inverse de la technique de SCOTT, les sérums ne sont pas dilués.

- Virus. Provient du broyat des ganglions mésentériques, fraîchement prélevés sur des lapins infectés avec le virus bovipestique lapinisé. Ce broyat est mis en suspension dans une solution de HANKS avec 10 p. 100 de sérum de cheval de manière à obtenir une dilution $1 / 5$ (poids/volume) puis des dilutions décimales en sérum physiologique + sérum de cheval sonł réalisées jusqu'au 1/5.000.000.

- Technique. Comme pour la technique de SCOTT et BROWN, les différentes races de lapins européens pesant $1,5 \mathrm{~kg}$ sont utilisables; deux ml de sérum de la période aiguë sont mélangés à un volume égal de chaque dilution du virus, et simultanément deux $\mathrm{m}$ l de sérum de la période de convalescence sont aussi mélangés d̀ des volumes égaux des dilutions du virus. Les mélanges sont agités puis portés d̀ $37^{\circ} \mathrm{C}$ pendant une heure. Un ml de chacun d'eux est injecté par voie intraveineuse à deux lapins. Les températures rectales des animaux sont prises tous les jours. Les lapins sont sacrifiés anq jours après l'inoculation.

On conclut à la présence d'anticorps antipestiques dans le sérum de la convalescence, si ce sérum a réduit d'au moins 100 fois $(2 \mathrm{log}$.) le titre du virus par rapport à celui mélangé au sérum de la phase aiguë. 


\section{Virus bavipestique adopté ò la culfure cellulaire sur culfures cellulaires.}

- Sérums. Le sérum avant contact ou à la période aıguë de la maladie et celui de la période de convalescence sont inactivés à $56^{\circ} \mathrm{C}$ pendant trente minutes. Pour un résultat qualitatif, il est inutile de les diluer.

— Vırus. La souche de virus adaptée à la culture cellularre est diluée d'après les résultats de titrages précédents de façon à contenir 102,2 $D C_{50}$ par mi. Pour comparer utilement les résultats entre les différents instituts, il est recommandé d'utiliser la souche RPKOBK de l'E. A. V. R. O., Muguga, Kenya.

- Technique. Les cultures de cellules sontréalisées à partir de cellules de reins d'embryons de veau.

Des volumes égaux de virus et de sérum de la période aiguë sont mélangés. De la même façon, on mélange aussı des volumes égaux de virus ef de sérum de la période de convalescence. Les mélanges sont laissés 1 heure à $37^{\circ} \mathrm{C}$ puls chacun d'eux est ajouté à une suspension de cellules de rein de veau (une partie de mélange pour 9 parties de suspension cellulaire dans son milieu de croissance), puis on répartit $1 \mathrm{ml}$ de chaque mélange dans des tubes pyrex de $14 \mathrm{~mm}$, bouchés au caoutchouc. Les cellules forment des tapis monocellulaires sur les parois des tubes qui les contiennent. Dès que le tapis est formé, on met les tubes sur un « roller-tube ». Les cultures de cellules sont examinées chaque jour pendant 12 jours après renouvellement du milıeu lorsque ce dernier devient trop acide.

La présence d'anticorps bovipestiques est indiquée par l'inaptitude du virus adapté aux cultures cellulaires de provoquer des modifications cytopathiques en présence de sérum de la période de convalescence, alors qu'en présence de sérum de la période aiguè le virus détruit la couche "celluJaire.

\section{Virus bovipestique avianisé sur embryon de poulet.}

— Sérums. Les deux sérums sont toujours inactivés 30 minutes à $56^{\circ} \mathrm{C}$.

- Virus. C'est la variante Muguga de la souche japonaise de virus bovipestique avianisé qui est utilisée car elle tue 90 pour 100 des embryons de poulet inoculés.

- Technique. Les œufs sont incubés cinq jours à $39^{\circ}$ puis ils sont mirés de façon à éliminer les œufs non fécondés. Des volumes égaux de chaque sérum ef de virus sont mélangés et les mélanges sont laissés une nuit au réfrigérateur. Le lendemain $0,5 \mathrm{ml}$ de chaque mélange sont injectés dans le vitellus de vingt-cinq œufs. Cinquante ceufs seront donc nécessaires pour étudier une paire de sérum. Les œufs inoculés sont replacés dans l'incubateur à $35^{\circ} \mathrm{C}$. Ils sont suivis tous les jours pendant dix jours et les morts sont notés.

L'existence des anticorps est indiquée par le faible taux de mortalıté chez les œufs inoculés avec le virus mélangé au sérum de la période de convalescence alors que le taux de mortalité chez les œufs inoculés avec le virus mélangé au sérum de la période aıguë est élevé.

Une différence de 60 pour 100 dans les deux taux de mortalité est significative.

Remarque: C'est pour être complet que nous mentionnons cette dernıère méthode. Si elle a donné de bons résultats en Afrıque orientale et en Extrême-Orient, il a été difficile de la mettre en ceuvre en Afrique centrale et occidentale. 
FICHE TECHNIQUE NO 5

\section{LA DÉVIATION DU COMPLÉMENT}

\section{A. - Mise en évidence de l'antigène}

\section{Technique de Nokamura}

(voir : Manuel technique et d'application : la réaction de déviation du complément en matière de peste bovine, O. I. E., 1959).

\section{Réactifs}

Les réactifs sont mesurés au moyen de pipettes de $1 \mathrm{ml}$, dans des tubes de Kahn d'un diamètre intérieur de $10 \mathrm{~mm}$ ef d'une hauteur de $90 \mathrm{~mm}$, que l'on remplit jusqu'à un volume total de $5 \mathrm{ml}$. La solution utilisée pour diluer les réactifs ef les mélanger est une solution à 0,85 p. 100 de $\mathrm{NaCl}$ dont le $\mathrm{pH}$ est ajusté à 7,2-7,4 au moyen d'un tampon phosphaté $\mathrm{M} / 150$.

\section{Suspension d'hématies.}

Du sang de chèvre frais, défibriné sur billes de verre, est utilisé pour obtenir une suspension d'hématies. Les hématıes sont lavées par centrifugation à plusieurs reprises avec une solution salée d 0,85 p. 100 jusqu'à ce que le surnageant devienne limpide; le sédiment est alors pipetté dans le volume de solution salée tamponnée nécessaire pour obtenir une suspension à 2,2 p. 100 en volume.

\section{Complément.}

Il est préférable d'utiliser le complément lyophilisé ; sa conservation est satisfaisante à basse température. C'est celui dont l'emploi est le plus commode dans les pays tropicaux et le moins sujet à des variations de tıtre.

\section{Sérum hémolytique.}

Du sérum de lapins immunısés par des injections répétées d'hématies lavées de chèvres, est utilisé comme hémolysine. Elle est titrée en présence d'hématies de chèvres à 2,2 p. 100 ef en présence de complément au 1/15. Les mélanges sont placés 30 minutes à $38^{\circ} \mathrm{C}$. La plus forte dilution de sérum de lapin provoquant une lyse complète représente l'unité hémolytique.

\section{Hématies sensibilisées.}

La suspension d'hématies à 2,2 p. 100 est sensibilısée avec quatre unités d'hémolysine ; la quantité réelle d'hémolysine à ajouter doit être calculée de façon qu'elle ne puisse pas excéder 5 p. 100 du volume de la suspension d'hématies.

\section{Sérums.}

Le sérum de bovin hyperimmun ou le sérum de lapin convalescent peuvent être utilisés.

- Le sérum de bovin est abtenu par saignée de taureaux très réceptifs, qui ont d'abord reçu une immunité de base contre la peste bovine par vaccination au moyen d'un virus vivant ou tué, puis des injections répétées d'un virus très virulent à intervalle d'une semaine. Ces injections sont des suspensions frâches à 10 p. 100 de ganglions lymphatiques de bovins infectés. On inocule d'abord $50 \mathrm{ml}$ et en augmentant de $50 \mathrm{ml}$ chaque semaine on arrive à $500 \mathrm{ml}$. La première saignée est effectuée 14 jours après la dernière inoculation de virus. On le conserve congelé en attendant son titrage et son utilisation. Ce sérum est utılisé sans chauffage préalable. II est titré en présence d'un antigène standard. 
- Le sérum de lapin convalescent est récolté sur les lapins survivants du quinzième au vingtıème jour après inoculation intraveineuse à ces anımaux d'un virus bovipestique lapınisé ou lapinısé-avianisé. Ce sérum doit être chauffé au baın-marie à $60-62^{\circ} \mathrm{C}$ pendant 30 mınutes avant son empioi.

- Des sérums de bovins et de lapins négatifs sont prévus à titre de témoins.

Antigène. Les ganglions lymphatiques frais décapsulés sont broyés, mis en suspension dans 9 volumes de solution physiologique tamponnée et conservés, congelés durant une nuit dans un congélateur à $-20 \circ$ C. Après décongélation, la suspension est placée au bain-marie bouillant pendant 30 à 60 minutes. Cette suspension est de nouveau remise au congélateur à basse température durant la nuit suivante, puis centrifugée. Le liquide surnageant est l'antigène.

Un antigène négatif est préparé de la même façon à partir des ganglıons d'un bovin sain. Technique.

\section{- Titrage du complément.}

On détermine d'abord la dose minimale hémolytique de complément en présence du sérum antibovipestique de référence car certains sérums ont un pouvoir anticomplémentaire.

Dans une première série de 6 tubes qui doivent permettre de détermıner la dose minimale hémolytique en l'absence de sérum, le complément est réparti en série par volume de 0,3,0,25 et 0,2 $\mathrm{ml}$ des dilutions à $1 / 80$ et à $1 / 40$ (tableau 2). Dans une seconde série de 9 tubes qui doivent permettre de déterminer la dose minimale hémolytique du complément après contact avec le sérum antıbovipestique, $0,1 \mathrm{ml}$ de dilution à $1 / 10$ du sérum et des volumes de complément $0,3,0,25,0,2 \mathrm{ml}$ des dilutions à $1 / 20,1 / 40$ et $1 / 80$ sont successivement répartis. Les tubes sont alors complétés à $0,4 \mathrm{ml}$ avec du sérum physiologique. Après une période de fixation de 4 heures à $1-5{ }^{\circ} \mathrm{C}$ ou de 2 heures à $20-25{ }^{\circ} \mathrm{C}, 0,1 \mathrm{ml}$ d'une suspension de globules rouges sensıbilisés sont ajoutés à chacun des tubes. Ceux-ci sont alors placés au bain-marie à $38^{\circ}$ pendant 30 minutes.

\section{TABLEAU 2}

Détermınation de la dose minimale hémolytique de complément (technique de Nakamura)

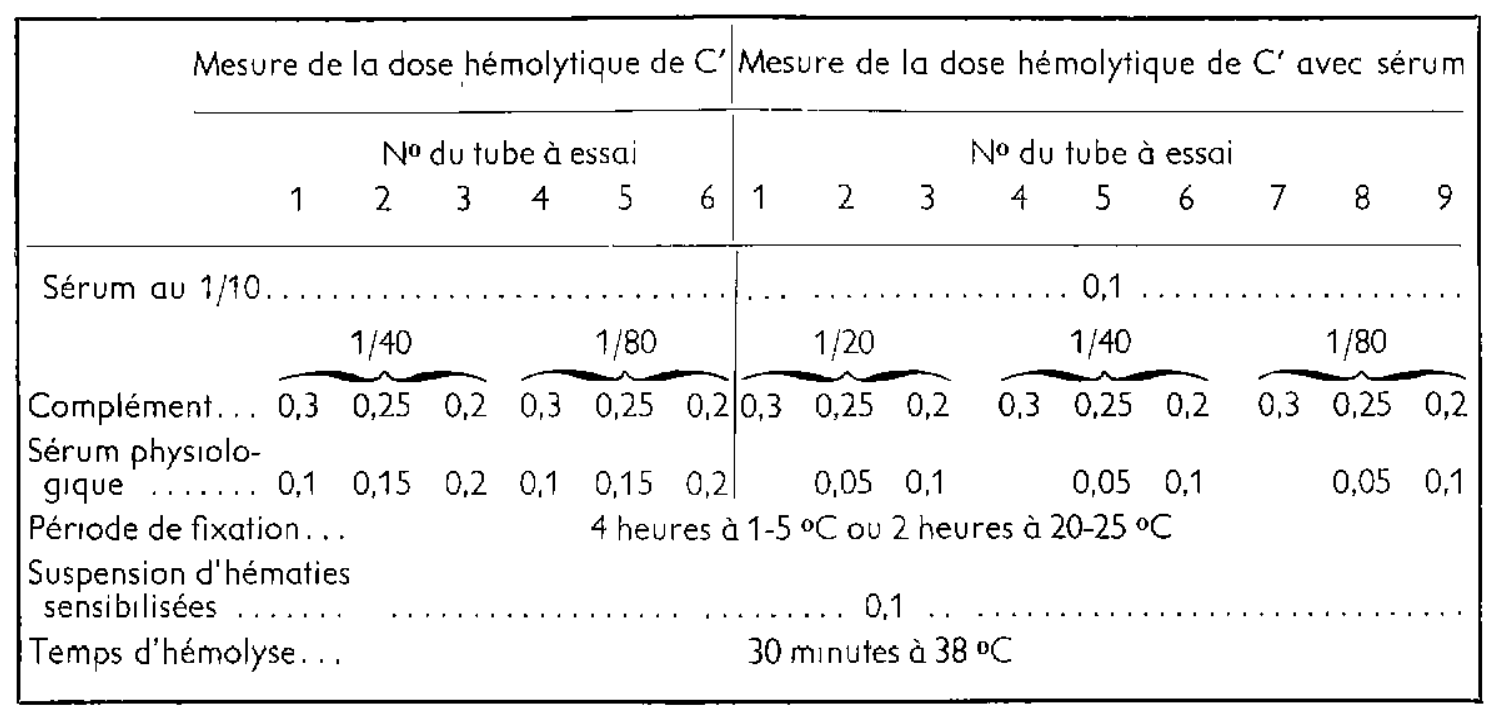

La dose de complément à utiliser est calculée sur la base de la valeur de la dose mınimale hémolytique du complément en présence de sérum antibovipestique : elle contient, dans un volume de 0,1 ml, 1,2 de cette dose minimale hémolytıque. 


\section{- Epreuve finale.}

Neuf tubes sont nécessaires pour la réaction elle-même et quatre pour les témoins.

Dans les neufs tubes l'antigène, ie sérum et le complément sont mélangés ensemble. L'antigène est réparti dans les volumes de $0,2,0,1$ et $0,05 \mathrm{ml}$ en trois séries, correspondant aux dilutions $1 / 1,1 / 8$ et $1 / 64$. Le complément est ajouté à la dilution précédemment calculée sous le volume de $0,1 \mathrm{ml}$ et le sérum à la dilution $1 / 10$ sous le volume de $0,1 \mathrm{ml}$, le volume total de chaque tube étant ramené à $0,4 \mathrm{ml}$ avec de l'eau physiologique.

Les tubes témoins comprennent 3 tubes sans sérum (antigène aux trois dilutions sous volume de $0,2 \mathrm{~m} /$ complément et sérum physiologique) et un tube sans antigène mais avec du sérum, complément et eau physiologique. La fixation du complément s'effectue soit à $1-5^{\circ} \mathrm{C}$ pendant 4 heures, soit à $20-$ $25^{\circ} \mathrm{C}$ pendant 2 heures. Le couple hémolytique $(0,1 \mathrm{ml}$ de giobules rouges sensibilisés) est alors ajouté et la lecture s'effectue après contact pendant 30 minutes au bain-marie à $38^{\circ} \mathrm{C}$.

TABLEAU 3

Epreuve finale

\begin{tabular}{|c|c|c|c|c|c|c|c|c|c|c|c|c|c|}
\hline \multirow{2}{*}{ Réactifs } & \multicolumn{13}{|c|}{ Numéro des tubes à essai } \\
\hline & 1 & 2 & 3 & 4 & 5 & 6 & 7 & 8 & 9 & $\mathrm{Cl}$ & $\mathrm{C} 2$ & $\mathrm{C} 3$ & C4 \\
\hline & \multicolumn{3}{|c|}{$1 / 1$} & \multicolumn{3}{|c|}{$1 / 8$} & \multicolumn{3}{|c|}{$1 / 64$} & $1 / 1$ & \multicolumn{3}{|c|}{$1 / 81 / 64$} \\
\hline Antigène & 0,2 & 0,1 & 0,03 & 0,2 & 0,1 & 0,05 & 0,2 & 0,1 & 0,05 & 0,2 & 0,2 & 0,2 & \\
\hline sérum physiologique. & & 0,1 & 0,15 & & 0,1 & 0,15 & & 0,1 & 0,15 & 0,1 & 0,1 & 0,1 & \\
\hline$C^{\prime}(1$ à $2 \mathrm{DH})$ & \multicolumn{13}{|c|}{0,1} \\
\hline Sérum au $1 / 10 \ldots \ldots$ & \multicolumn{13}{|c|}{$\ldots \ldots \ldots \ldots \ldots \ldots, 0,1 \ldots \ldots \ldots \ldots \ldots \ldots \ldots \ldots \ldots \ldots \ldots \ldots, 1$} \\
\hline Période de fixation & \multicolumn{13}{|c|}{4 heures à $1-5^{\circ} \mathrm{C}$ ou 2 heures à $20-25^{\circ} \mathrm{C}$} \\
\hline Hématies sensibilisées & \multicolumn{13}{|c|}{$\ldots \ldots \ldots \ldots, 0,1 \ldots \ldots \ldots \ldots \ldots$} \\
\hline Temps d'hémolyse ... & \multicolumn{13}{|c|}{30 minutes ò $38^{\circ}$} \\
\hline Diagnostic & \multicolumn{13}{|c|}{ Exemples (les chiffres expriment les degrés d'hémolyse) } \\
\hline Positif ........... & 0 & 0 & 0 & 0 & 0 & 1,5 & 3 & 4 & 4 & 4 & 4 & 4 & 4 \\
\hline Positif . ...... & 3 & 2 & 1 & 0 & 0 & 0 & 1 & 3 & 4 & 4 & 4 & 4 & 4 \\
\hline Positif .......... & 2 & 1 & 0 & 1 & 2,5 & 3,5 & 4 & 4 & 4 & 4 & 4 & 4 & 4 \\
\hline Faiblement positif & 2 & 1 & 2 & 3 & 4 & 4 & 4 & 4 & 4 & 4 & 4 & 4 & 4 \\
\hline Douteux .............. & 4 & 4 & 3,5 & 3,5 & 4 & 4 & 4 & 4 & 4 & 4 & 4 & 4 & 4 \\
\hline Négatif ........ & 4 & 4 & 4 & 4 & 4 & 4 & 4 & 4 & 4 & 4 & 4 & 4 & 4 \\
\hline
\end{tabular}

Les résultats sont calculés d'après l'intensité de l'hémolyse estimée par rapport à une série de témoins standardisés. La réaction est fortement positive si l'hémolyse est tołalement inhibée dans trois tubes au moins; modérément positive pour un ou deux tubes; faiblement positive si l'hémolyse est partielle $(++$ ou +$)$ dans un ou plusieurs tubes; douteuse si l'hémolyse est partielle $( \pm)$ dans un ou plusieurs tubes, et négative si l'hémolyse est complète dans tous les tubes.

La présence de l'antigène peut être décelée par la méthode de fixation du complémentà partir du $2^{e}$ ou $3 \mathrm{e}$ jour de l'hyperthermie, le maximum du pouvoir antigénique se situant aux $3^{\mathrm{e}}$ et $4 \mathrm{e}$ jours. $\mathrm{Si}$ l'évolution de la maladie est très rapide, la mort de l'animal peut survenir avant l'apparition d'une réaction positive. 


\section{Technique de Boulonger}

\section{- Sérums de référence.}

D'après BOULANGER, des lapins sont inoculés avec $3 \mathrm{ml}$ d'une suspension à $1 / 25$ (poids/volume) en eau physiologique, de rate de lapin infecté avec la souche lapinisée Nakamura lil de virus bovipestique. Des saignées sont faites antérieurement à l'inoculation pour servir de contrôle. Quinze jours après l'inoculation, les lapins sont saignés et chaque sérum est éprouvé individuellement par la réaction de fixation du complément en utilisant comme antigène des extraits chimiques de rates de lapins infectés de virus lapinisé.

Les sérums qui après dilution au $1 / 20$ ou $1 / 40$ fixent 3 unités hémolytiques 50 p. 100 de complément, sonł mélangés et servent de sérum de référence. Ils sont conservés soit congelés soił lyophilisés.

En fait, la souche de virus bovipestique lapinisé Nakamura lli tuant en Afrique noire la plupart des lapins inoculés, ceux-ci sont d'abord immunisés par inoculations de sérum hyperimmun (voir fiche technique $n^{\circ} 6,2^{\mathrm{e}}$ temps) puis reçoivent le virus lapinisé le jour suivant par voie intraveineuse. Ils reçoivent ensuite tous les quatre jours des inoculations intrapéritonéales de $1 \mathrm{ml}, 2 \mathrm{ml}$ et $4 \mathrm{ml}$ de suspension à 30 p. 100 en equ physiologique de ganglions lymphatiques de lapins infectés avec la souche Nakamura III. Le sérum est récolté 9 jours après la dernière injection par ponction cardiaque.

Des sérums de lapins normaux non infectés sont utilisés comme sérums témoins.

Les sérums normaux et les sérums immuns sont inactivés à $56^{\circ} \mathrm{C}$ pendant 30 minutes juste avanf leur utilisation.

\section{- Antigène.}

La rate frâche du bovin est prélevée et la capsule enlevée soigneusement. On pèse $100 \mathrm{~g}$ de pulpe, qui sont broyés dans un mixer ou dans un mortier avec approximativement $500 \mathrm{ml}$ d'acétone refroldi.

Le mélange est agité pendant 20 minutes dans un réfrigérateur à $9{ }^{\circ} \mathrm{C}$; ensuite il est centrifugé à 2.000 tours/mn, pendant 30 minutes. Le sédiment est remis en suspension dans le même volume d'acétone refroidie que: précédemment, et les mêmes opérations sont recommencées. L'extraction à l'acétone est répétée encore une fois puis le sédiment est soumis à l'extraction avec un mélange d'acétone et d'éther anhydre et finalement deux fois avec de l'éther anhydre pur. Toutes les extractions sont faites en chambre réfrigérée.

Du chloroforme à la concentration de 1 p. 100 est ajouté pendant 24 heures à la dernière extraction pour inactiver le virus. Ensuite l'éther résiduel est évaporé sous vide pendant deux heures ou jusqu'à ce que le matériel splénıque prenne l'aspect d'une poudre sèche. Cette poudre esł́ mise en suspension dans $100 \mathrm{ml}$ d'eau physiologique et agitée durant une nuit à $9^{\circ} \mathrm{C}$. Elle est alors centrifugée pendant 15 minutes à 2.000 tours $/ \mathrm{mn}$. Le sédiment est rejeté. Le liquide surnageant est de nouveau centrifugé à 10.000 tours/mn pendant une heure. Le surnageant final constitue l'antigène suspect.

\section{- Complément.}

Etant donné sa plus grande stabilité et sa facilité de conservation, c'est le complément lyophilisé qui est utilisé.

\section{- Système hémolytique.}

Le sérum hémolytique provient de lapins adultes ayant reçu des injections (Intraveineuses ou intrapéritonéales) répétées de 7 à 10 jours d'intervalle de quantités croissantes de suspensions concentrées d'hématies de mouton lavées.

Ce sérum est titré vis-à-vis d'une suspension d'hématies de mouton à 2,5 p. 100 en présence d'un excès de complément. La plus forte dilution de sérum de lapin provoquant l'hémolyse complète des hématies représente l'unité hémolytique.

Dans la réaction finale, une suspension à 2,5 p. 100 d’hématies de mouton en solution physiologique tamponnée, est sensibilisée en ajoutant 5 unités hémolytiques de sérum hémolytique. 


\section{- Technique.}

La méthode utilisée pour tıtrer le complément est celle décrite dans «The standard methods of the Division of Laboratories and Research of the New York State Department of Health 》.

La dose hémolytique 50 p. 100 (DH 50) de complément est calculée en présence de la dilution à $1 / 5$ de sérum immun ou de sérum de lapin normal. La période de fixation est de une heure à $37^{\circ} \mathrm{C}$, suivie de 30 minutes à $37^{\circ} \mathrm{C}$ après addition des globules rouges de mouton sensibilisés.

Deux séries de dilutions d'antigène sont préparées sous le volume de $0,1 \mathrm{ml}$. Les dilutions sont en progression géométrique de raison 2 .

Le complément, dilué de façon à présenter trois doses hémolytiques 50 p. 100 sous un volume de $0,1 \mathrm{ml}$, est ajouté à chaque tube : $0,1 \mathrm{ml}$ de sérum immun de lapin inactivé par la chaleur dilué au $1 / 5$ est ajouté aux tubes de la $1 \mathbf{r e}$ série, tandis que $0,1 \mathrm{~m} /$ de sérum de lapin réceptif dilué au $1 / 5$ est ajouté aux tubes de la $2^{\mathrm{e}}$ série. La fixation se fait 18 heures à $+9^{\circ} \mathrm{C}$. Après ce temps, $0,2 \mathrm{ml}$ d'une suspension à 2,5 p. 100 d'hématies de moutons sont ajoutés à chaque tube. La lecture se fait après incubation de 30 minutes à $37^{\circ} \mathrm{C}$.

L'antigène bovipestique spécifique es† mis en évidence dans le prélèvement suspect par la constatation d'hématies intactes dans les tubes de la $1^{\text {re }}$ série contenant la plus faible dilution d'antıgène.

\section{Technique de Cowan}

\section{- Antigène.}

Les ganglions lymphatiques des viscères et de la carcasse des animaux suspects de peste bovine sont prélevés. La graisse ef la capsule sont éliminées et les ganglions sont coupés en fins morceaux aux ciseaux avant d'être broyés dans un mortier avec du sable ef un pilon. On obtient une pâte homogène quI, centrifugée pendant 10 minutes à 2.000 tours $/ \mathrm{mn}$, laisse exsuder un liquide que l'on recueille. Ce liquide est dilué au $1 / 4$ dans du tampon véronal (voir plus loin) et centrifugé pendant 1 heure à 2.000 tours/mn. Trois couches distınctes apparaissent après centrifugation : une couche supérieure blanche graisseuse, une couche moyenne assez trouble et un sédıment dans le fond. La couche moyenne est recueillie par siphonage à la pipette. Elle constitue l'antigène.

\section{- Anticorps.}

Dans la technique originale, le sérum hyperimmun antipestique est préparé en inoculant à des lapins par voie intraveineuse (veine marginale de l'oreille) la souche lapinisée-avianisée du virus bovipestique et en continuant par des inoculations répétées de gangłions de lapins infectés.

On peut avec avantage se servir de la méthode décrite dans la fiche technique $n^{\circ} 6,2^{e}$ temps, qui ne réclame pas d'inoculation préalable de virus lapinisé-avianisé.

Le sérum est inactivé 30 minutes à $56^{\circ} \mathrm{C}$ avant son usage.

\section{- Complément.}

Il est constitué par du sérum de cobayes adultes en bonne santé, saignés à blanc par ponction cardiaque. Le sérum est prélevé autour du caillot et centrifugé au froid. Le surnageant qui constitue le complément est conservé à - $40^{\circ} \mathrm{C}$ dans des tubes de $2 \mathrm{ml}$ bouchés. Ełant donné les difficultés d'avoir un bon complément de cette façon là dans les conditions climatiques de l'Afrique centrale, le complément qui est utilisé le plus généralement est du complément lyophilisé venant d'Europe.

\section{- Système hémolytique.}

Le sérum hémolytique est obtenu chez des lapins adultes qui ont reçu des injections intraveineuses trois fois par semaine de doses croissantes d'une suspension concentrée de stroma de globules rouges de moutons soigneusement lavés et bouillis. Douze doses sont administrées et cinq jours après la dernière injection les lapins sont saignés à blanc par ponction cardiaque. Les sérums sont récoltés et chauffés à $56^{\circ} \mathrm{C}$ pendant 30 minutes avant d'être stockés d̀ $-40^{\circ} \mathrm{C}$. La quantité optimale d'anticorps pour sensibiliser les hématies de mouton est ensuite déterminée. 
Une suspension à 5 p. 100 d'hématies de mouton lavées et préparées en tampon véronal est ajustée pour contenir $10^{9}$ cellules par $\mathrm{ml}$. Un volume égal d'une dilution appropriée de sérum de lapin anti-globules rouges de mouton est alors ajouté.

\section{- Technique.}

La dose hémolytique 50 p. 100 du complément est déterminée en présence du sérum de lapin hyperimmun. La dose de sérum de lapin hyperimmun à utiliser est déterminée par la plus haute concentration qui n'a pas de pouvoir anticomplémentaire mais qui donne cependant une bonne fixation avec un antigène positif connu. (Le sérum hyperimmun utilisé par Cowan est dilué au 1/50).

L'antigène qui avait été dilué au $1 / 4$ au cours de sa préparation, est encore dilué au $1 / 5$ de façon à obtenir une dilution finale au $1 / 20$.

Des dilutions $1 / 40,1 / 80,1 / 160,1 / 320,1 / 640$ et $1 / 1280$ sont alors réalisées en tampon véronal *.

Trois séries de tubes contenant chacune $0,2 \mathrm{ml}$ des différentes dilutions de l'aritigène sont préparées. La première série est celle de la réaction, la deuxième et la trosième servent de témoins. $0,2 \mathrm{ml}$ de sérum de lapin hyperimmun sont ajoutés aux tubes de la $2^{\mathrm{e}}$ sérıe et $0,35 \mathrm{ml}$ de tampon véronal aux tubes de la 3 e série.

$0,25 \mathrm{ml}$ de complément dilué de façon à contenir sous ce volume 5 doses hémolytiques 50 p. 100 sont ajoutés à chaque tube de la $1^{\text {re }}$ et de la $2^{\mathrm{e}}$ séries. Les tubes de la $3^{\mathrm{e}}$ série ne reçoivent que $0,1 \mathrm{ml}$ de la même dilution de complément, ce qui, en fait, représente deux doses hémolytiques 50 p. 100.

Les tubes sont laissés une nult au réfrigérateur, puis Ils sont réchauffés à $37^{\circ} \mathrm{C}$ pendant 15 minutes avant de recevoir chacun $0,1 \mathrm{ml}$ d'hématies de mouton sensibilisées. Ils sont alors mis au bain-marie à $37{ }^{\circ} \mathrm{C}$, pendant une heure, puis finalement placés au réfrigérateur. La lecture est faite une heure ou deux plus tard, après que les globules rouges non lysés se soient déposés.

TABLEAU 4

Déviation du complément, technique de Cowan

\begin{tabular}{|c|c|c|c|c|c|c|c|c|c|c|c|c|c|c|c|}
\hline \multirow[b]{3}{*}{ Antigène } & \multicolumn{5}{|c|}{ Tre série } & \multicolumn{5}{|c|}{$z^{*}$ série } & \multicolumn{5}{|c|}{ Ze série } \\
\hline & $1 / 40$ & 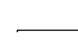 & - & $\longrightarrow 1$ & $1 / 1280$ & $1 / 40$ & & 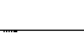 & $\longrightarrow 1$ & $1 / 1280$ & $1 / 40$ & 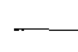 & - & $\rightarrow 1 /$ & 1280 \\
\hline & 0,2 & 0.2 & 0,2 & 0,2 & 0,2 & 0,2 & 0.2 & 0,2 & 0,2 & 0,2 & 0,2 & 0.2 & 0,2 & 0,2 & 0,2 \\
\hline Sérum $\quad \ldots \ldots \ldots \ldots$ & 0,2 & 0,2 & 0,2 & 0,2 & 0,2 & & & & & & & & & & \\
\hline Tampon véronal ........ & & & & & & 0.2 & 0,2 & 0,2 & 0,2 & 0,2 & 0,35 & 0,35 & 0,35 & 0,35 & 0,35 \\
\hline Complément ......... & 0,25 & 0,25 & 0,25 & 0,25 & 0,25 & 0,25 & 0,25 & 0,25 & 0,25 & 0,25 & 0,1 & 0,1 & 0,1 & 0,1 & 0,1 \\
\hline Période de fixation ..... & \multicolumn{15}{|c|}{18 heures à $4^{\circ} \mathrm{C}$, puis 15 minutes à $37^{\circ} \mathrm{C}$} \\
\hline Hématies sensibıl isées .. & \multicolumn{15}{|c|}{0,1} \\
\hline Période d'hémolyse .... & \multicolumn{15}{|c|}{1 heure à $37^{\circ} \mathrm{C}$, puis 2 heures d̀ $4^{\circ} \mathrm{C}$} \\
\hline
\end{tabular}

L'antigène bovipestique spécifique dans le prélèvement suspect est révélé par la présence d'hématies non hémolysées dans les tubes de la 1 re série, contenant les plus faibles dilutions d'antigène.

* Le tampon véronal ou solution de Mayer-Kraft est préférable à l'eau physiologıque pour les solutions dans les réactions de fixation du complément parce qu'il apporle les quantités optima les de Ca $\alpha^{L:}$ et $\mathrm{Mg}^{++}$pour l'activité du complément, au $\mathrm{pH}$ le plus favorabie.

Pour constituer la solution mère qui es conservée à 4 o C, il convient de fare dissoudre $5,75 \mathrm{~g}$ de véronal dans $500 \mathrm{ml}$ d'eau distillée en chauffant légèrement puis de compléter à $2.000 \mathrm{ml}$ en ajoutant $3.75 \mathrm{~g}$ de véronal sodique, $15 \mathrm{~g}$ de chlorure de sodium, $1,68 \mathrm{~g}$ de chlorure de magnésium ef $0,28 \mathrm{~g}$ de chlorure de calcium.

Cefte solution est autoclavée 20 minutes à $10^{\circ} \mathrm{C}$ avant d'être conservée à $\div-4^{\circ} \mathrm{C}$. Son $\mathrm{pH}$ dolt êlre de 7,2 .

Lors de son emploı, elle est diluée au $1 / 5$ en eau distillée. 


\section{Technique de Stone et Moulton}

\section{- Anticorps.}

Des lapins (blancs de Nouvelle-Zélande) sont infectés par inoculation intraveineuse de $1 \mathrm{ml}$ de suspension du virus bovipestique lapinisé Nakamura III, représentant approximativement cent doses infectantes. Trois autres inoculations sont réalisées dans la semaine et des prélèvements de sang sont effectués sur les lapins le huitième, le douzième et le quatorzième jour après la dernière inoculation. Les sérums sont mélangés et stockés à - $40^{\circ} \mathrm{C}$. Avant usage, le sérum est chauffé à $56^{\circ} \mathrm{C}$ pendant 30 minutes.

Des sérums de contrôle sont collectés à partir de lapins normaux.

\section{- Antigène.}

Les ganglions lymphatiques mésentériques sont prélevés sur un bovin sacrifié, dans l'expérience de STONE et MOULTON, quatre jours après le début de la maladie. Les ganglions sont débarrassés de leur graisse, découpés en petıts morceaux avec des ciseaux et homogénéisés dans un mixer pendant 10 minutes avec un poids égal de tampon phosphaté. Ce tampon phosphaté contient $5,52 \mathrm{~g}$ de phosphate monosodique, $9,56 \mathrm{~g}$ de phosphate disodique par litre et possède un $\mathrm{pH}$ de 6,8 . Le mélange abtenu après mixage est centrifugé pendant 30 minutes à 3.000 tours/mn à une température de $0-5^{\circ} \mathrm{C}$.

Après la centrifugation, trois couches distinctes sont visibles dans le tube : un bouchon graisseux sur le dessus, une couche liquide brûne opaque dans le miliev et un sédiment au fond.

La couche médiane est récupérée avec soin en évitant les soullures avec la couche graisseuse : elle est centrifugée alors à 10.000 tours/mn pendant 30 mınutes. II apparaît encore, moins nettement cependant, trois couches différentes. La couche médiane est récoltée ef représente l'antigène dilué au 1/2. Des ganglions lymphatiques mésentériques d'animaux normaux sont traités de la même façon et servent d'antigène de contrôle.

\section{- Complément.}

STONE et MOULTON utilisent du sérum frais de cobaye stocké à - $40^{\circ} \mathrm{C}$, mais comme pour. la technique de COWAN, le complément lyophilisé est préférable dans les conditions climatiques de I'Afrique centrale.

\section{- Tubes utilisés dans la réaction de déviation du C'.}

Des tubes de 7,5 par $10 \mathrm{~mm}$ contenant des globules rouges hémolysés sont calibrés à une longueur d'onde de 541 angströms dans un spectrophotomètre Beckman DU. Tous les tubes, dont la densité optique varie de plus de 5 p. 100 , sont rejetés.

\section{- Système hémolytique.}

Du sang de mouton est recueilli aseptiquement dans un volume égal de solution d'Alsever stérile et entreposée à $2^{\circ} \mathrm{C}$.

La solution d'Alsever est composée de $20,5 \mathrm{~g}$ de glucose, $8 \mathrm{~g}$ de citrate de soude, 4,2 g de chlorure de sodium, dissous dans $1.000 \mathrm{mi}$ d'eau distillée. Le pH est ajusté à 6,1 avec une solution d'acide citrique à 5 p. 100 .

La stérilisation est réalisée en chauffant cette solution trois jours de suite pendant 30 minutes à $100 \mathrm{o}$.

La suspension de globules rouges en Alsever est centrifugée à 1.000 tours/mn pendant 10 minutes et lavée trois fois dans 10 fois son volume de tampon véronal. Une suspension à 5 p. 100 est constituée en ajoutant $1 \mathrm{ml}$ de culot de centrifugation à $19 \mathrm{ml}$ de tampon véronal*.

Un millilitre de cette suspension est alors lysé dans $14 \mathrm{ml}$ d'une solution à 0,1 p. 100 de carbonate disodique. La densité optique de la solution rouge clair ainsi obtenve est déterminée au spectro-

* Le tampon véronal utilisé ıcı contient 0,1 pour cent de gélatine. 
photomètre Beckman DU à une longueur d'onde de 541 angströms dans des cuves de $10 \mathrm{~mm}$ avec une solution de carbonate disodique à 0,1 p. 100 comme référence, Dans ces conditions, une densité optique de 0,68 correspond à la présence de $10^{9}$ cellules par millilitre de la suspension originale à 5 p. 100 de globules rouges.

Quand la densité optique est trop forte, du tampon véronal est ajouté à la suspension.d'hématies à 5 p. 100.

Pour connaître la quantité de tampon véronal à ajouter, il convient d'appliquer la formule suivante :

Si $\mathrm{OD}_{1}$ est la densité optique de la suspension d'hématies à 5 p. 100 lue au spectrophotomètre, $V_{1}$ le volume restant de la suspension initiale de globules rouges après avoir enlevé les $1 \mathrm{ml}$, soił $19 \mathrm{ml}$, et $V_{2}$ le volume final à réaliser pour avoir $10^{\circ}$ cellules par $\mathrm{ml}$ de cette suspension :

$$
\frac{O D_{1}}{0,680} \times V_{1}=V_{2}
$$

Une fois la suspension de globules rouges ajustée, on y ajoute un égal volume d'une dilution appropriée de sérum hémolytique de lapin selon la méthode d'OSLER.

Ce sérum hémolytique est préparé en administrant à des lapins douze inoculations intraveineuses, trois par semaine, de stroma d'hématies de mouton lavées et bouillies 20 minutes; les quantités inoculées vont en croissant, avec $0,5 \mathrm{ml}$ au début, et $4 \mathrm{ml}$ à la fin. Cinq jours après la dernière injection, les lapins sont saignés par ponction cardiaque. Les sérums sont chauffés individuellement 30 minutes à $56^{\circ}$ et conservés à $-40^{\circ} \mathrm{C}$.

\section{- Techniques.}

STONE et MOULTON envisagent deux techniques différentes.

10 Fixation du complément avec des dilutions de l'antigène :

Le sérum de lapin hyperimmun et les différentes dilutions de l'antigène entrent dans la réaction sous un volume de $0,4 \mathrm{ml}$. Le sérum de lapin hyperimmun esł dilué au $1 / 40$; l'antigène au 1/40,1/60, $1 / 80,1 / 100,1 / 120$, tandis que le complément est dilué de façon à avoir cinq unités hémolytiques $50 \mathrm{p} .100$ sous un volume de $0,5 \mathrm{ml}$. Le pouvoir anticomplémentaire de chaque antigène essayé est déterminé pour la plus faible dilutıon de l'antigène, soit le $1 / 40$, en présence de $1,2,3,4$ et 5 unités hémolytiques 50 p. 100 de complément.

La fixation peut se faire aussi bien une heure à $38^{\circ} \mathrm{C}$ qu'une nuit à $5^{\circ} \mathrm{C}$. La lecture est faite après addition de $0,2 \mathrm{ml}$ de globules rouges sensibilisés ( $10^{B}$ cellules) à chaque tube et incubation pendant 30 minutes à $37^{\circ} \mathrm{C}$.

Tous les tubes sont centrifugés pendant 10 minutes à 1.000 tours/mn, et le degré d'hémolyse est estimé visuellement par comparaison avec des tubes contenant 25,50 et 75 p. 100 d'hématies complètement hémolysées.

Les tubes hémalysés à 50 p. 100 sont désignés par le chiffre 2 ; la lecture s'arrête à ces tubes.

20 Fixation du complément avec des dilutions de complément.

Dans cette technique, l'antigène et le sérum hyperimmun sont utilisés à concentration constante tandis que le complément intervient à des dilutions variables.

Une solution stock de complément est utilisée ; elle est constituée habituellement par du complément dilué au $1 / 30$. Puis des sous-dilutions contenant $0,6,9,13,20,45$ et $67 \mathrm{p}$. 100 de cette solutionstock sont réalisées.

La réaction de fixation du complément se fait ici en quatre séries de tubes.

Chaque série comprend neuf tubes qui correspondent chacun à une sous-dilution de la solution stock de complément.

Dans la première série, les tubes contiennent $1 \mathrm{ml}$ de chaque sous-dilution de complément, $0,4 \mathrm{ml}$ d'antigène et $0,4 \mathrm{ml}$ de sérum ; c'est la série réaction.

Les trois autres séries sont les sérıes témoıns. 
Dans la deuxième série, les $0,4 \mathrm{ml}$ de sérum sont remplacés par $0,4 \mathrm{ml}$ de tampon véronal, les autres constituants étant inchangés.

Dans la troisième série, ce sont les $0,4 \mathrm{ml}$ d'antigène qui sont remplacés par $0,4 \mathrm{ml}$ de tampon véronal, le complément et le sérum restant inchangés.

Enfin dans la quatrième série, seul le complément reste, le sérum ef l'antigène sont remplacés dans chaque tube par $0,8 \mathrm{ml}$ de tampon véronal.

Dans chaque série, le 1 er tube qui ne contient pas de complément ( 0 p. 100 de la solution-słock) sert à contrôler le pouvoir hémolytique de chaque facteur de la réaction.

TABLEAU 5

Technique $n^{\circ} 1$ de Stone et 'Moulton

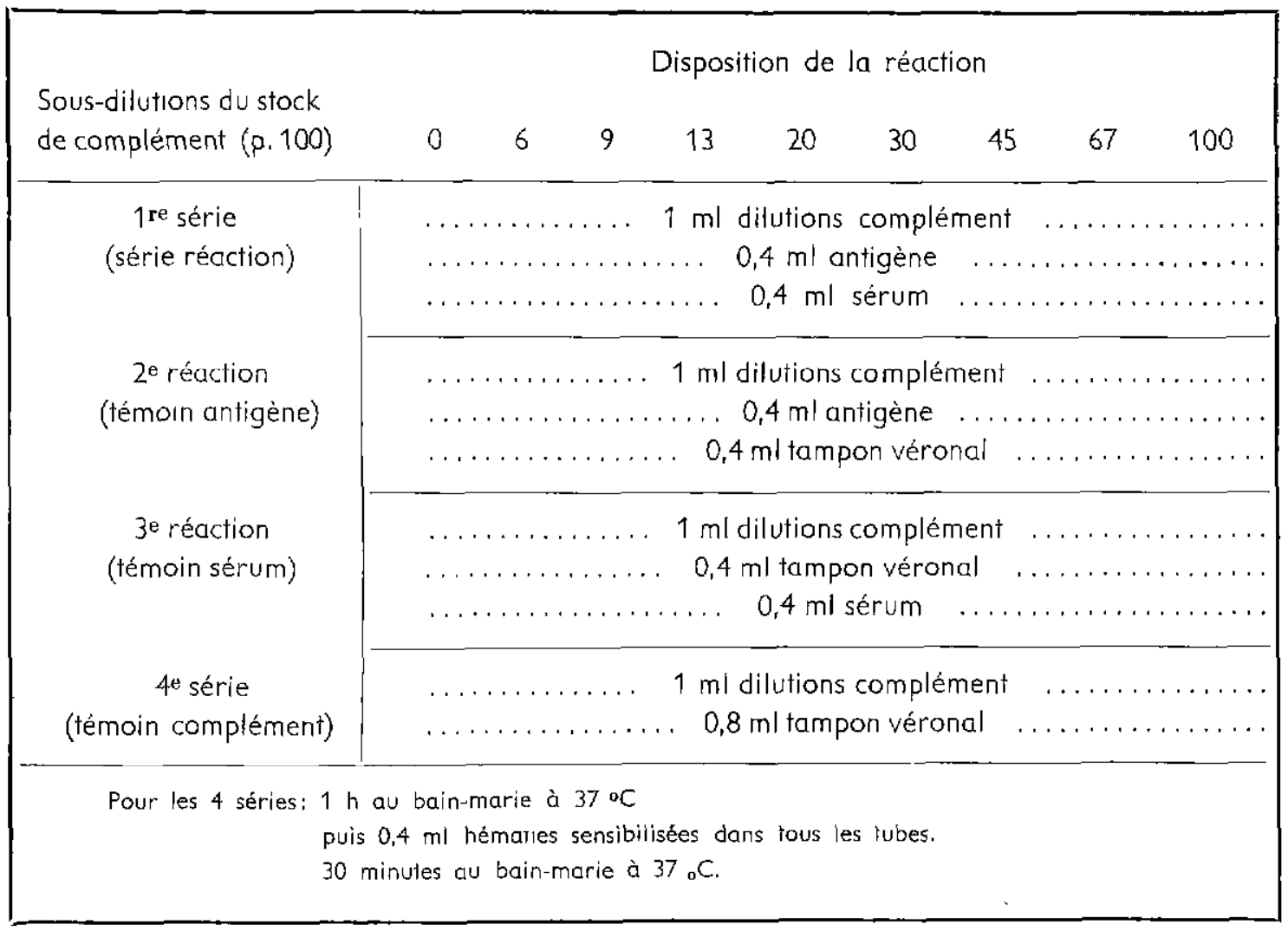

Après incubation au bain-marie à $37{ }^{\circ} \mathrm{C}$ pendant une heure, $0,4 \mathrm{ml}$ d'hématies de mouton sensibilisées sont djoutés à chaque tube. L'incubation est reprise pendant 30 minutes à 37 oC, puis les fubes sont centrifugés à 1.000 tours/mn pendant 10 minutes. Le degré d'hémolyse est déterminé dans un spectrophotomètre Beckman DU à une longueur d'onde de 541 angströms. Le pourcentage d'hémolyse est calculé, converti en probits et porté en ordonnée sur un graphique. Les logarithmes correspondants aux sous-dilutions de la solution stock de complément sont portés en abscisse ; la courbe expérimentale est tracée et le logarithme de C' qui donnerait l'hémolyse 50 p. 100 est déterminé : par le point où la courbe expérimentale coupe l'horizontale menée par le probit 5 , on trace une perpendiculaire qui coupe l'axe des abscisses au point cherché.

STONE et MOULTON ont montré que dans cette technique le sérum hyperimmun dilué au 1/40 fixe le complément au maximum et perd le pouvoir anticomplémentaire qu'il pouvait avair aux basses dilutions. De même, la dilution d'antigène au $1 / 40$ est suffisante pour éviter l'effet de prozone des 
basses dilutions, ef apporter en outre suffisamment de matériel pour avoir une fixation maximale de complément.

Le logarithme de la dilution du complément qui donne 50 p. 100 d'hémolyse est déterminé en présence de l'antigène seul et en présence du complexe antigène-sérum. Ces logarithmes sont ensuite convertis en antilogarithmes qui représentent les volumes de complément nécessaires pour obtenir 50 p. 100 d'hémolyse. La différence entre ces volumes montre la quantité de complément fixée par le système antıgène-sérum.

Cette quantité est nulle s'il n'y a pas correspondance entre l'antigène ef le sérum mis en présence, c'est-à-dire, si d'une part, le sérum ne contient pas d'anticorps (cas du sérum de contrôle collecté à partir de lapins normaux), d'autre part, si l'antigène ne correspond pas aux anticorps contenus dans le sérum.

L'antigène bovipestique spécifique dans le prélèvement suspéct est révélé par une certaine fixation du complément avec le sérum hyperimmun, fixation qui sera nulle si le prélèvement suspect ne contient pas cet antigène.

\section{B. Mise en évidence des anticorps.}

Les difficultés, pour mettre en évidence les antıcorps viraux dans les sérums de bovins par fixation du complément sont à l'heure actuelle trop importantes, et les résultats trop inconstants, pour que l'on puisse songer à utıliser cette technique comme méthode diagnostic.

Un test indırect semblable à celui utilısé pour la mıse en évidence des anticorps dans le sérum de bovins convalescents de fièvre aphteuse apporterait une solution, mais il reste à être précisé. 
FICHE TECHNIQUE No 6

\section{la réaction de pRécipitation en gélose *}

1ег TEMPS

\section{PRÉPARATION DES ANTIGĖNES DE RÉFÉRENCE}

\section{Matériel.}

I. - Matériel d̀ stériliser a l'autoclove (ou à défaut par ébullition dans l'eau)

- 1 seringue de $20 \mathrm{cc}$

- Aiguilles 4-8/10

- $100 \mathrm{ml}$ d'eau distillée

- 2 litres de sérum physiologique

- Bol de 1 litre en verre de mixeur Turmix

- 8 bocaux de verre (genre bocaux à confiture)

- 1 éprouvette de 11

- Bouchons de caoutchouc pour flacons $2 \mathrm{cc}$.

2. - Matériel à stérilıser au four

- Couteau à autopsie

- Boîte à instruments comprenant : 1 bistour, 1 pince à dents de souris $17 \mathrm{~cm}$,

1 pince en cœur,

- 1 plateau émaillé

1 paire de ciseaux.

- 1 entonnoir de $1 \mathrm{I}$, monté avec une double couche de gaze

- 1 ballon de 500 cc ou 11

- 1.000 flacons de 2 cc ou 1.000 ampoules 2 ec fond plat

- 5 boîtes de Petri, diamètre $10 \mathrm{~cm}$

- 10 tubes, diamètre $16 \mathrm{~mm}$

- 6 pipettes graduées de $5 \mathrm{cc}$

- Canne de verre pour pipettes Pasteur.

3. - Produls chimiques

- Alcool à $95^{\circ}$ (ou 900)

- Chlorure de sodium

4. - Matériel divers

- Ciseaux courbes de $17 \mathrm{~cm}$

- Numéros d'identification (ou peınture à l'huile et pinceau)

* La réaction de précipitation en milieu gélifié utilisant la méthode des disques n'est pas décrite ici. On se reporlera à la publıcation originale de A. Provost et coll. : Recherches sur une méthode rapide de diagnostic de la peste bovine, publiée dans cette Revue (16, no $3 ; 287-95$ ). 
- Thermomètre médical au $1 / 10^{\mathrm{e}}$

- Rhéomètres de 2 et $5 \mathrm{cc}$.

- Crayon à verre

- Réfrigérateur - si possible, freezer à - $20^{\circ} \mathrm{C}$

- Agar cutters (ou tubes de verre, de paroi de $5 / 10 \mathrm{~mm}$ d'épaisseur, et de diamètre intérieur de $5 \mathrm{~mm}$; par exemple : col d'ampoule à vaccin).

5. - Produits brologiques

- Gélose pour précipitation

- Sérum de lapin, antipestique de référence

- Virus capripestique (CAPRISEC).

6. - Anımoux

-8 chevreaux (ou 8 veaux).

\section{Protocole.}

Dans les territoires où n'existe pas la peste bovine, la sécurité impose de n'y pas manipuler de virus virulent. Par ailleurs, dans ceux qui à l'heure actụelle sont l'objet (ou vont l'être dans un avenir très rapproché) de campagnes d'éradication de peste, on aura vraisemblablement d'assez grandes difficultés à se procurer des veaux réceptifs. Pour ces raisons, il semble préférable de préparer les antigènes de référence à partır de chèvres et de virus capripestique. On pourrait également, si l'on était sûr de la réceptivité des vequx, inoculer des veaux avec le virus capripestique. La technique décrite est valable pour le lapin ef le virus lapinisé ; il n'y a qu'une transposition de mots à faire. Un tel antigène n'est toutefois pas recommandé à cause des précipitations non spécifiques qui peuvent se produire entre ces antigènes et leș immuns sérums de lapin.

jour 0 . - Choisir 8 chevreaux âgés de 8 mois à 1 an, en bonne santé apparente, ne foussant et ne mouchant pas (pleuro-pneumonie contagieuse). On a avantage à choisir les animaux des races sahélierines (poil long, oreilles tombantes) plutôt que ceux de race dite guinéenne (poil ras, oreilles dressées) dont la réceptivité au virus capripestique est douteuse.

Loger les animaux très à l'aise : enclos spacieux, equ et fourrage à discrétion, quelques branches d'acacia ou d'un arbre épineux. Si le temps est frais (tornade ou saison fraîche) ne pas hésiter à mettre un brasero dans l'enclos. Les numéroter (numéros à l'oreille, numéros à la peinture). Prendre les températures le matin de très bonne heure, dès le lever du soleil. Désinfecter les thermomètres d l'alcool entre chaque prise de température. Reporter les températures sur un graphique. N'inoculer que les chèvres dont la température est inférieure à $39^{\circ} \mathrm{C}$. Eliminer impitoyablement les autres, suspectes d'être atteintes de pleuro-pneumonie.

- A l'aide d'une seringue de $20 \mathrm{cc}$ remplie d'eau distillée stérile et munie d'une aiguille 4-8/10, perforer le bouchon d'un flacon de vaccin antipestique caprinisé *. L'e liquide doit être attiré dans le flacon par le vide relatıf qui y règne. S'il n'en est pas ainsi, rejeter le flacon et en prendre un autre.

La dissolution du' produif lyophilisé est immédiate ; inoculer $1 \mathrm{mll}$ à 5 chèvres par volé souscutanée. II resie donc 3 chèvres non inoculées,

- détruire le reste du virus et désinfecter le matériel par ébullıtion.

Jours 1 à 5. - Prendre la température tous les matins juste après le lever du soleil. Désınfecter les thermomètres. Reporter les températures sur un graphique.

La réaction thermique s'amorce les jours 3 ou 4 : elle est nette 24 heures plus tard : minimum thermique de $40^{\circ} \mathrm{C}$ et écart d'au moins $1,5^{\circ} \mathrm{C}$ entre la température du jour 0 et celle des jours 4 ou 5. $\mathrm{Ne}$ conserver que les chèvres inoculées qui safísfont à ce critère. Les 3 chèvres non inoculées doivent avoır une température étale. S'il n'en est pas ainsı, ne pas les utiliser par la suite.

* CAPRISEC du Laborataire de Farcha; CAPRIBOVIPESTE du Laboratoire de Dakar. 


\section{Jour 6.}

1. - Abattre les chèvres par égorgement et saignée, en commençant par les chèvres non inoculées.

Lever la peau. A l'aide des outils stériles appropriés (pinces à dents de souris, bistouri, ciseaux) prélever le plus proprement possible les ganglions lymphatiques superficiels : préaxillaires, précruraux, inguinaux, poplıtés. Les mettre dans un récipient stérile (boîte de Pétri ou jarre de verre).

Luxer les artículations coxofémorales pour maintenir le cadavre sur le dos. Lever les épaules. prélever les ganglions sous-axillaires.

Inciser la ligne blanche. Eviscérer; conserver les viscères. Prélever les ganglions inguinaux profonds, rénaux et lombo-aortiques. Sur les viscères, prélever les ganglıons mésentériques (sur la chèvre, c'est une longue masse d'une dizaine de cm, adjacente à la courbure interne de l'iléum).

Ouvrir la cage thoracique et constater le bon état du poumon. Toute pneumonie en évolution entraîne le rejet de la récolte ; il doit en être de même des infarcissements pseudo-hémorragiques des lobes apicaux (pneumonie néo-rickettsienne).

Dès que l'on en a terminé avec un animal, mettre la récolte sous froid. Ne pas mélanger les récoltes venant des chèvres infectées ef non infectées.

2. - Préparation de l'antigène. La préparation de l'antigène négatif (chèvres non inoculées) et positif (chèvres inoculées) est la même. On débutera par l'antigène négatif.

Dans un plateau émaillé, débarrasser les ganglions du conjonctıf, de la graisse qui les entourent. Décapsuler soigneusement. Mélanger les récoltes (3 prélèvements négatifs ou 5 prélèvements positıfs).

Peser, noter le poids.

Introduire les ganglions dans le bol de verre d'un mixeur Turmix.

Ajouter les $2 / 3$ en volume de sérum physiologique (c'est-à-dire ganglions : 1 partie en pords ; sérum physialogique : 2 parties en volume) mesuré à l'aide d'une éprouvette. Fermer le bol du Turmix et maintenir fermement le couvercle à la main. Passer directement sur la vitesse 3 . Emulsionner 3 minutes en arrêtant de temps à autre pour ne pas faire chauffer trop le moteur.

Passer le broyat homogénéisé sur un entonnoir de 2 I équipé d'une double couche de gaze. Ne recueillir dans un récipient entouré de glace que ce qui passe au travers de la gaze.

A l'aide d'un rhéomètre calibré, répartir à raison de $2 \mathrm{ml}$ dans de petits flacons ou de petites ampoules stériles, maintenues sur de la glace fondante. Conserver $10 \mathrm{ml}$ de l'antigène positif pour titrage immédiat. Fermer les flacons au bouchon de caoutchouc ou sceller les ampoules. Etiqueter au sparadrap en écrivant au crayon à bille : antigène capripestique positıf (ou négatif) de référence : dater.

Congeler immédiatement à $-20^{\circ} \mathrm{C}$ ou à défaut, dans le freezer d'un réfrigérateur. tion.

3. - Titrage de l'antigène positif. Ce titrage doit être mené en même temps que se fałt la réparti-

a) Préparer 4 boîtes de Pétri avec gélose à précipitation et cupules ainsi qu'il est dıt plus loin. Avec le crayon à verre, noter les dilutions d'antigènes selon le schéma ci-jaint.

b) Disposer sur un portoir 5 tubes de 16. Porter dans chacun d'eux $5 \mathrm{ml}$ de sérum physiologique, à l'aide d'une pipette. Marquer dans l'ordre les tubes: $1 / 2,1 / 4,1 / 8,1 / 16,1 / 32$.

c) A l'aide d'une pipette de $5 \mathrm{cc}$, prélever $5 \mathrm{ml}$ de l'antigène et le porter dans le tube marqué $1 / 2$. Bien mélanger en aspirant ef refoulant plusieurs foss.

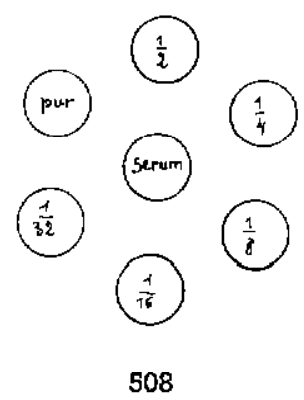


Prendre une nouvelle pipette. Prélever $5 \mathrm{ml}$ du mélange $1 / 2$ ef le porter dans le tube marqué $1 / 4$. Opérer comme précédemment... Ainsi de suite jusqu'au tube $1 / 32$.

(Si l'on possède un rhéomètre, on peut faire les dilutions à l'aide de celvi-ci).

d) A l'arde de pipettes Pasteur, remplir les cupules destinées aux différentes dilutions dans les 4 boîtes de gélose, selon le schéma ci-dessus. Changer de pipettes pour chaque dilution.

Répartir le sérum de référence dans les 4 cupules centrales.

Refermer les boites.

e) Si la température moyenne de la pièce est supérieure à $35^{\circ} \mathrm{C}$, porter les boites de Pétrı dans la partie basse d'un réfrigérateur. Si la température oscille entre 20 et 30 C , laisser les boîtes sur la paillasse du laboratoire.

Jour 7 ef 8 . - Lire les précipitations au bout de 24 et de 48 heures.

L'antigène est acceptable lorsque les bandes des précipitations existent dans les 4 boîtes, en face des cupules: $1 / 2,1 / 4,1 / 8$ et dans 2 boîtes au moins en face des cupules : $1 / 16$ (il est possible qu'i! existe une bande de précipitation en face des cupules:1/32). On dit alors que le titre précipitant 50 p. 100 de l'antigène est $1 / 16$.

4. Epreuve de l'antıgène négatif. - Procéder comme il vient d'être décrıt sous la rubrique jour 6-3 pour l'antigène positif, mais n'opérer que sur une seule boîte de Pétri. Il ne doił y avoır aucune précipitation.

Remarque 1. - Lyophilisation de l'antigène. Si l'on possède un appareil à lyophiliser, on peut avec avantage lyophiliser l'antigène de référence. On prendra soin de le répartir dans des flacons ou des ampoules de capacité sensiblement double de celle du volume $(2 \mathrm{ml})$ à lyophiliser. Boucher ou sceller sous vide. Lors de la reconstitution, reprendre dans le volume primitif avant lyophilisation.

Remarque 2. - La technique de l'antigène desséché de SCOTT et BROWN pourrait être employée avec fruit; elle a l'avantage de donner un produit très stable. Mais, réclamant pour sa réalisation du pentoxyde de phosphore, elle semble difficile à mettre en œuvre en Afrique occidentale et centrale.

\section{2 e TEMPS}

\section{PRÉPARATION D'UN SÉRUM ANTIBOVIPESTIQUE PRÉCIPITANT DE RÉFÉRENCE}

\section{I. - PRÉPARATION DU MATÉRIEL VIRULENT}

\section{Matériel.}

1. - Matériel d stériliser d l'autoclove (ou à défaut, par ébullition dans l'eau).

- 1 seringue $20 \mathrm{cc}$

- 1 seringue 1 ou 2 cc

- Aiguilles 3-8/10

- Aiguilles 4-6/10

- Boîte de Pétri

- Mortier avec pilon, ou bróyeur de verre genre Tissue grınder

- Pots à centrifuger

- Flacons 10 ou $20 \mathrm{cc}$ avec leurs bouchons de caoutchouc

- 1 I de sérum physiologique. 
2. - Matériel d̀ stériliser au four (Four Pasteur, ou à défaut four de cuisinière)

- Cannes de verre de $25 \mathrm{~cm}$, bouchées au coton aux 2 extrémités (pour pipettes Pasteur)

- Boîte à instruments comprenant au minimum :

- 2 pinces à dents de souris, longueur $14 \mathrm{~cm}$

- 1 bistouri convexe

- 1 ciseau courbe longueur $12 \mathrm{~cm}$

- Quelques tubes à essai contenant du sable.

3. - Produits chimiques.

- Alcool d̀ $95^{\circ}$ (ou 900)

- Alcool iodé ou tout autre antiseptique de contact

- chiorure de sodium

- Pénicillıne - streptomycine.

4. - Matériel accessoire.

- Boîte à contention (facultative)

- Coton hydrophile

- Thermomètre médical au $1 / 10$

- Cages à lapin avec mangeoires

- Graphiques de température

- Plateau à autopsie et cordelette ou planche de bois, clous et marteau

- Rasoir et savon

- Balance ordinaire

- Centrifugeuse de laboratoire (facultative)

- Sparadrap : crayon à bille

- Réfrigérateur avec freezer accessible ef bacs à glace.

5. - Animaux.

-1 lapin.

\section{Protocole:}

Jour 0. - Choisır un lapin neuf de $2 \mathrm{~kg}$ environ, âgé d'au minimum 4 mois, en bon état de santé. Prendre la température.

- Diluer 1 flacon de virus bovipestique lapinisé * dans $20 \mathrm{ml}$ de sérum physiologique. A cet effet, introduire le diluant à l'aide d'une seringue montée d'une aiguille et contenant la quantité 'rèquise : perforer le bouchon à l'aide de l'aiguille ; le liquide doit être absorbé par le vide relatif existant dans le flacon. S'il n'en est pas ainsi, rejeter le flacon et en prendre un autre. gène.

- La dissolution demande quelques secondes. Le produit obtenu par dissolution doit être homo-

- Placer le lapin dans une boite à contention. Arracher les poils sur une veine auriculaire externe et désinfecter.

- A l'aide d'une seringue de petit calibre (1 ou $2 c c$ ) et d'une aiguille 4-6/10, injecter, par voie intraveineuse, $1 \mathrm{ml}$ de la suspension reconstituée de virus lapinisé.

* LAPISEC du laboratoire de Recherches vétérinaires de Farcha ; CU NIBOVIPESTE, du Laboratoire de Recherches vétérinaires de Dakor. 
- Conserver le reste du virus dilué au freezer (réserve en cas de faute opératoire).

- Mettre le lapin en observation.

- Désinfecter le matériel usagé par ébullition.

Jour $J+1, J+2 .-$ Prendre la température du lapin le matin de très bonne heure et désinfecter le thermomètre à l'alcool avant ef après usage.

jour $\mathrm{J}+$ 3. - Prendre la température comme précédemment. Etablir la courbe de température. Une réaction thermique extrêmement nette doit se manifester : montée de plus $2^{\circ} \mathrm{C}$, avec mi nimum à $40^{\circ} \mathrm{C}$, le maximum pouvant atteindre $41,5^{\circ} \mathrm{C}$.

Préparer une solution physiologique additionnée d'antibiotiques, du type suivant (respecter les proportions si l'on en désire moins) :

- Spécilline G

1.000 .000 unités

- Didromycine

1 gramme

- Sérum physiologique $\ldots \ldots \ldots \ldots \ldots \ldots \ldots \ldots \ldots \ldots \ldots$

1 litre

La placer au réfrigérateur.

- Peser une boîte de Pétri, noter le poids, la placer dans le freezer d'un réfrigérateur.

- Réfrigérer de la même façon : mortier et pilon, ou broyeur de Pyrex, pots à centrifuger, flacons de $20 \mathrm{cc}$.

4. - Placer le lapin dans la boîte à contention.

5. - Inoculer très ropidement par voie intraveineuse $20 \mathrm{ml}$ d'air (aiguille 4-6/10). Le lapın meurt d'embolie gazeuse dans les secondes suivantes.

6. - Le placer sur le dos dans un plateau à autopsie, ef l'attacher les membres en croix. Plus sommairement, on peut le clover les membres en croix sur une planche.

7. - Raser sommairement l'abdomen. Badigeonner d'une solution antiseptique (anabac, alcool iodé).

8. - Ouvrir l'abdomen en 2 temps : peau, puis plan muscuiaire que l'on récline sur le côté. Rejeter les outils (bistouri et pince) dont on vient de se servir. Puis, dans l'ordre :

9. - Prélever la rate, avec le minimum de graisse; pour cela, débrider au long de l'organe suivant la petite courbure. Placer dans la boîte de Pétri tarée, préalablement réfrigérée, que l'on conserve sur de la glace.

- Récliner la masse intestinale sur la droite. Saisir avec la pince l'extrémité libre de l'appendice et débrider l'insertion appendice-iléon en prenant bien garde de ne pas couper ce dernier. Cette opération étant faite, on tombe sur la masse ganglionnaire mésentérique dans le prolongement de l'appendice.

La prélever avec le minimum de graisse et la placer avec la rate dans la boîte de Pétri.

- L'appendice étant saisi à l'aide de la pince par son extrémité libre, on chasse son contenu à l'aide des ciseaux, et on la sectionne à l'endroit aù se termine la masse lymphatique. Le placer dans la boîte de Pétri.

- Le lapin peut être consommé sans danger.

10. - Peser la boîte pleine, après avoir essuyé l'eau de fonte de la glace présente sur le fond. 'En déduire par différence le poids des organes récoltés. Les conserver sous froid (freezer d'un réfrigérateur) en attendant la suite des opérations.

11. - Découper rate, ganglions, et appendice en menus fragments. Les broyer avec du sable dans le mortier ou dans un broyeur de Pyrex genre Ten-Broek (Tissue grinder).

- Ajouter un volume en $\mathrm{ml}$ de sérum physiologique (additionné d'antibiotiques) glacé égal à 2 fois le poids en $\mathrm{g}$ d’organes calculé précédemment. Bien homogénéiser. 
12. - Si l'on dispose d'une centrifugeuse, centrifuger très légèrement pour sédimenter les gros débris. Si l'on n'en possède pas, laisser une dizaine de minutes au réfrigérateur et aspirer le surnageant avec une pipette Pasteur.

13. - Dans les flacons de 10 ou $20 \mathrm{cc}$, répartir :

- Dans 6 flacons : $1 \mathrm{ml}$ de suspension virulente

- Dans 3 flaçons : $2 \mathrm{ml}$ de suspension virulente

- Dans 3 flacons : $4 \mathrm{ml}$ de suspension virulente.

Boucher au bouchon de caoutchouc. Etiqueter en se servant de sparadrap et d'un stylo à bille.

14. - Placer immédiatement à la température la plus basse possible dont on dispose.

Nota : Le protocole a été détaillé pour 1 lapin inoculé, qui fournitla matériel suffisant à l'hyperimmunisation de 3 autres lapins qui pourront fournir $60 \mathrm{mi}$ de sérum précipitant.

Il y a intérêt à ne pas conserver plus de 6 mois ce sérum précipitant ; c'est dire qu'un laboratoire courant préfèrera faire une nouvelle production de sérum avec 3 nouveaux lapins plutôt qu'en préparer un gros stock d'emblée.

\section{II. - HYPERIMMUNISATION DES LAPINS}

\section{Małériel.}

1. - Matériel d̀ stérihser à l'autociave (ou à défaut par ébullition dans l'eau),

-1 seringue $1 \mathrm{cc}$

- 1 seringue $5 \mathrm{cc}$

-1 seringue $20 \mathrm{cc}$

-1 aiguille $4-6 / 10$

- 3 aiguilies $4-8 / 10$

- 3 aiguilles 5-10/10

- 1 litre de sérum physiologique

2. - Matériel d stériliser au four Pasteur (ou d̀ défout dans un four de cuisinière).

- 4 ballons de 50 ou 100 cc à large ouverture, bouchés d'un tampon de gaze

- Canne de verre pour pipettes Pasteur

- 12 tubes à hémolyse

- 16 pipettes de 1 cc

- 3 boîtes de Petri, diamètre $10 \mathrm{~cm}$

- Tubes de verre à fond rond, verre mince, diamètre $5 \mathrm{~mm}$.

3. - Produits chimiques.

- Alcool d̀ 950

- Chlorure de sodium ou sérum physiologique.

4. - Matériel accessoire.

- Balance Roberval

- Numéros pour petits animaux 
- Coton hydrophile

- Crayon à verre (ou sparadrap et crayon à bille)

- Réfrigérateur

- Centrifugeuse avec pots et godets

- Agar cutters (voir lıste de matériel) ou tube de verre de diamètre intérıeur $5 \mathrm{~mm}$, à paroi de $5 / 10 \mathrm{~mm}$ d'épaisseur : col d'ampoule à vaccin par exemple.

5. - Animoux.

- 3 lapins.

6. - Motériel biologique.

- Immunsérum antipestique *

- Antigènes pestiques de référence (positifs et négatifs)

- Gélose à précipitation.

\section{Protocole.}

Jour 0. - Choisir 3 lapins de 1,5 à $2 \mathrm{~kg}$ en bonne santé. Les peser et numéroter à l'oreille.

A l'aide d'une seringue montée d'une aiguille 4-6/10, inoculer à chaque lapin par voie intraveineuse $2 \mathrm{ml}$ par $\mathrm{kg}$ de poids vif, de sérum de lapin antipestique hyperimmun.

Jour 1. - Inoculer à chaque lapın par voie intraveineuse $1 \mathrm{ml}$ de virus lapinisé récolté et conservé comme indiqué précédemment.

Jour 8. - Inoculer à chaque lapin par voie intrapéritonéale $1 \mathrm{ml}$ de virus.

jour 12. - Inoculer à chaque lapin par voie intrapéritonéale $2 \mathrm{ml}$ de virus.

Jouc 16. - Inoculer à chaque lapin par voie intrapéritonéale $4 \mathrm{ml}$ de virus.

jour 23. - Récolte des sérums.

10 Un aide tient le lapin par les oreilles, membres antérieurs accolés; on suspend un poids de $1 \mathrm{~kg}$ aux membres postérieurs. Arroser d'alcool à $95^{\circ}$ la poitrıne du lapin et arracher les poils de la région péristernale gauche.

Enfoncer d'un coup sec une aiguille stérile 5-10/10 dans l'avant-dernier espace intercostal gauche, très près du sternum et très verticalement. Arrêter la pénétration de l'aigulle dès que le plan musculocutané est franchi. On voit alors habituellement l'aiguille « danser » sur la pointe du cœur. Enfoncer d'environ $1 \mathrm{~cm}$. Le sang jaillit avec force. En recueillir $5 \mathrm{ml}$ environ dans un ballon stérile à large ouverture. Dès que l'on a la quantité requise, retirer l'aiguille. Boucher stérilement le ballon. Remettre le lapin dans sa cage.

Faire de même pour chacun des 3 autres lapins, les sangs étant recueillis dans des récipients séparés.

$2^{\circ}$ Laisser coaguler le sang à température ordinaire pendant 30 minutes environ, puis laisser exsuder au réfrigérateur pendant 2 heures. Recueillir le sérum surnageant à l'aide d'une pipette Pasteur munie d'un embout de caoutchouc permettant l'aspıration. Si le sérum est chargé en hématies, centrifuger et recueillir le sérum clair surnageant (environ $2 \mathrm{ml}$ ).

3o Eprouver les qualités précipitantes du sérum par dilution du sérum et précipitation en gélose en présence d'antigènes pestiques (positifs et négatıfs) de référence.

* Ce sérum doit être un sérum de lopin el non de bceuf afin que les lapıns inoculés n'élaborent pas d'antıcorps antibouf. De petites quantités de ce sérum peuvent être demandées aux laboratoires de recherches vétérinaires de Farcha et de Dakar. 
-- Dilution du sérum : disposer 4 tubes à hémalyse, marqués 'au crayon gras $1 / 2,1 / 4,1 / 8,1 / 16$, sur un portoir et délivrer exactement dans chacun d'eux $1 \mathrm{ml}$ de sérum physiologique à l'aide d'une pipette de 1 cc ou d'un rhéomètre réglé sur cette capacité. A l'aide d'une autre pipette de $1 \mathrm{cc}$, prélever exactement $1 \mathrm{ml}$ du sérum et le porter dans le tube marqué $1 / 2$. Aspirer et refouler 6 fois afin de bien mélanger, en évitant toutefois de faire des bulles. On a ainsi la dilution $1 / 2$ du sérum.

A l'aide d'une nouvelle pipette de $1 \mathrm{cc}$. prélever $1 \mathrm{ml}$ dans ce tube et le porter dans le tube marqué $1 / 4 \ldots$ Ainsi de suite jusqu'à la dilution $1 / 16$.

- Préparer une boîte de Petri remplie de gélose à précipitałion (technique décrite dans le Temps: $n^{0}$ 3) et y creuser les cupules ad-hoc.

- Délivrer à l'aide de pipettes Pasteur chacune des dilutions de sérum dans les cupules, ainsi qu'il est schématisé ci-dessous. Remplir les cupules à ras bord sans faire déborder ; changer de pipette pour chaque dilution.

Délivrer ensuite (en changeant de pipette pour chacun d'eux) les antigènes pestiques positifs. et négatifs.

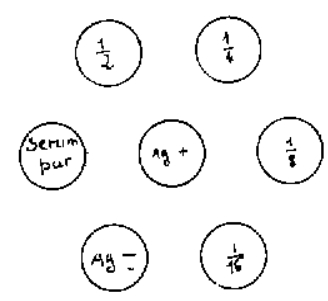

Refermer la boîte de Petri.

Faire de même pour chacun des 3 sérums.

Si la température moyenne de la pièce est supérieure à $35^{\circ} \mathrm{C}$ (cas fréquent en Afrique centrale pendant la saison sèche) porter la boîte de Petri dans la partie basse d'un réfrigérateur. Sı là température moyenne oscille entre 20 et $30^{\circ} \mathrm{C}$, laisser la boîte sur la paillasse du laboratoire.

jour 24. - Lire la précipitation au bout de 18 et 24 heures. On doit avoir la figure ci-dessous pour qu'un sérum soit acceptable. En particulier, il ne doit y avoir aucune précipitation en face du réservoir contenant l'antigène négatif.

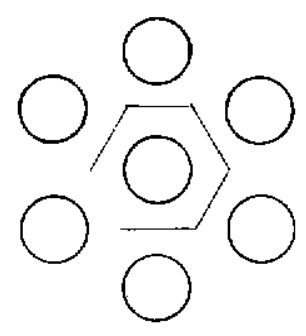

S'il en est ainsi, prélever $30 \mathrm{ml}$ de sang à chacun des lapins. On a intérêt à aspirer le sang avec une seringue de 20 cc lorsque l'aiguille a été poussée dans la cavité cardiaque.

Laisser coaguler à température ordinaire. Décoller et fragmenter les caillots à l'aide d'une baguette métallique. Porter au moins 24 heures au réfrigérateur. Aspirer avec précaution le sérum surnageant et le centrifuger s'il contient des hématies. Mélanger ensuite les sérums.

Répartir par quantités de $1 \mathrm{ml}$ dans de petıts fubes que l'on scellera à la flamme (à défaut, répartir dans des tronçons étirés de pipettes Pasteur. Congeler à $-20^{\circ} \mathrm{C}$ jusqu'à l'emploi désiré. Eviter les décongélations. 
Remorque - Si le laboratoire possède un appareil à lyophiliser, on a intérêt à lyophiliser les sérums précipitants. Pour la reconstitution, on prendra soin de les reconstituer dans le volume primitif ovec de l'eau distillée.

\section{3e TEMPS \\ PRÉPARATION DE LA GÉLOSE ET DES BOITTES}

Matériel.

- 1 récipient de 2 I environ

- 1 Erlenmeyer ou fiole de Fourneau de $500 \mathrm{cc}$

- 16 tubes Pyrex de $22 \mathrm{~mm}$ de diamètre ou 16 flacons à bouchon métallique à vis d'environ $30 \mathrm{cc}$

- 16 capuchons caoutchouc no 8

- 1 pince en bois

- 1 pipetie ou éprouvette de $25 \mathrm{cc}$

-1 agitateur

- 1 source de chaleur

Produits chimiques.

- Difco Noble agar

- Merthiolate

\section{Technique.}

10 Stériliser au four 16 tubes de $22 \mathrm{~mm}$, bouchés au coton et portant un repère extérieur au crayon à verre indiquant la capacité de $25 \mathrm{cc}$ (Au lieu de tubes de 22, on peut également utiliser des flacons de $30 \mathrm{ml}$ à bouchon métallique vissé).

$2^{\circ}$ Préparer un bain-marie d'un litre d'eau bouillante.

3o Peser :

$5 \mathrm{~g}$ de gélose spéciale Difco «Special Agar Noble»

$0,16 \mathrm{~g}$ de Merthiolate.

40 Mesurer $400 \mathrm{ml}$ d'eau distillée ou déionisée et les porter dans un Erlenmeyer ou une fiole de Fourneau de $500 \mathrm{cc}$.

Mettre au bain-marie bouillant.

50 Quand l'eau est chaude, verser la gélose en pluie fine en agitant avec un agitateur de verre pour éviter la formation de grumeaux. Ajouter le merthiolate. Continuer d'agiter jusqu'à dissolution complète (1 heure).

60 Répartir la gélose chaude dans les tubes ou les flacons jusqu'au trait repère. Fermer les tubes au coton, les flacons avec le bouchon vissé. et dater.

70 Capuchonner les tubes avec des capuchons de caoutchouc. Placer dans un panier. Etiqueter

$8^{\circ}$ Conserver au frigidaire ou à défaut à température ordinaire.

Remarque. Si l'on possède un $\mathrm{pH}$-mètre avec correcteur de température, on a avantage à ame- 
ner le $\mathrm{pH}$ de la gélose à 8,6 avec une solution de soude $1 \mathrm{M}$. Ce n'est toutefois pas une obligation pour avoir une gélose correcte mais le contrasłe des lignes de précipitation est augmenté.

Pour l'emploi de la gélose, se reporter au temps 5.

\section{TEMPS}

\section{PRÉPARATION DES ANTIGÈNES «SUSPECTS » POUR LE DIAGNOSTIC}

\section{Matériel.}

1. - Matériel stérilisé d l'autoclove ou par ébullition.

- Seringues de 5 ou 10 cc

- Aiguilles 3-12/10.

2. - Matériel stérilisé au four (four Pasteur ou de cuisinière).

- Couteau à autopsie

- Ciseaux pointus -- Pince à dents de souris, pince en cœur

- Mortier, pilon; ou tissue grinder

- Sable

- Boîtes de Petri

- Tubes d̀ hémolyse; tubes à centrifuger.

3. - Matériel courant.

- Bac à glace

- Bac à déchets

- Portoir

- Centrifugeuse (à main ou électrique)

- Ciseaux courbes

- Corde

- Coton.

4. - Produits chimiques.

- Alcool à $95^{\circ}$

- Crésyl ou antiseptique puissant.

\section{Technique.}

La technique est différente selon qu'il s'agit d'un cadavre (animal abattu ou mort naturellement) ou d'un animal vivant.

\section{A. - Cadarre.}

Si l'on peut choisir l'animal avant de l'abattre, le prendre en pleine phase d'évalution, et non au stade terminal de la peste.

Si l'on a affaire à plusieurs cadavres d'animaux morts naturellement, choisir celui qui est le moins décomposé.

- Faire l'autopsie seton la technique classique. 
- Prélever le ganglion mésentérique si le cadavre est frais, le ganglion poplité ou pré-scapulaire si le cadavre est partiellement putréfié. Les mettre dans un récipient étanche.

- Détruire le cadavre par incinération, enfouissement ou tout autre méthode. Désinfecter le couteau dans une solution antiseptique. Se désinfecter les mains et les faire désinfecter aux aides éventuels.

- Conserver la boîte de Petri contenant les ganglions dans la glace si l'on n'a pas l'intentıon de les traiter tout de suite (24-36 heures maximum).

- Décapsuler les ganglions, retirer soigneusement toute la graisse.

- Dans un mortier, découper le ganglion en tous petits fragments, que l'on émince le plus possible. Si cela est nécessaire (présence d'un conjonctif trop abondant), écraser avec un pilon et du sable ou broyer dans un «tissue grinder ». Ne pas ajouter d'eau. On obtient aınsi une sorte de pâte.

- Laisser reposer quelques instants. Si l'exsudation est suffisante, prélever un peu de liquide surnageant à l'aide d'une pipette Pasteur et le recueillır dans un tube à hémolyse.

- S'il n'y a aucune exsudation de liquide, ajouter un minimum d'eau ( $2 \mathrm{ml}$ pour un ganglion), mélanger puis centrifuger légèrement ( 20 minutes à 2.000 tours). Le surnageant constitue l'antigène suspect. II doit être conservé au froid et employé dans les minutes qui suivent.

Remarque. Si l'on ne dispose pas de centrifugeuse et qu'aucun liquide n'exsude lors du broyage, on se contentera de mettre un peu de purée ganglionnaire dans les cupules creusées dans la gélose (voir temps 5).

\section{B. - Animal vivant (ponction-biopsie).}

Immobiliser solidement l'animal ; au besoin, le coucher.

- Repérer à la main l'emplacement des 2 ganglions pré-scapulaires. Couper les poils. Désinfecter à l'alcool.

- D'une main immobiliser le ganglion, de l'autre introduire dans la substance ganglionnaire par perforation de la peau, une aıguille 3-12/10 montée sur une seringue de 5 ou $10 \mathrm{cc}$.

- Mancuvrer lentement le piston ; on recueılle ainsi un peu de suc ganglionnaire. Laisser I'aiguille en place. Rejeter le liquide dans un tube à hémolyse maıntenu dans la glace. Recommencer l'opération.

- On peut piquer en 2 ou 3 endroits dans le même ganglion. Répéter l'opération sur le ganglion opposé.

- Le liquide récolté constitue l'antigène suspect.

Remarque. Un même bovin peut être ponctionné sans dommage plusieurs jours de suite.

5e TEMPS

\section{EXÉCUTION DU TEST DE PRÉCIPITATION-DIFFUSION EN GÉLOSE}

L'exécution correcte du test de précipitation-diffusion suppose que les temps prélıminaires :

- préparation de la gélose

- préparation et titrage de l'antigène de référence

- préparation ef titrage du sérum précipitant

ont été exécutés et que les résultats s'en sont montrés satisfaisants. 


\section{Matériel.}

1. - Verrerie.

- Boîtes de Petri

- Canne de verre diamètre $5 \mathrm{~mm}$

- Pipettes Pasteur.

2. - Matériel de laboratoire.

- Récipient 11

- Pince de bols

- Crayon à verre

- Aiguille à dissection

- Scie à verre

- Mireur à fond noir

- Feinberg agar cutters (Réf. 1802) ; voir fiche technique no 8.

3. - Matériel divers.

- Carton glacé blanc

- Lampe de poche.

4. - Produits chimiques.

- Crésyl ou antipestique puissant.

5. - Produits biologiques.

- Gélose à précipitation (en tube)

- Sérum de référence

- Antigène positif de référence

- Antigène pour diagnostic.

\section{Technique.}

1er temps. Préparation des boîtes de gélose.

- Faire fondre au bain-marie bouillant 1 tube de 22 contenant la gélose à précipitation (1 tube suffit pour 2 diagnostics).

- Lorsque la gélose est fondue, la couler dans une boîte de Petri de $10 \mathrm{~cm}$ de diamètre. Faire éclater les bulles qui ont pu se former en promenant la flamme d'un bec de gaz sur la gélose ou toucher les bulles avec une baguette très chaude.

- Attendre une heure environ pour que la gélose soit bien solidifiée. On peut à ce moment remettre le couvercle de la boîte de Petri si on le désire.

- On découpe alors des cupules dans la gélose.

II existe deux techniques:

a) On dispose de « Femberg agar cutters ».

Poser l'appareil sur la gélose et enfoncer fermement et d'une manière égale. Le retirer verticalement. Avec une aiguille à dissection, retirer les petits cylindres ainsi découpés dans la gélose. II est inutile d'obturer le fond des cupules ainsi forées à l'aide d'une goutte de gélose fondue.

b) On ne dispose pas de «Cutters».

Préparer à l'avance sur une feuille de papier ou mieux de carton glacé blanc le dessin des cupules: 
chaque cupule a $5 \mathrm{~mm}$ de diamètre et est séparée de $5 \mathrm{~mm}$ des cupules adjacentes; elle a une capacité d'environ $0,10 \mathrm{cc}$.

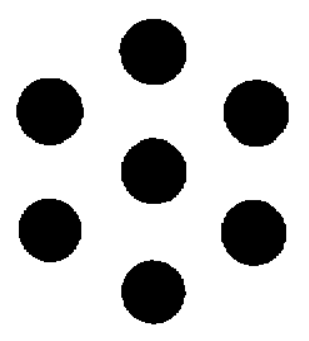

Poser la boite de Petri, couvercle enlevé, sur le dessin. Prendre un fragment de canne de verre, de diamètre intérieur $5 \mathrm{~mm}$, en verre de $0,5 \mathrm{~mm}$ d'épaisseur; en couper une extrémité à la scie pour avoir des bords tranchants et non pas mousses. Découper les cupules une à une. Retirer les cylindres de gélose avec une aiguilie à dissection.

Remarque. Dans les régions sahéliennes (Tchad, Niger, Mali) il y a avantage à couler la gélose dans les boîtes juste avant l'emploi pour éviter leur dessication rapide, surtout en saison sèche. Dans les autres régions, moins chaudes et plus humides, on peut préparer les boîtes à l'avance et les garder dans une boîte de fer blane bien fermée. Elles devront être utilisées dans un délai de un à trois mois selon l'hygroscopie.

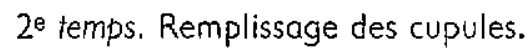

10 Faire décongeler une ampoule de sérum précipitant et une ampoule (ou flacon) d'antigène de référence,

20 A l'aide de pipettes Pasteur (1 pour chaque réoctif) disposer le ou les antigènes suspects dans les cupules ainsi qu'il est indiqué sur le.schéma ; remplir 2 cupules pour chaque antigène (cela n'est parfois pas possible pour les antigènes obtenus par biopsie).

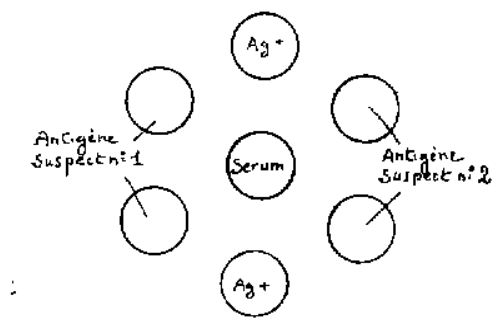

Faire attention de ne faire déborder aucun réactif en dehors des cupules.

Si cela se produisait, absorber' immédiatement la partie en excès avec une lame de papier buvard ou un peu de coton hydrophile, que l'on jette ensuite dans une solution antiseptique.

$3^{\circ}$ Remplir les cupules destinées 'à l'antigène de référence.

Immerger immédiotement après usage les pipettes ayant servi à ta répartition de ces différents antigènes dans une solution antiseptique (eau crésylée à 2 p. 100, par exemple).

40 Remplir la cupule destinée au sérum précipitant.

50 Fermer la boite.

$6^{0}$ Numéroter la boîte et faire au crayon à verre un repère sur la face inférieure. Dessiner sommairement la disposition des cupules sur une feville de papier ; y porter le repère et le numéro de la boîte. Noter les références des antigènes suspects et toutes indications utıles. Conserver ce papier.

3e temps. - Incubation des boîtes.

La vitesse d'apparition de la (ou quelquefois des) ligne (s) de précipitation est fonction de la dis- 
tance séparant les cupules et fonction inverse de la température, aınsi que le montre la figure ci-dessous (fig. 4).

Figure 4

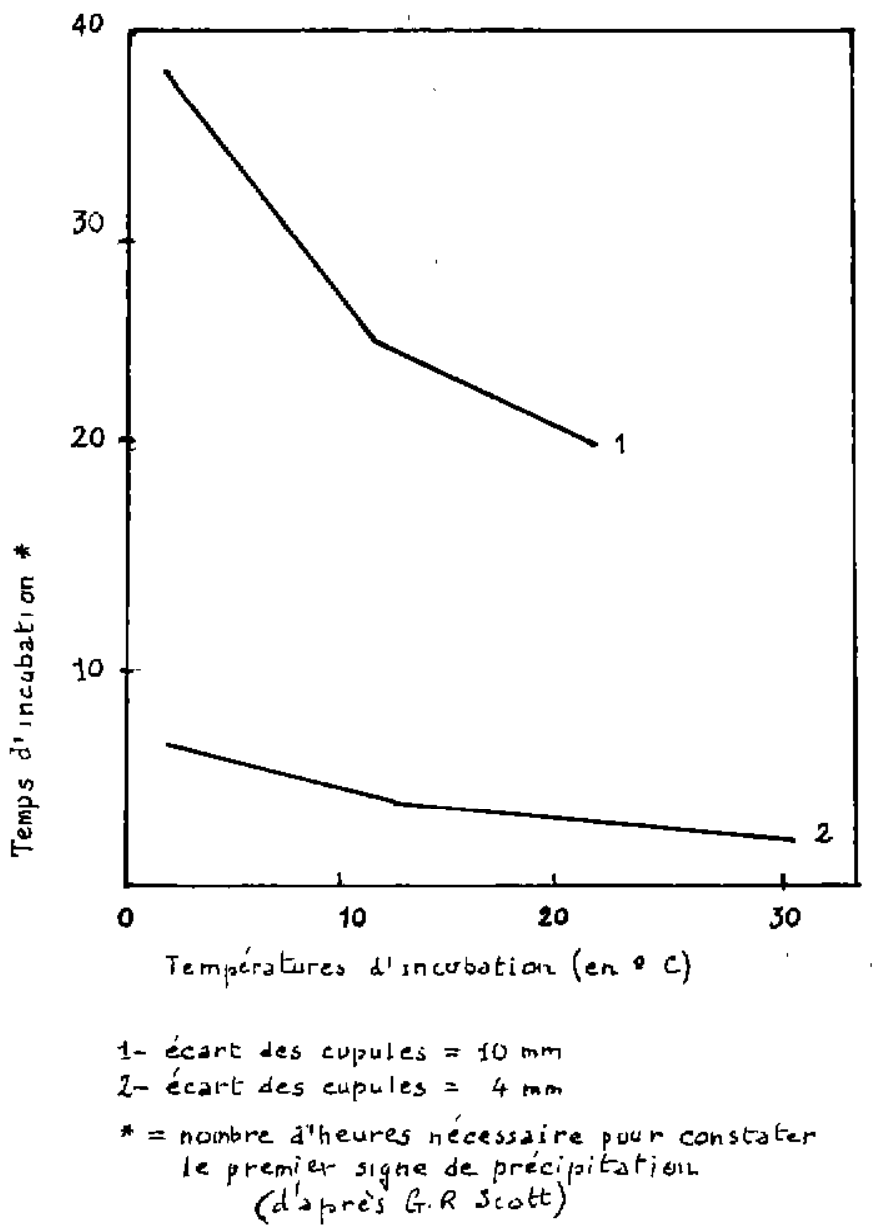

Cependant, il n'y a plus de précipitation à une température supérieure à $30^{\circ} \mathrm{C}$ dans n'importe quel système de cupule; avec le système où les cupules sont distantes de $10 \mathrm{~mm}$ (cas des cupules fattes avec les Feinberg cutters), la précipitation ne se manifeste pas si la température est supérieure à $20^{\circ} \mathrm{C}$.

En effet, le précipıtogène est relativement thermolabile. Le tableau suivant en rend compte.

TABLEAU 1 (d'après G. R. Scott)

\begin{tabular}{|c|c|}
\hline Température (en $\left.{ }^{\circ} \mathrm{C}\right)$ & Validité \\
\hline$-20^{\circ} \mathrm{C}$ & 1 an \\
$10^{\circ}$ & de 96 à 117 heures \\
30 & de 24 à 48 heures \\
40 & de 6 à 18 heures \\
50 & de 11 à 12 minutes \\
& de 3 à 6 minutes \\
\hline
\end{tabular}

Validité d'un précipitogène ayant un titre 50 p. 100 initial. 
En opérant à une température supérieure à $30^{\circ} \mathrm{C}$, on s'expose à trquver négatıf un prélèvement de très faible titre antigénique (ponction-biopsie en début ou en fin de maladie, ou autopsie d'un cadavre au stade terminal de la peste).

Lo figure 5 et le tableau 2 permettront de comprendre le bien fondé de ce rassonnement.

Figure 5

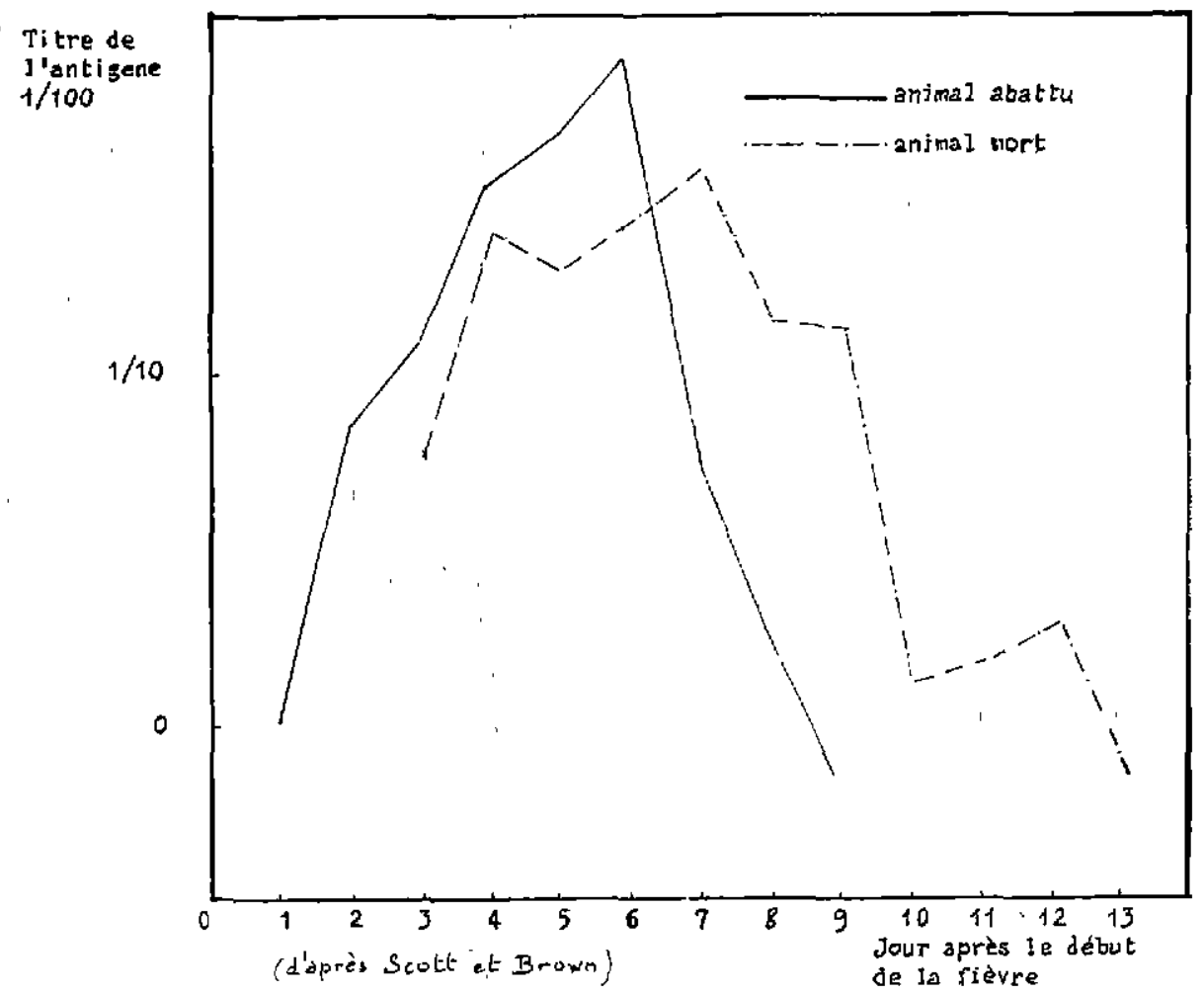

TABLEAU 2 (d'après G. R. Scott)

\begin{tabular}{|c|c|c|}
\hline \multirow{2}{*}{ Temperature en ${ }^{\circ} \mathrm{C}$. } & \multicolumn{2}{|c|}{ Largeur de la zone de diffusion } \\
\hline & $4 \mathrm{~mm}$ & $10 \mathrm{~mm}$ \\
\hline 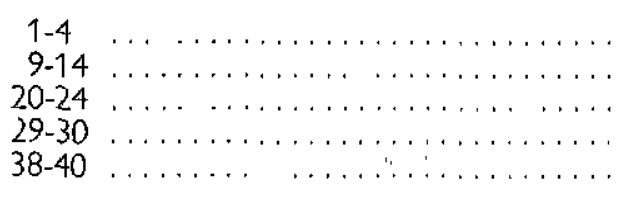 & $\begin{array}{l}6,9 \pm 0,7 \\
4,4 \div 0,4 \\
3,2 \pm 0,2 \\
2,3 \pm 0,2\end{array}$ & $\begin{array}{l}38,4 \div 1,5 \\
24,8 \pm 2,0 \\
20,9 \pm 20,4\end{array}$ \\
\hline
\end{tabular}

Nombre d'heures requises pour l'apparition du premıer sıgne de précipitation.

Les conditions d'incubation seront donc définies selon la température extérieure.

- Si la température moyenne est supérieure à $25^{\circ} \mathrm{C}$. placer les boîtes de gélose dans la partie basse d'un réfrigérateur:

- Sı la température moyenne est inférieure à $20 \circ \mathrm{C}$, on peut laisser les boites sur la paillasse du laboratoire. La vitesse de précipitation sera ainsi augmentẻe. 
En pratique toutefois, ef lorsque le diagnostic ne présente pas une urgence telle qu'il doive être posé à 1 heure près, il est prudent de toujours placer les boîtes de gélose dans le réfrigérateur. Si l'on opère en brousse (ef ceci est tout spécialement vrai pour les régions sahéliennes), on devra placer les boîtes de géiose dons une boîte d̀ glace.

4e temps. Lecture.

- On fera 3 lectures au bout de 12, 24 ef 48 heures, temps conditionné par la température d'incubation (tableau 2).

- Se placer dans une pièce sombre. Tenir la boîte horizontale au-dessus d'un fond noir (carton noir), et l'éclairer obliquement par en dessous avec le pinceau lumineux d'une liampe de poche.

Si l'on a de nombreux examens à faire, réaliser une boîte à éclairage inférieur conforme au modèle ci-dessous. gélose.

- La réaction positive est caractérisée par une bande blanche de précipité à' l'intérieur de la

Elle doit s'être développée entre les cupules contenant l'antigène de référence et le sérum hyperimmun.

Si l'un des antigènes suspects contient le précipitogène bovipestique, une bande similaire se développera entre les cupules qui le contiennent et le sérum. De plus, elle se fondra sans discontinuité dans la bande précédente.

Les bandes de précipitation qui peuvent se produire mais ne se fondent pas avec la bande témoin ou la croisent ne sont pas dues au virus bovipestique mais à d'autres systèmes antigènes-anticorps.

Remorque. II est possibie que deux bandes de précipitation paralièles existent. Cette seconde bande est due à un précipitogène extrêmement thermolabile qui n'est brabituellement pas détecté. La figure cl-dessous donne l'interprétation d'une réaction.

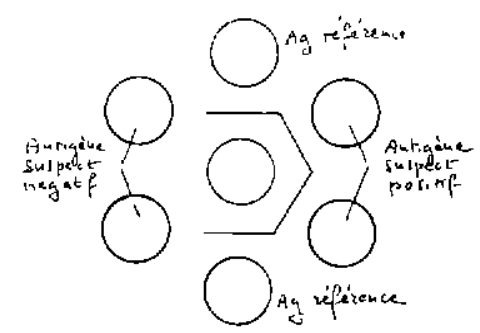

- Noter les résultats par écrit.

- Lorsque toutes les lectures sont terminées, stériliser les boîtes par autoclavage ou par immersion dans l'eau crésylée à 2 p. 100 pendant 24 heures.

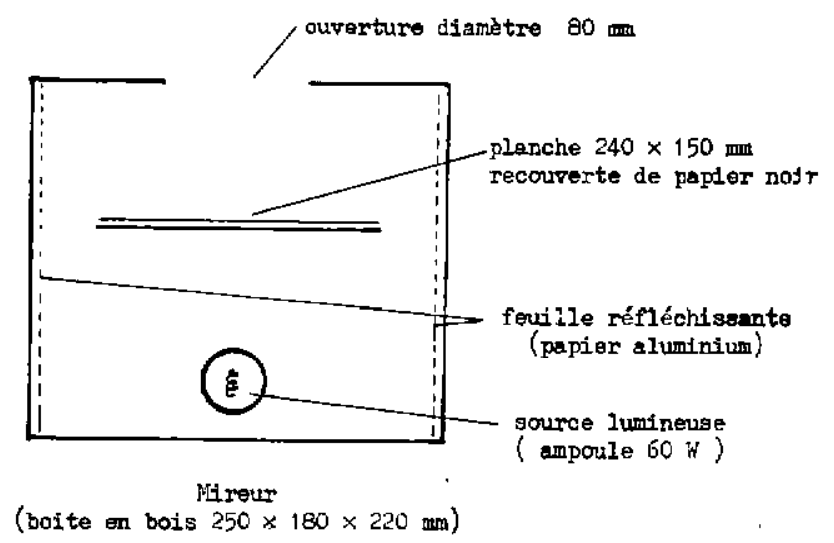


FICHE TECHNIQUE NO 7

\section{MÉTHOdologie des PRÉLÈVEMENTS de SÉRUM POUR DIAGNOSTIC RÉTROSPECTIF DE PESTE BOVINE \\ - (ou pour apprécier la montée des anticorps après vaccination)}

\section{Matériel.}

- Marques à l'oreille numérotées et pince, ou peinture à l'huile ef pinceau, ou ciseaux courbes

- tubes à essais bouchés au coton, stériles

- flacons $20 \mathrm{cc,} \mathrm{avec} \mathrm{bouchon} \mathrm{caoutchouc,} \mathrm{stériles} \mathrm{ou} \mathrm{stérilisés} \mathrm{par} \mathrm{ébullition} \mathrm{prolongée}$

- fil de fer rigide

- lampe à alcool ou autre source de chaleur

- sparadrap, crayon à bille. Alcool à 90" coton

- ciseaux

— aiguilles de fort calibre, stérilisées ou longuement bouillies.

1. Marquer les animaux sur lesquels on désire faire un séro-diagnostic avec une marque à l'oreille numérotée, ou un numéro tracé à la peinture ou aux ciseaux. Numéroter les tubes à essais.

2. Couper les poils sur la gouttière jugulaire. Désinfecter à l'alcool.

3. Prendre une aiguille stérile à ponction intraveineuse, en faisant en sorte de ne pas toucher l'embout. Ponctionner la veine. Faire couler le sang dans un tube à essai, que l'on rebouche aussitôt après. Meftre à température ambiante, en position verticale pendant quelques heures.

4. A l'aide d'un fil de fer rigide, préalablement flambé pour assurer sa stérilité, décoller le caillot de la paroi du tube. Laisser encore exsuder 4 heures à température ordinaire, puis 20 heures au réfrigérateur ou dans la boîte à glace.

5. Rejeter le sérum dans un flacon de $20 \mathrm{cc}$. Boucher. Entourer bouchon et goulot de sparadrap. Numéroter. Congeler si possible.

6. Conserver et expédier sous froid avec une fiche de renseignements.

7. Une vingtaine de jours plus tard, opérer de la même façon sur les mêmes animaux. Inscrire « $2^{e}$ prélèvement» sur les fiacons, en dessous du numéro.

8. Un délai d'un mois après le second envoi est nécessaire au laboratoire avant de donner les résultats. 


\section{FICHE TECHNIQUE No B \\ ADRESSES UTILES}

\section{Réactifs.}

Gélose spécıale Noble (Special Noble Agar) ... Apparell à equ distillée

Appareil à eau déionisé

Chlorure de sodium

Merthiolate (= thimerosal)

Versénate de sodium

\section{Appareils.}

Autoclave

Balance

Centrifugeuse électrique et tubes à centrifuger ò main

Aiguilles à dissection

Feinberg agar cutters $\left(n^{0}\right.$ 1802)

Verrerie

Instruments de chirurgie

Tissue grinders
Difco, c/o O. S. I. 141, rue de Javel, Paris (15e).

- Búchi, Flawil, Saint-Gall, Suisse, en France représenté par Sofranie, 40, rue d'Artols, Paris (8e).

- Jovan, 113, Bd St.-Germain, Paris (6e).

Paris-Labo, 7, rue du Cardinal-Lemoine, Paris (5e).

Prolabo, 12, rue Pelée, Paris (11e).

Serlabo, 26, rue St-Gilles, Paris (3e).

Serlabo, 26, rue St-Gilles, Paris $(3 \mathrm{e})$.

Lequeux, 64, irue Gay-Lussac, Paris ( $\left.5^{\circ}\right)$.

O. S. I. 141, rue de Javel, Paris $\left(15^{\mathrm{e}}\right)$.

Jovan, 113, Bd St-Germain, Paris (6e).

Prolabo, 12, rue Pelée, Paris (11e).

Boubée et Cie, Place St-André des Arts, Paris (6e). Shandon Scientific Co. Ltd, 6, Cromwell Place, London SW 7.

Verrerie Générale, 39, rue des Cloys, Paris (19e). Méca-Vigor, 88, rue de la Folie Méricourt, Paris $(11 \mathrm{e})$.

Kontes glass Co, Vineland, Nj, U. S. A. 


\section{BIBLIOGRAPHIE RESTREINTE}

BOULANGER (P.). - The use of complement fixation test for the demonstration of rinderpest virus In rabbit tissue using rabbit antisera. Canad J. comp. Med. 1957, 21 (11) : 363-9.

COWAN (K. M.). - Cité par SCOTT (G. R.) et BROWN (R. D.) (1961).

CURASSON (G.). - Traité de Pathologie exotique vétérinaire et comparée, $2^{\mathrm{e}}$ édition, Tome 1. Vigot frères, éditeurs. Poris, 1942.

DAUBNEY (Y. R.). - In « Les vaccins contre la peste bovine ». Monographie agricole F. A. O., no 13. Rome, 1949.

HUARD (M.). ANDRE (J.) et FOURNIER (J.). - Essais de titrage des anticorps neutralisant le virus bovipestique. Ann. Inst. Pasteur, 1959, $96: 506$.

JOHNSON (R. H.). - Rinderpest in sheep in Nigerio. Bull. epiz. Dis. Afr., 1957, 5 (4) : 504.

LOWE (H. J.), WILDE (J. K. H.), LEE (R. P.) et STUCHBERY (M. N.). - - J. comp. Path., 1957, $57: 175$.

MONTGOMERY (R. E.). - Cité par BROWN (R. D.) et SCOTT (G. R.). Mucosal disease complex. Vet. Rec. 1957, $69: 916$.

MORNET (P.) et GILBERT(Y.). - Bases et moyens du diagnostic de la peste bovine. Bull. 0. 1. E., 1960. $53: 13$.

MORNET (P.) ORUE (J.) et GILBERT (Y.). - Unicité et plasticité du virus bovipestique. C. R. Acad. SCi., 1956, $242(24): 2886$.

NAKAMURA (J.). - Manuel technique d'application : la réaction de déviation du complément en matière de peste bovine. Monographie de l'O. I. E. Parıs, 1959.

OTTE (E.). - A note on a rinderpest-like disease in the Sudan and in Aethiopia. Bull. epiz. Dis, Afr. 1961,9 (3) : 215.

PLOWRIGHT (W.) et FERRIS (R. D.). - Studies with rinderpest virus in tissue culture. A technique for the detection and titration of virulent virus in cattle tissue. Res. vet. Sci. 1962, 3 (1) : 94-103.

PLOWRIGHT (W). - Some properties of strain of rinderpest virus recently isolated in East Africa. Res. vet. Sci. 1963, 4 (1) : 96.

RECEVEUR (P.). - Note sur certaines affections du cheptel des régions nord-est $d u$ Tchad. La peste bovine expérimentale. Rec. Méd. vét. exo. 1938, 11 (4) : 159-66.

RECEVEUR (P.). - Réflexions sur l'épidémiologie de la peste bovine, en Afrique centrale, Bull. O.I.E. 1951 (janv.-févr.).

RECEVEUR (P.). - L Les animaux sauvages dans la transmission des maladies contagieuses sauf la rage, 22e session du Comité de l'O. I. E. 1954, $42: 213$.

ROBSON (J.), ARNOLD (R. M.), PLOWRIGHT (W.) et SCOTT (G. R.). - The isolation from an eland of a strain of rinderpest virus attenuated for cattle. Bull. epiz. Dis. Afr. 1959, 7, (1) : 97.

SCOTT (G. R.). - Optimal incubation temperature for the rinderpest agar gel double diffusion test Bull, Epiz. Dis. Afr. 1962, $10: 457$.

SCOTT (G. R.). - Bovine hyperimmun serum in the diagnostic of rinderpest. Vet. Rec. 1962, 68 (3) : 308-14. 
SCOTT (G. R.) et BROWN (R. D.). - Rinderpest diagnosis with special reference to the agar gel double diffusion test. Bull. epiz. Dis. Afr. 1961, 9 (2) : 83.

$\operatorname{SCOTT}$ (G. R.) et McDONALD (J.). - Kenya camels and rinderpest. Bull. epiz. Dis. Afr. 1962, 10 (4) : 495.

STONE (S. S.) et MOULTON (W. M.). - A rapid serologic test for rinderpest virus. Am. J. vet. Res. 1961 (86) : 18-22.

THIÉRY (G.). - Influence du type de virus et de l'espèce affectée sur les lésıons de la peste bovine. Rev. Elev. Méd. vét. Pays trop. 1956, 9 (2) : 109-16.

WHITE (G.) ef SCOTT (G. R.), - An indirect gel diffusion precipitation test for the detection of rinderpest antibody in convalescent cattle. Res, vet. Sci. 1960, 1 (3) : 226-9. 